DOE/NASA CONTRACTOR REPORT

DOE/NASA CR-150814

\title{
MASTER
}

\section{SOLAR SYSTEM INSTALLATION AT LOUISVILLE, KENTUCKY (Final Report)}

Prepared from documents furnished by

Rademaker Corporation

Louisville, Kentucky

Under ERDA Contract E(49-18) -2385

Monitored by

NationaI Aeronautics and Space Administration

George C. Marshall Space Flight Center, Alabama 35812

For the U. S. Department of Energy

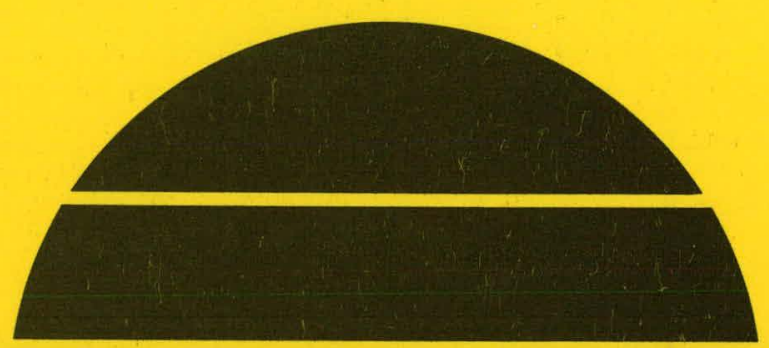

\section{U.S. Department of Energy}




\section{DISCLAIMER}

This report was prepared as an account of work sponsored by an agency of the United States Government. Neither the United States Government nor any agency Thereof, nor any of their employees, makes any warranty, express or implied, or assumes any legal liability or responsibility for the accuracy, completeness, or usefulness of any information, apparatus, product, or process disclosed, or represents that its use would not infringe privately owned rights. Reference herein to any specific commercial product, process, or service by trade name, trademark, manufacturer, or otherwise does not necessarily constitute or imply its endorsement, recommendation, or favoring by the United States Government or any agency thereof. The views and opinions of authors expressed herein do not necessarily state or reflect those of the United States Government or any agency thereof. 


\section{DISCLAIMER}

Portions of this document may be illegible in electronic image products. Images are produced from the best available original document. 
This report was prepared to document work sponsored by the United States Government. Nelther the United States nor 1ts agents the United States Department of Energy, the United States National Aeronautics and Space Administration, nor any federal employees, nor any of their contractors, subcontractors or thelr employees, make any warranty, express or implied, or assume any legal liability or responsibility for the accuracy, completeness, or usefulness of any information, apparatus, product or process disclosed, or represent that its use would not infringe privately owned rights. 


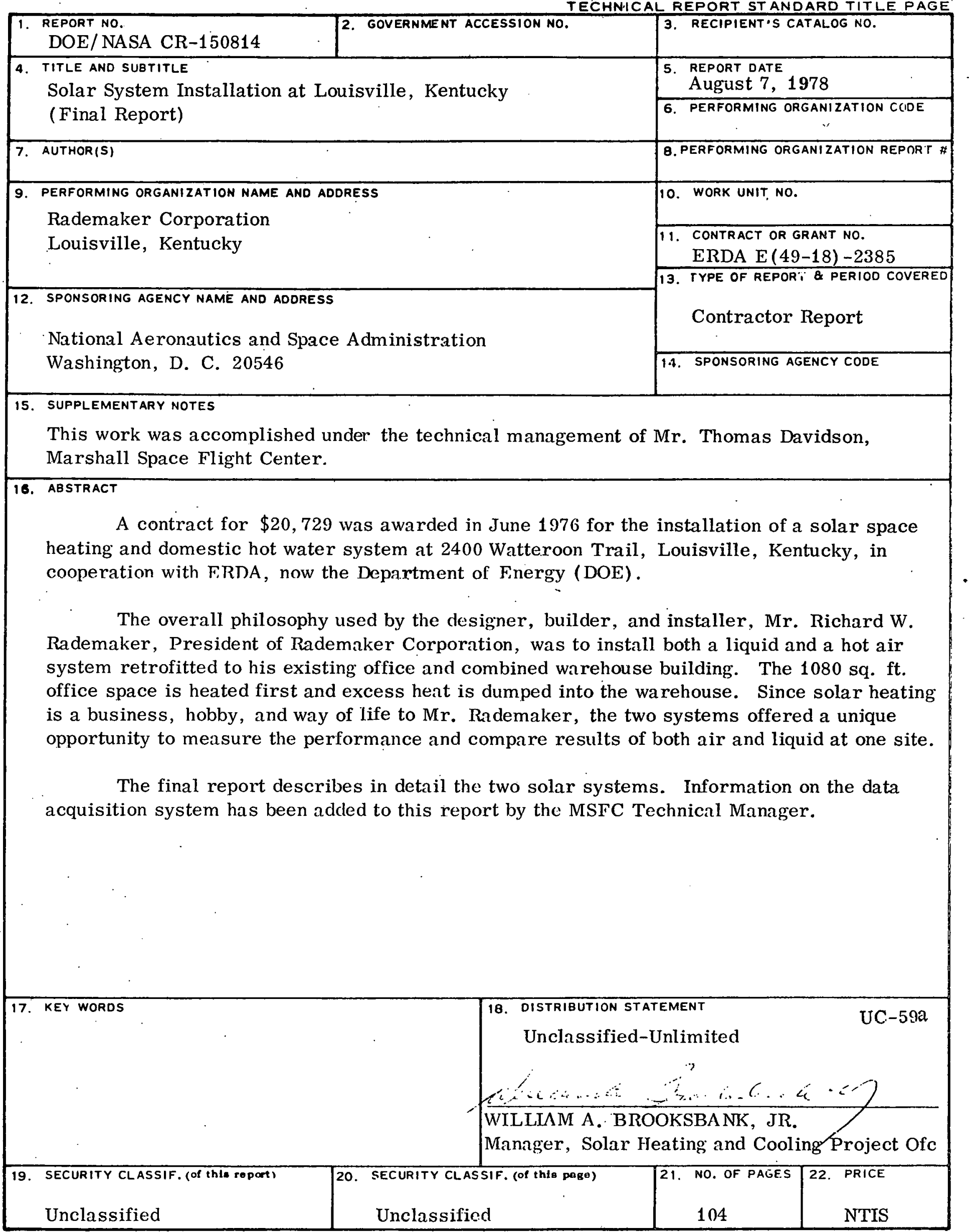


THIS PAGE

\section{WAS INTENTIONALLY LEFT BLANK}


I. General

- System Description and Operation

- Pictures of the Installation 6

- Piping and Duct Schematic (76-241-2) 26

- Elevation and Schematic Piping Layout of Hot Water System (76-241-5)

- Second Floor Plan (76-24l-6) 28

- First Floor Plan (76-241-7) 29

$\begin{array}{ll}\text { II. Controls } & 30\end{array}$

- Control Logi= Narrative (76-241-1) 31

- Controls Schematic (76-241-3) 32

- Controls Wiring Diagram (76-241-4) : 33

III. . Data Acquisition System $\quad$. . 34

- Description $\quad 35$

- Sensor Location Schematic 37

- Temperature Instrumentation Requirements 38

IV. Acceptance Test 43

- Acceptance Test Plan \#1 44

- Acceptance Test Plan \#2 50

- Test Performed for IBM . . 53

V. Interim Performance Criteria Certification $\quad 54$

VI. Updated Key Informatiun frum Original Proposal 57

VII. Major Maintenance and Construction Problems

Encountered and Recommendations 59

VIII. Operation and Maintenance Manual 62

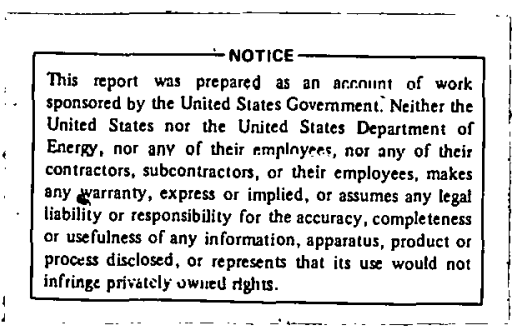

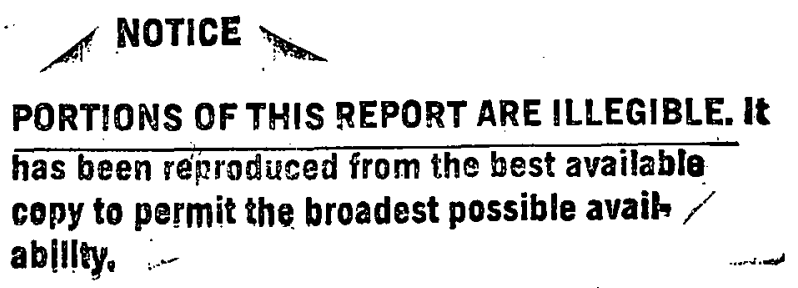

iii 
SECTION I

GENERAL 


\section{A. PROJECT INFORMATION:}

BUILDING: Existing office warehouse built in 1969. Structure is steel Butler Building with masonry front.

CLIMATIC DATA: Latitude $38^{\circ}$. Total annual degree days 4660 ; for January only, 930 . Average winter temperature $42^{\circ}$.

\section{USEFUL HEAT GAIN AVAILABLE FROM COLLECTORS DURING MONTH OF JANUARY: 16,120 BTU per square foot.}

\section{B. BUILDING AND PROJECT DESCRIPTION:}

Occupant of building is Rademaker Corporation, Bluegrass Industrial Park, Louisville, Kentucky. Building was constructed in 1969. It is a Butler Building with a total area of 10,000 square feet. The front portion of the building is office space with 1080 square feet of ground cover. The front wall of the office is brick veneer with relatively large glass area. The solar heating system described herein is for space heating and for heating dumestic hot water. Two systems are employed, one is a liquid heating system employing ethylene glycol through six collectors of 40 square feet each inclined at $53^{\circ}$, facing south. The second system is an air collector system employing ten panels of $191 / 2$ square feet each inclined at $33^{\circ}$, facing south. The liquid system uses a 560 gallon water tank for storage. The air system uses 110 cubic feet of one inch diameter washed river gravel for storage.

The auxiliary energy employed to heat the building is natural gas. The solar heating system is in fact a retrofit to the gas heating system which was installed in the building during its original construction. 


\section{SEQUENCE OF OPERATION:}

The liquid system employs a heat exchanger built into the hot water storage tank which allows ethylene glycol to pump through the collectors when solar radiation is available introducing heat to the stored water. A pump is provided in the stored water loop which will pump water from the storage tank to the hot water coils of either of two air handlers when heat is demanded in the space. Control valves in each of the hot water coil circuits are operated from thermostats to allow water to flow to either or both of the water coils upon demands of their respective thermostats.

Domestic hot water is heated from the glycol circuit by a heat exchanger. The motor operaled valve in the heat exchanger circuit controls the maximum temperature to which the domestic hot water can be heated.

A preheat glycol coil is provided in the perimeter office zone air handler to allow the glycol to be passed through the preheat coil to serve as an economizer within the glycol circuit allowing the glycol to flow in series from the heat exchanger within the storage tank to the preheat coil then back to the collector provided that the storage water temperature has reached a predetermined minimum temperature.

The air collector system employs eight dampers, all of which are motur operated together with a booster fan to introduce the air to the collectors and/or the rock storage bin to the respective air handling system for distribution to the space.

Return air taken from the space is allowed to flow through the collectors as long as radiant heat is avallable then lluough the booster fan and into the respective zone requiring heat. If no zones demand heat, the dampers position themselves to allow flow from the collector through the rnck storage thus charging the rock storage with heat. When heat is not available at the collectors, but is present in the rock storage and is demanded by the space, the booster fan will draw air, counterflow, from the rock storage bin and pass it into the respective zone demanding heat. If excess heat exists and if heat is demanded in the warehouse, heat will be passed from the collectors or from the rock storage bin into the warehouse provided that no heat is demanded within the office space. 


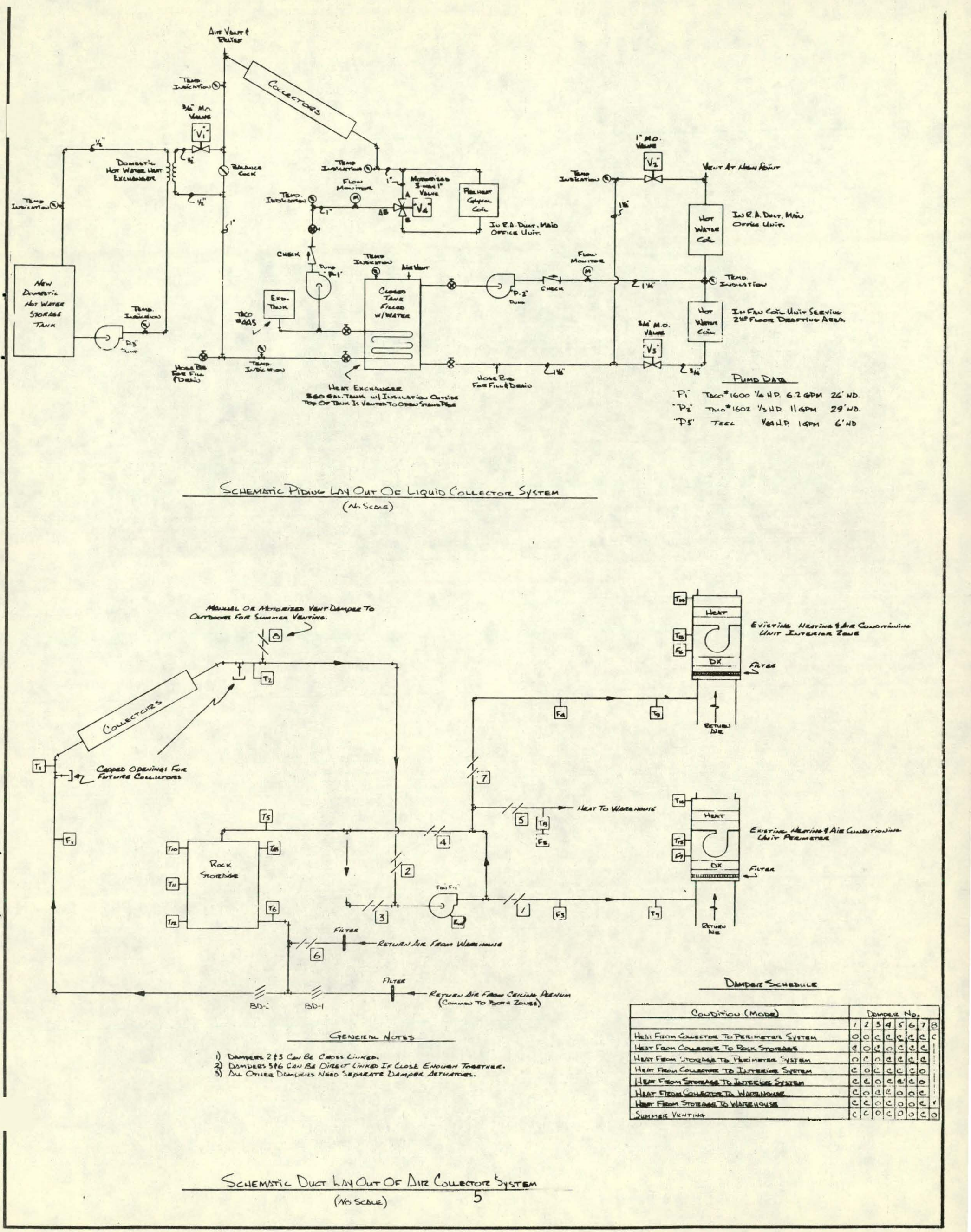




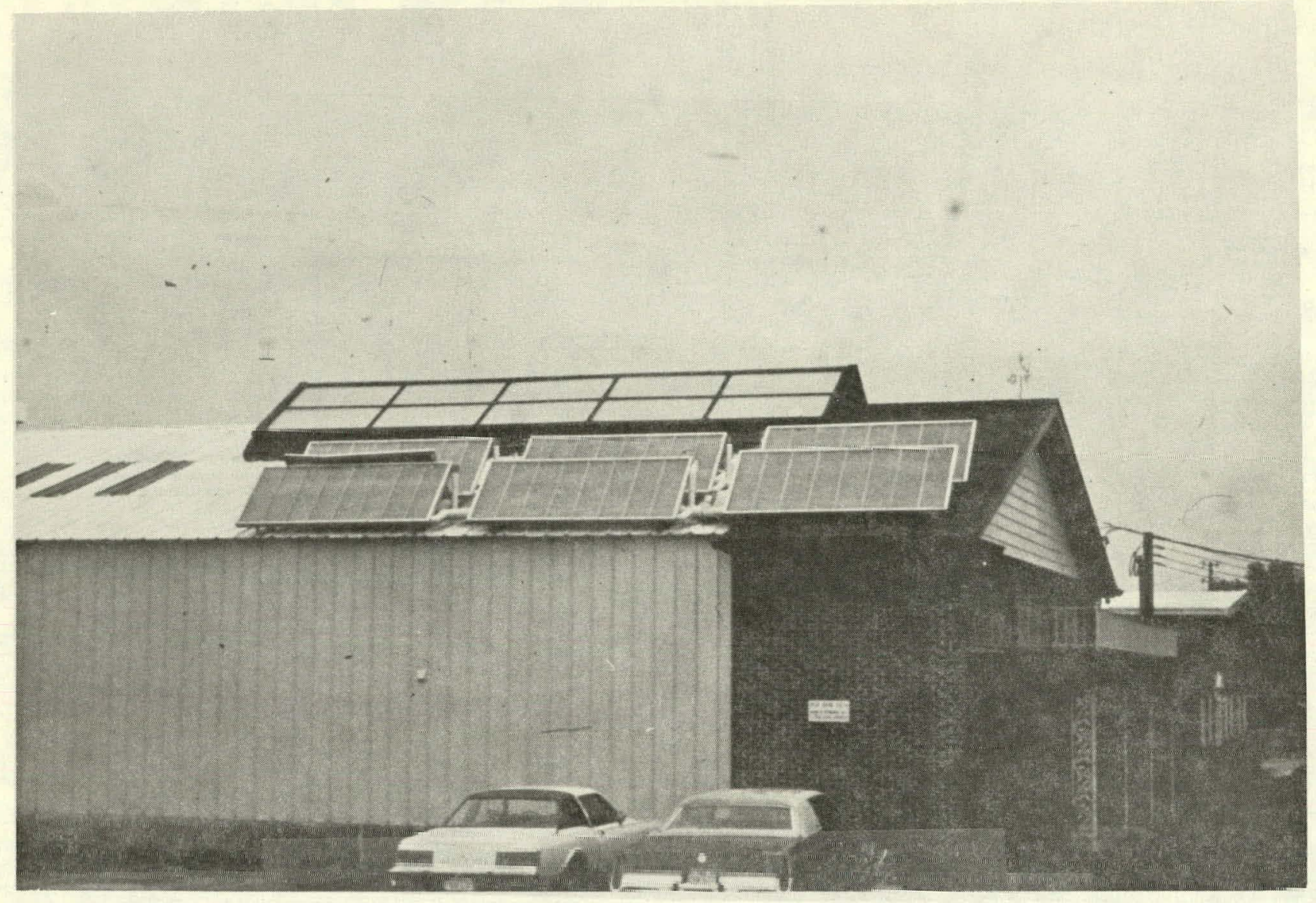

RADCO - Outside View Looking North

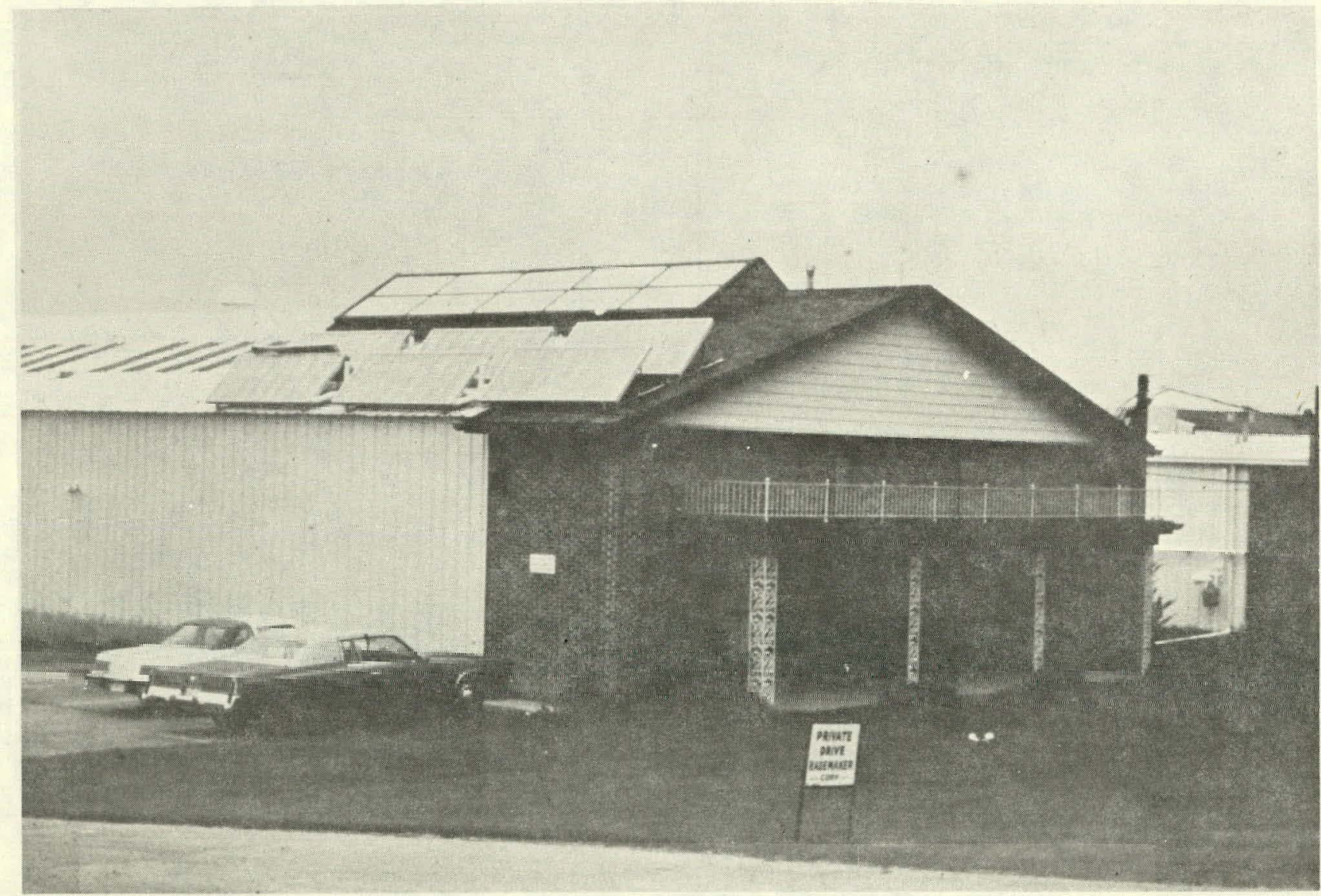

RADCO - Outside View Looking North 


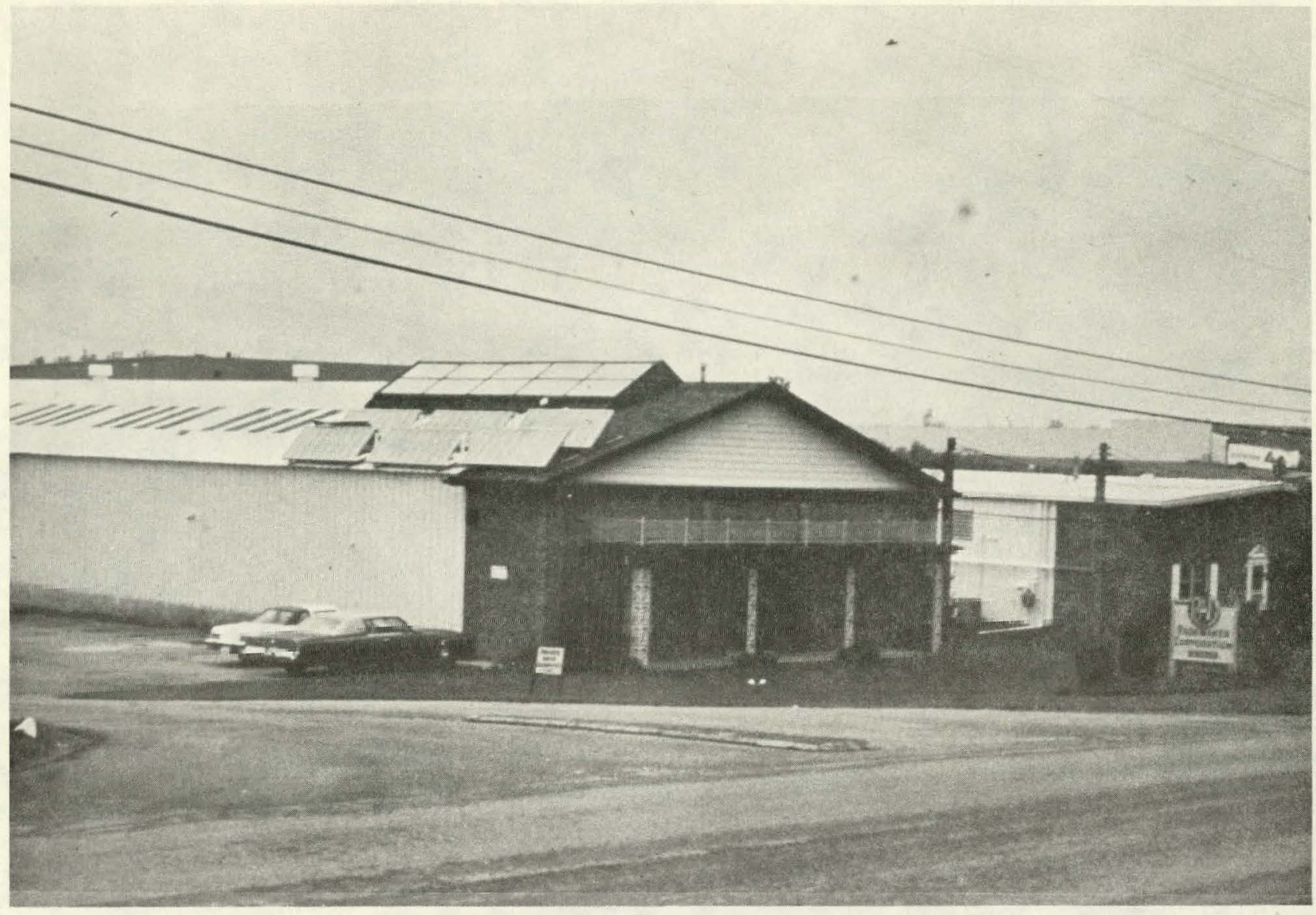

RADCO - Outside View Looking North

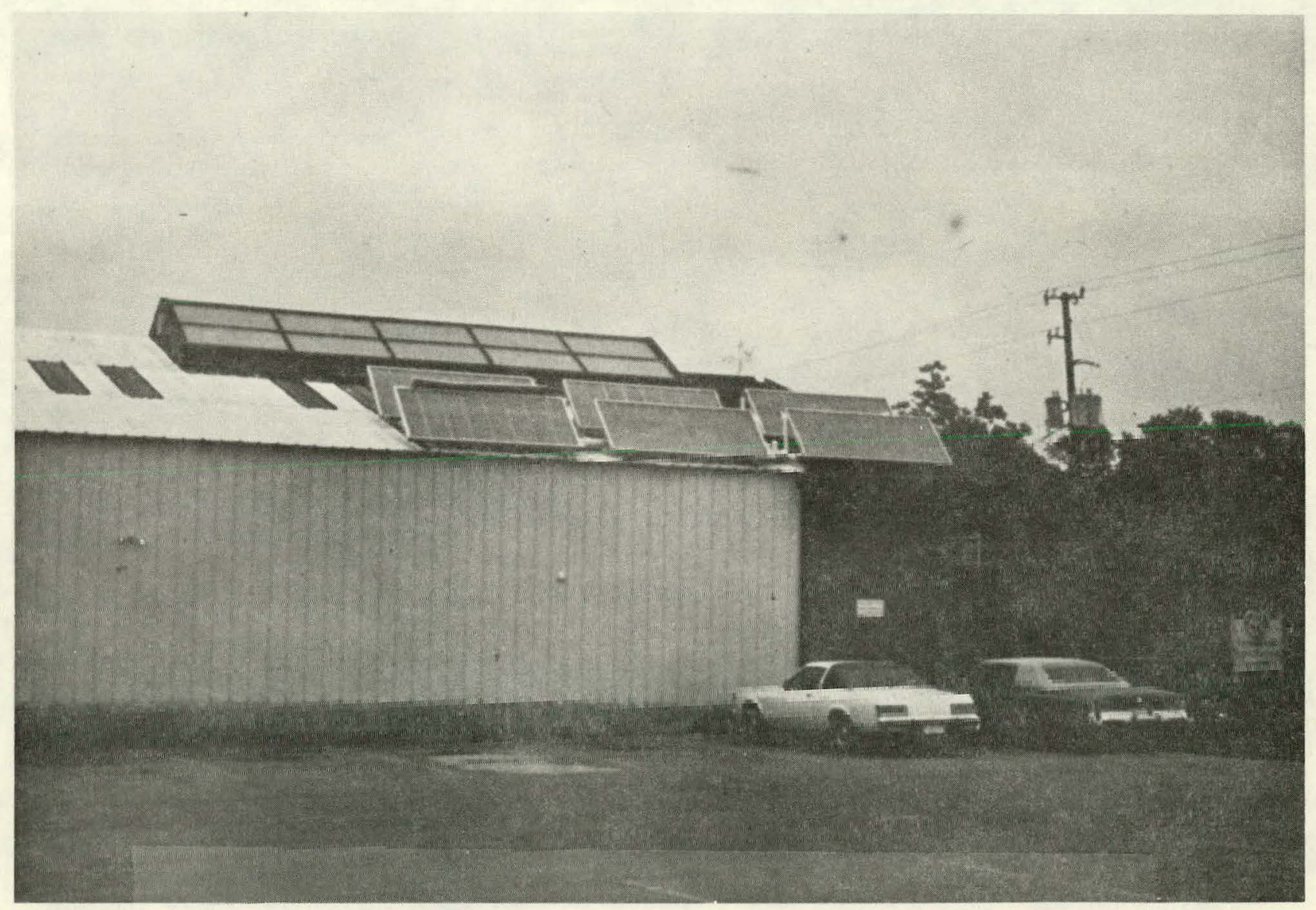

RADCO - Outside View Looking North 


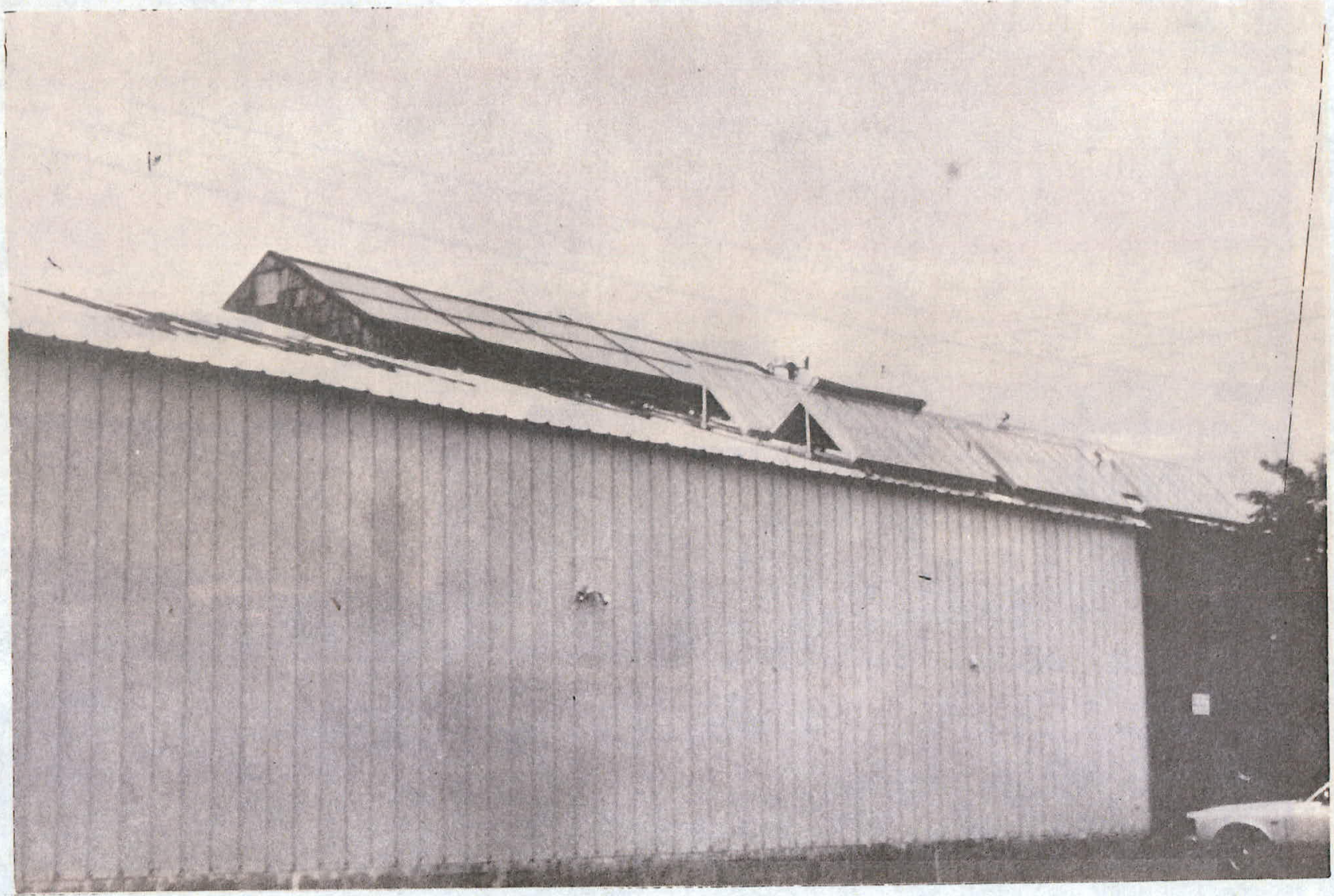

RADCO - Outside View Looking North

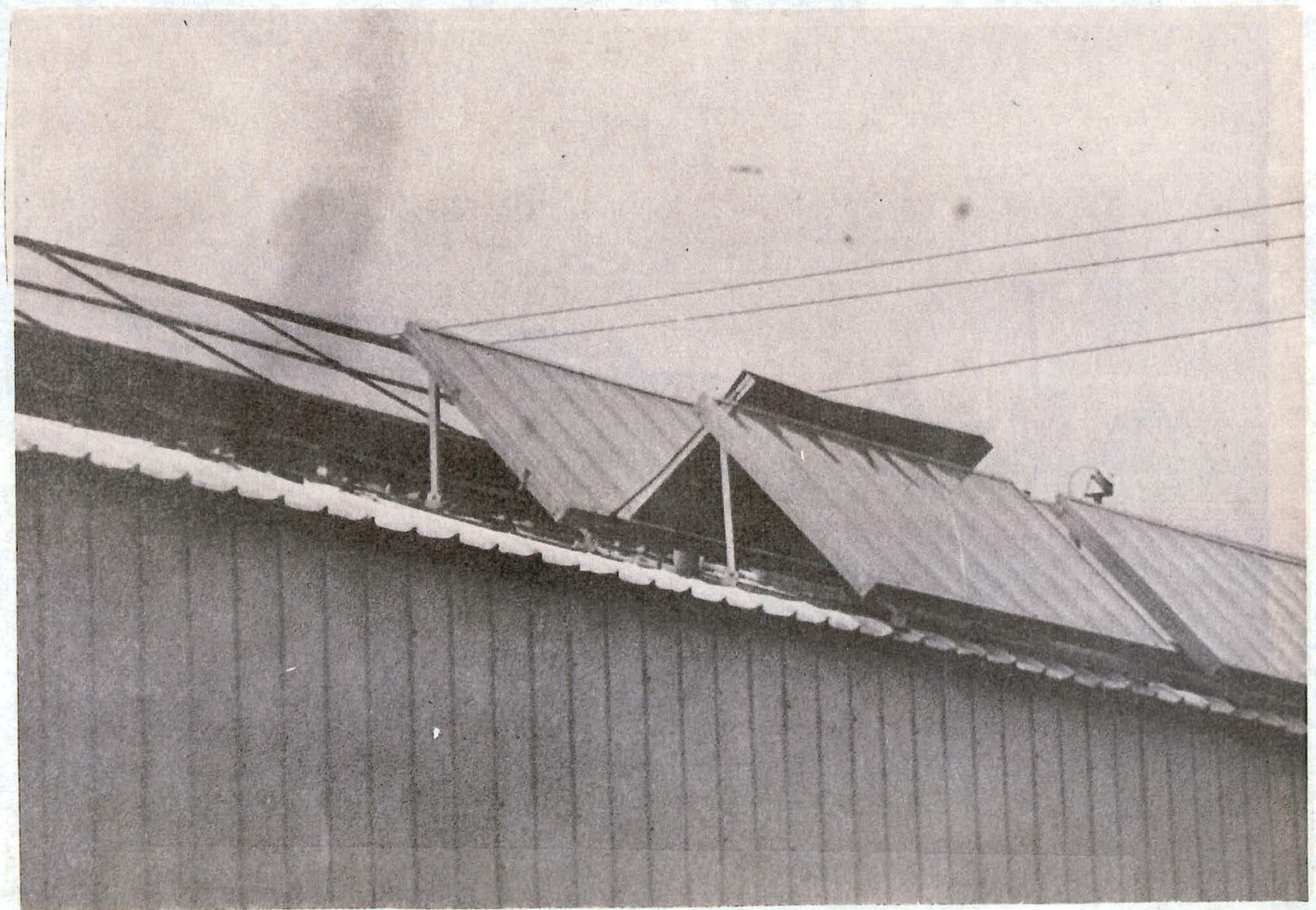




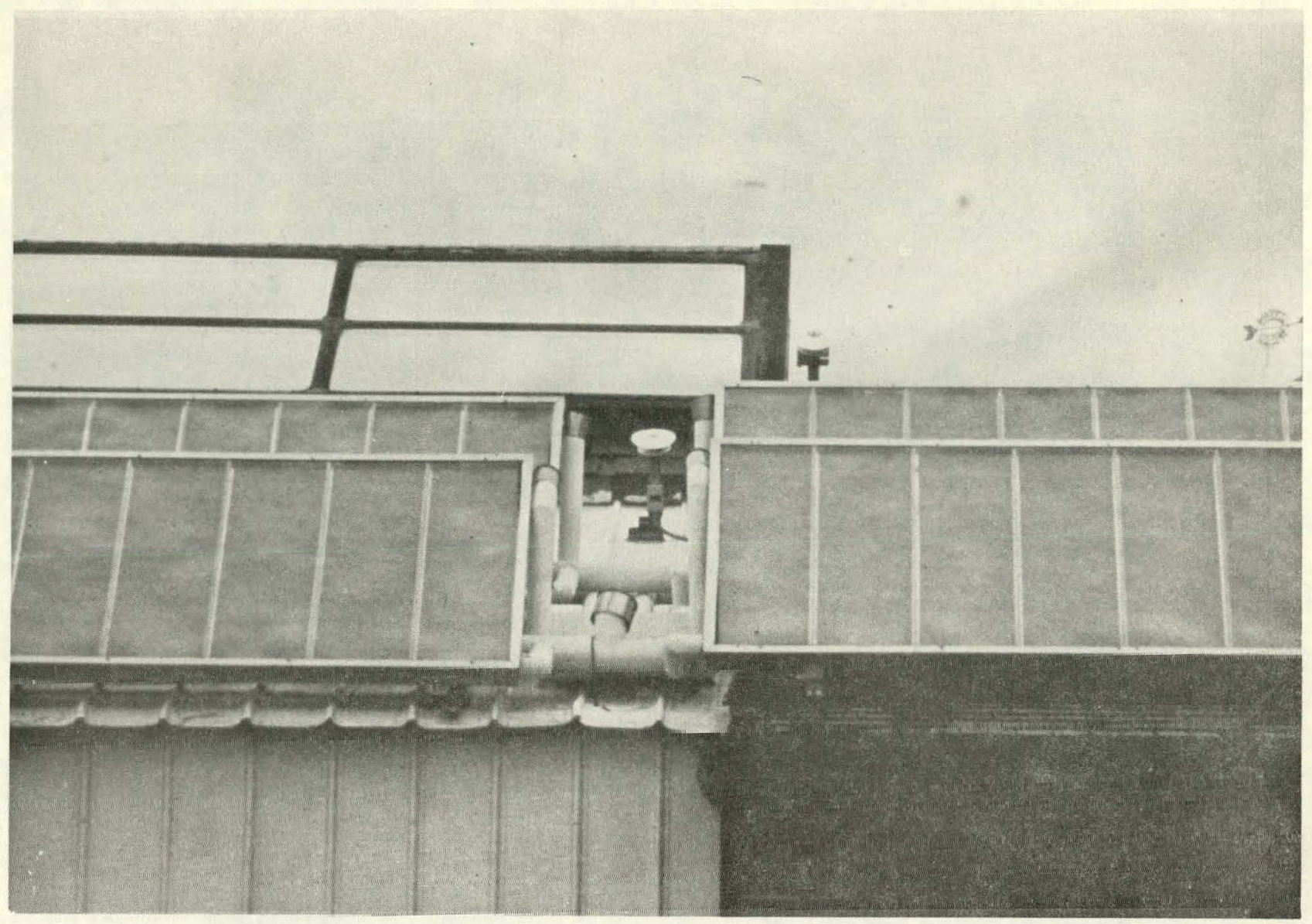

Collectors Close Up

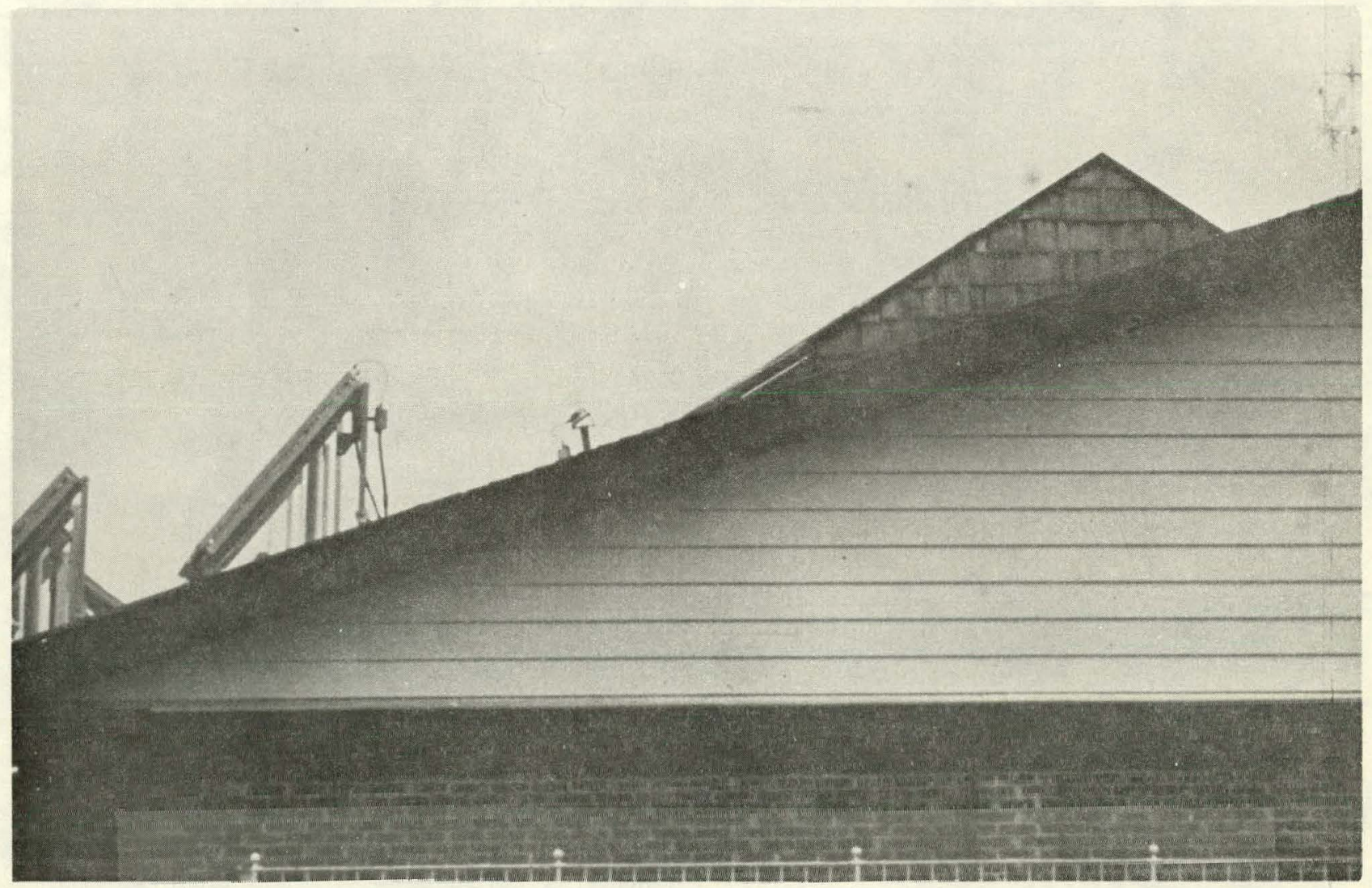

Collectors - Front of Building Looking West 


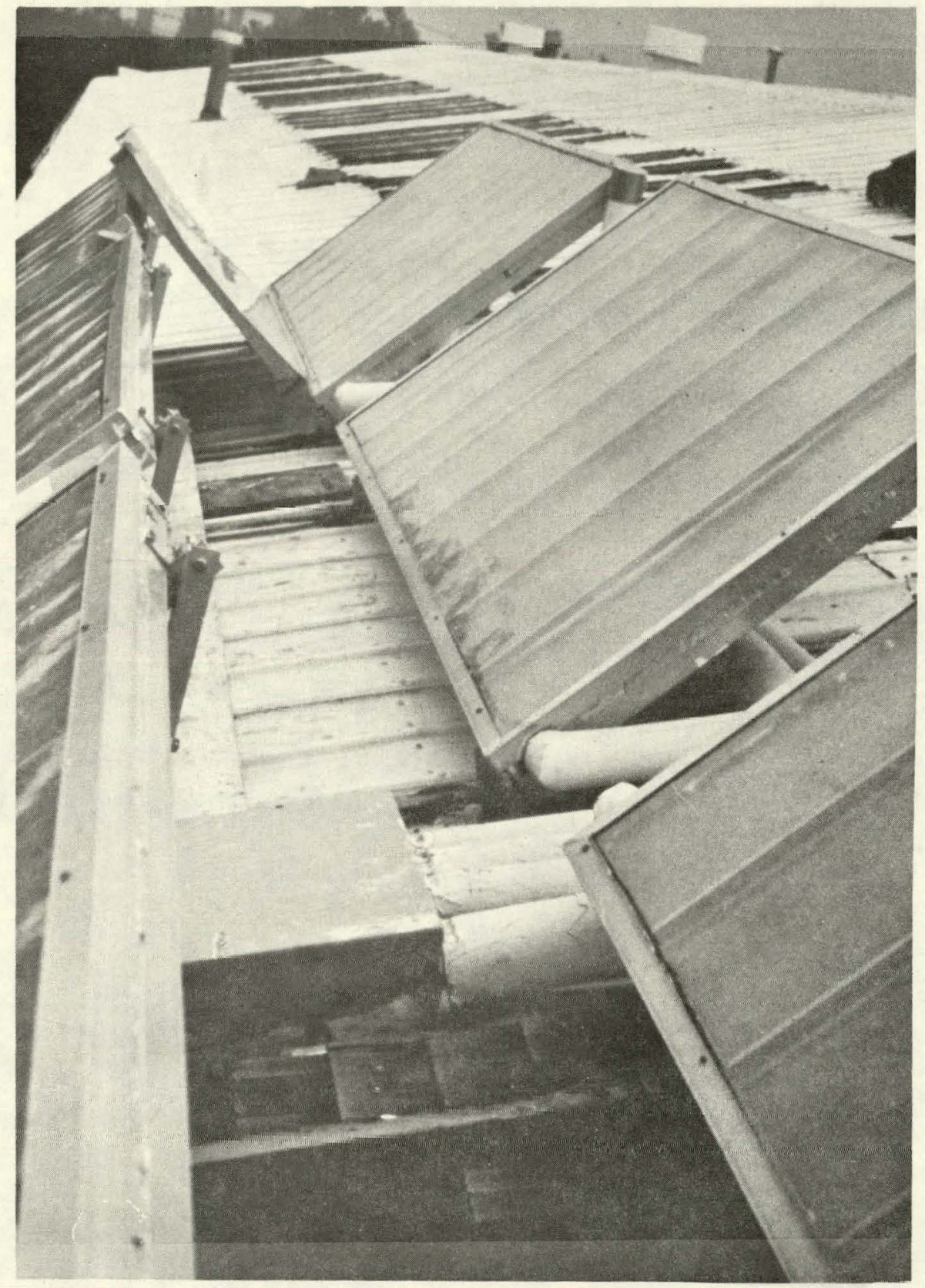

Collectors on Roof Looking West 


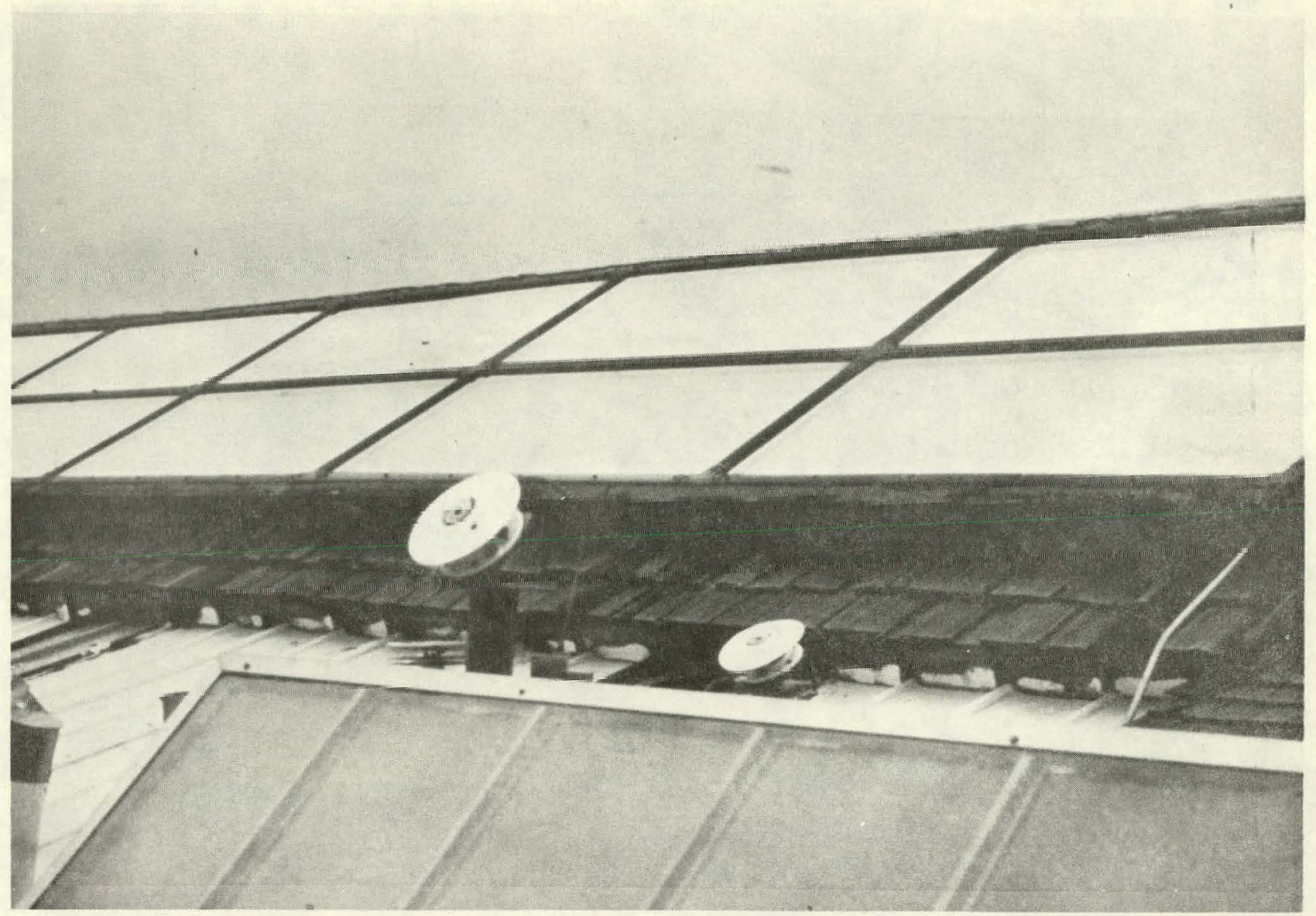

Roof View of Air Collectors

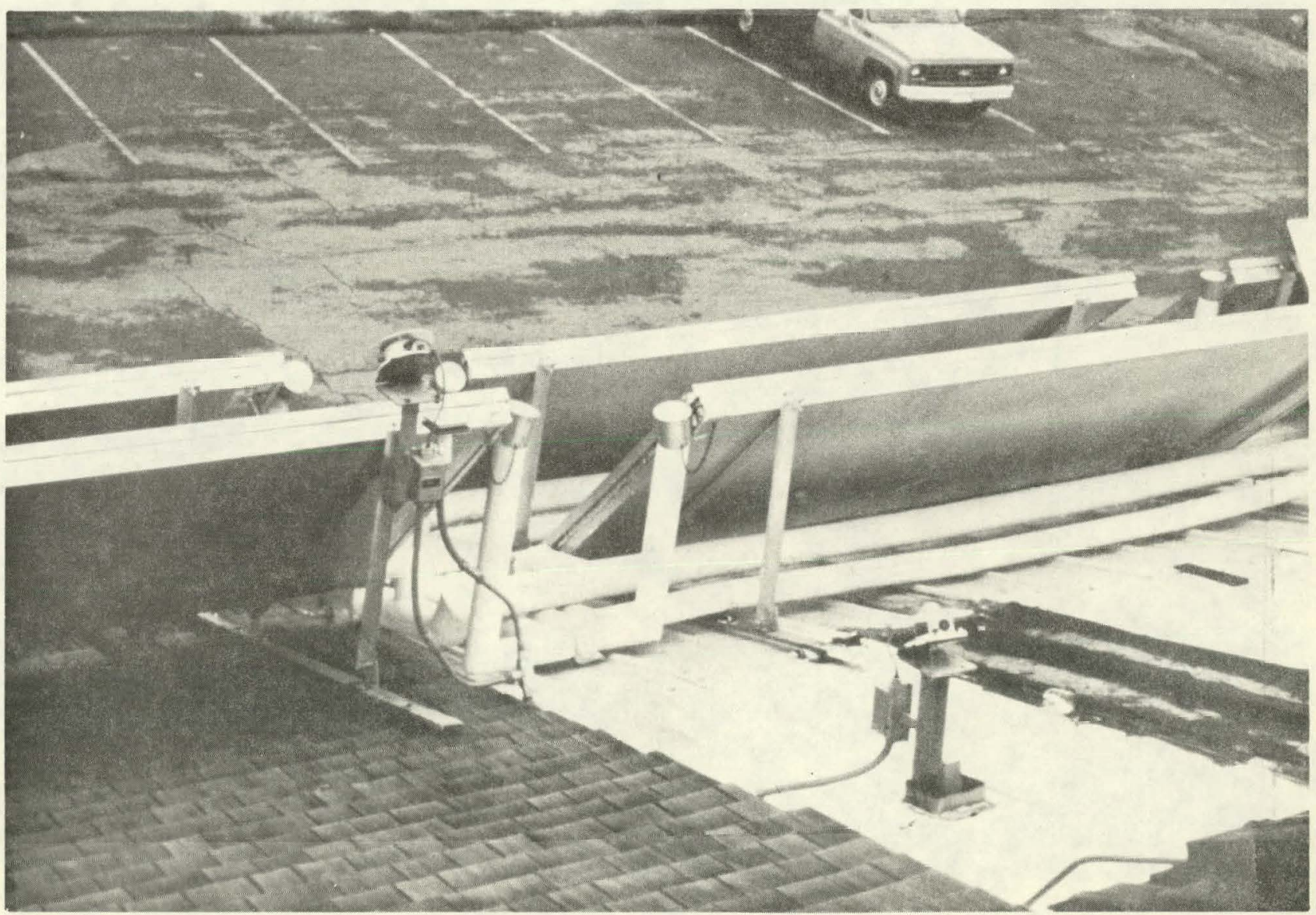

Back View of Liquid Collectors 


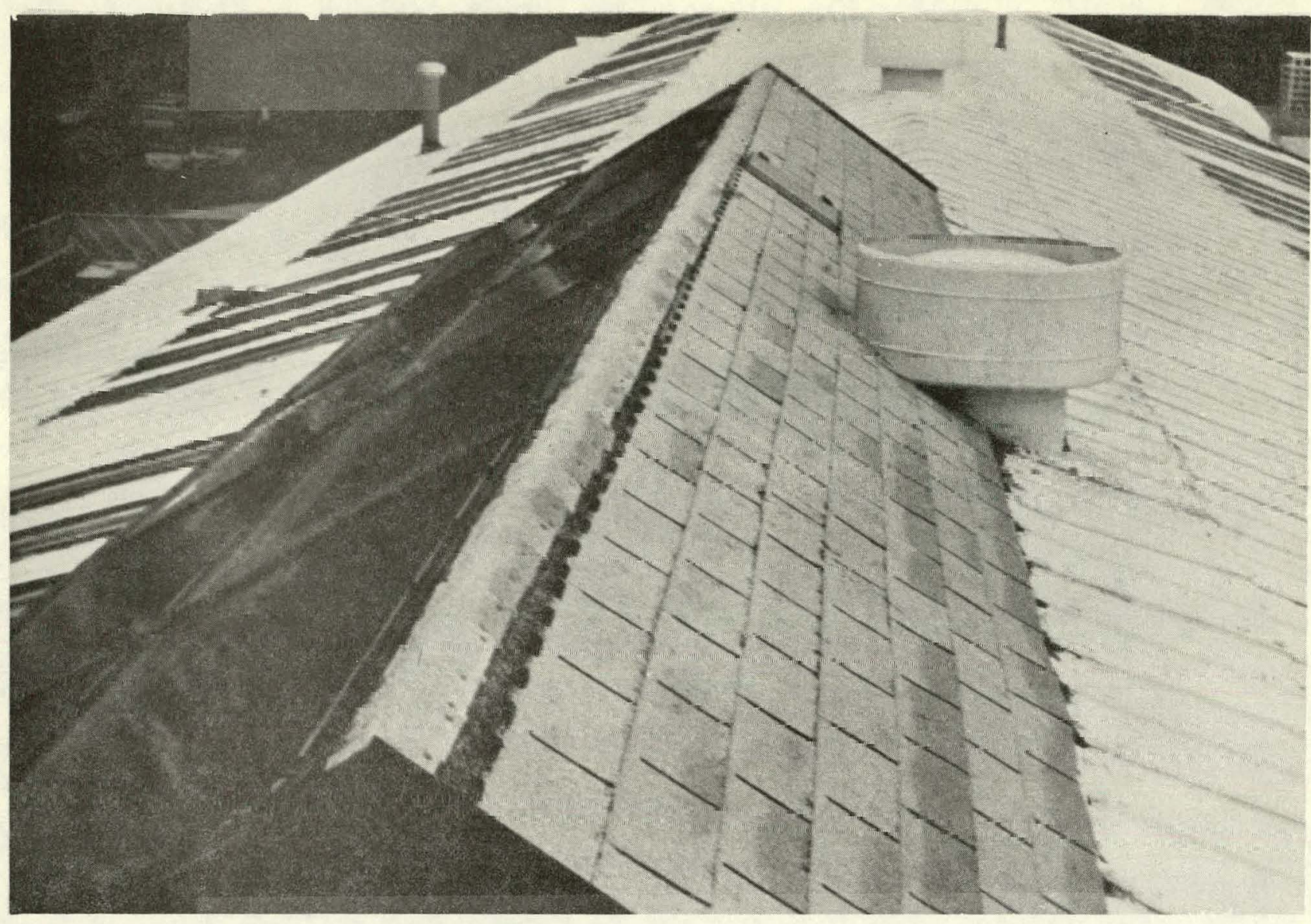

End View of Air Collectors Looking W. S. W.

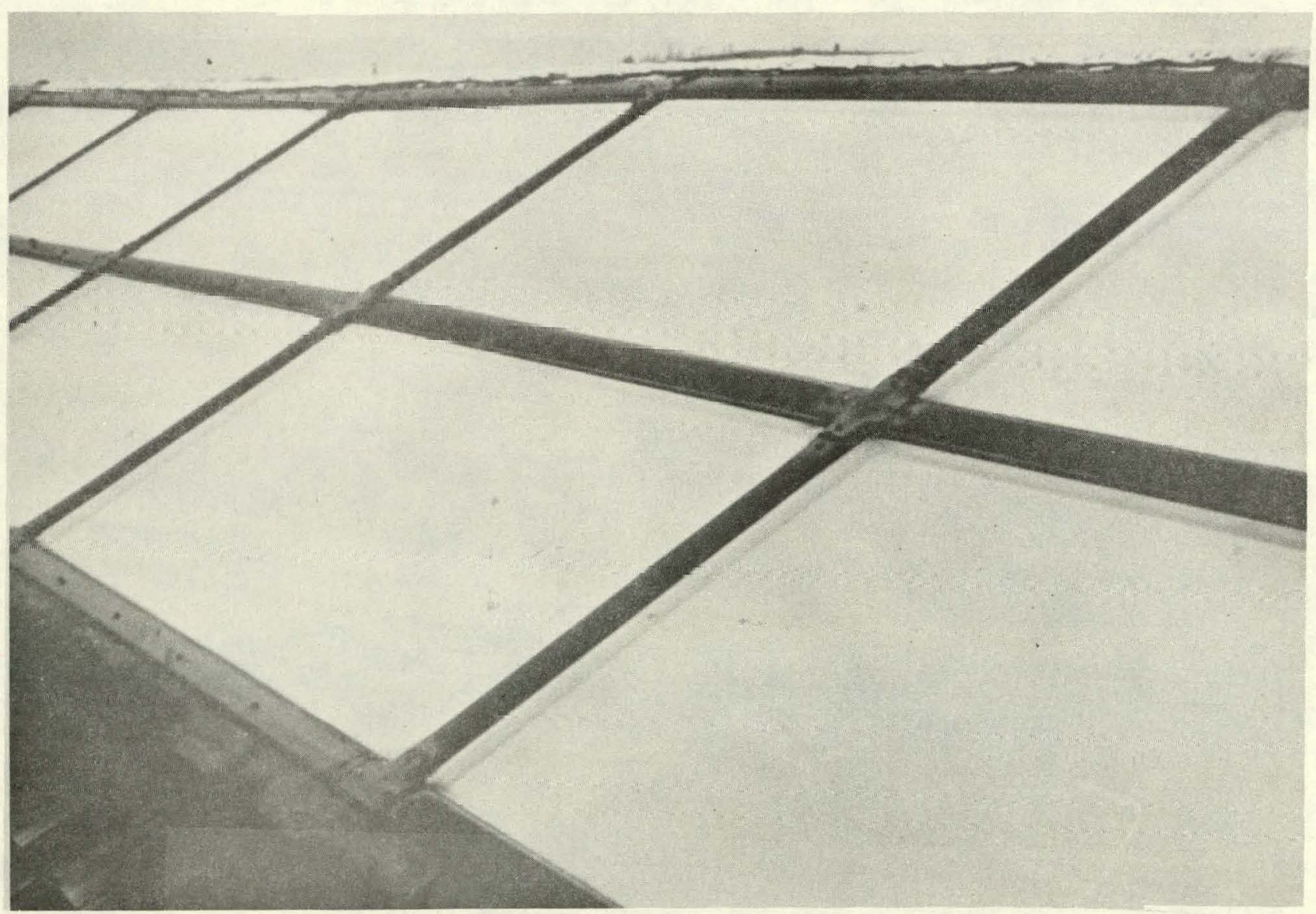

Close Up of Air Collectors 


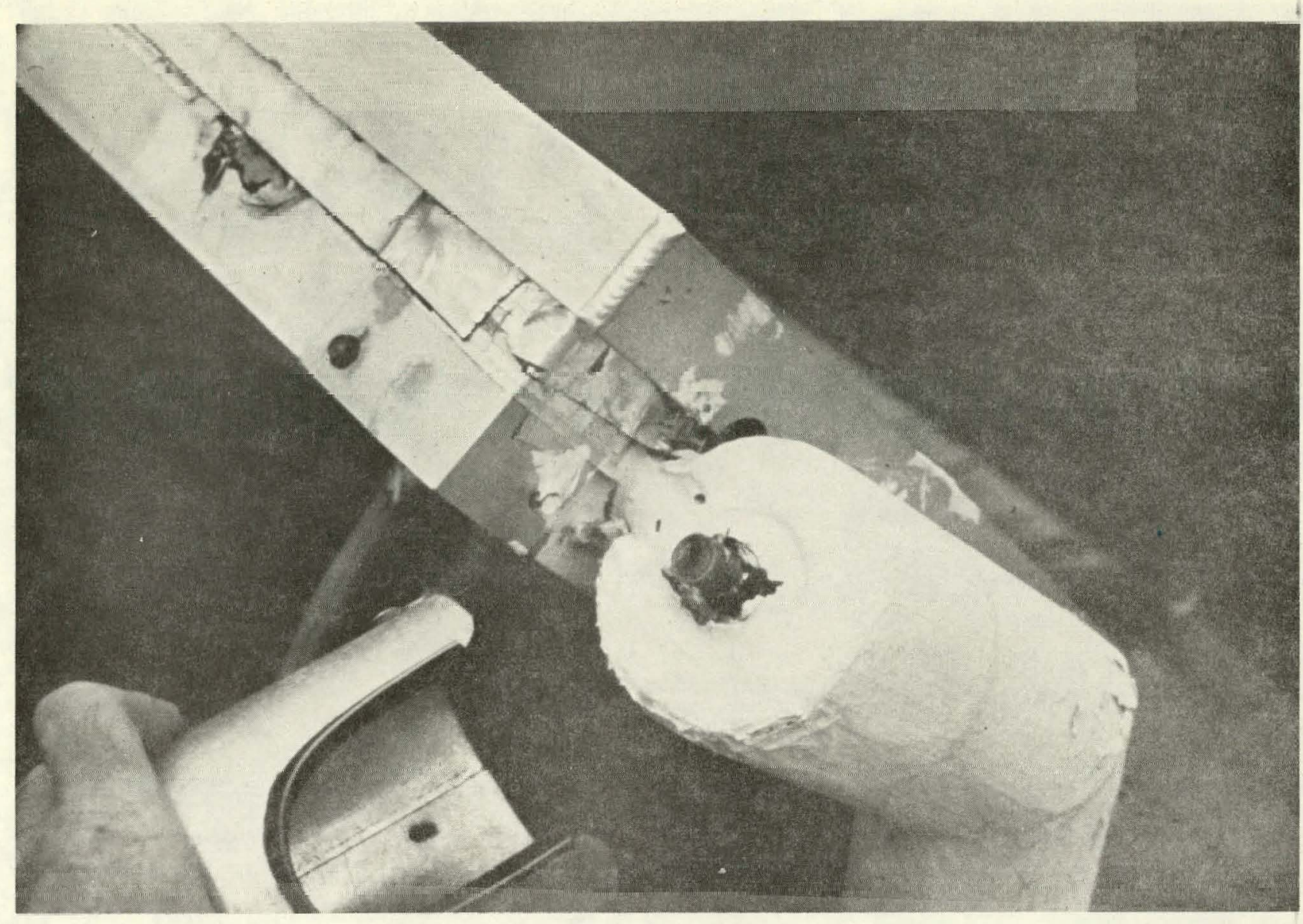

Air Vent on Collector

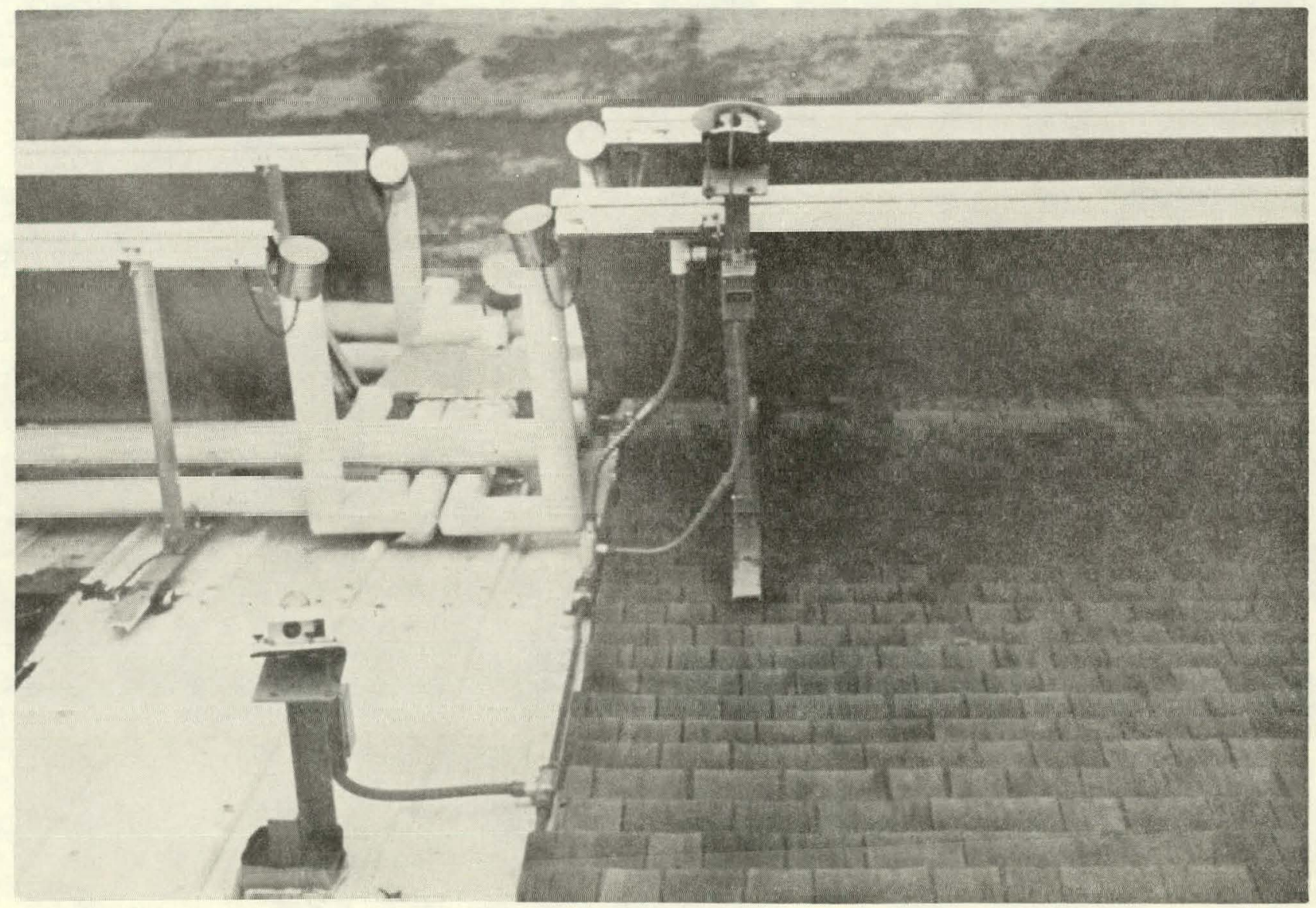

Back View on Liquid Collectors 


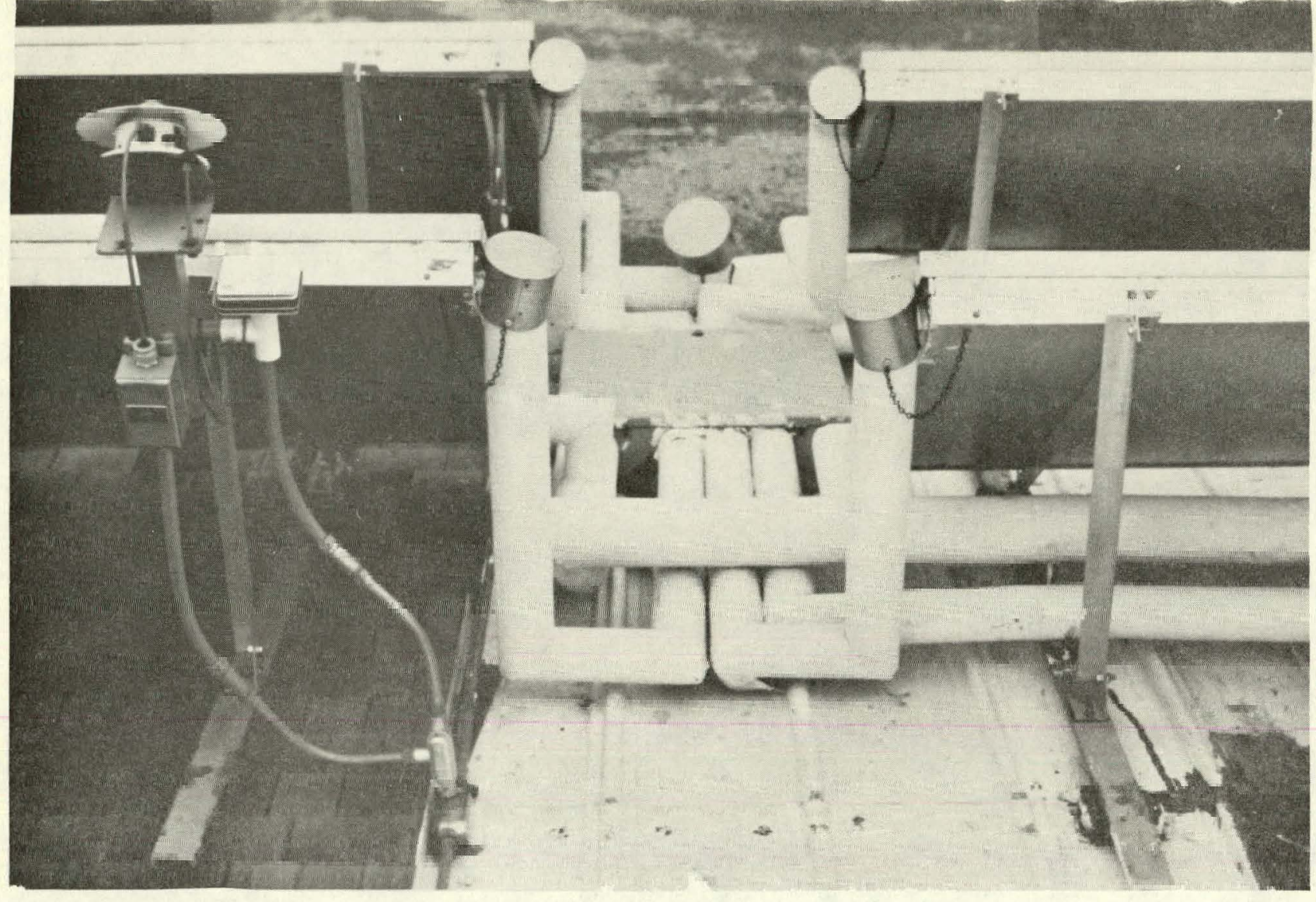

Back View of Liquid Collectors

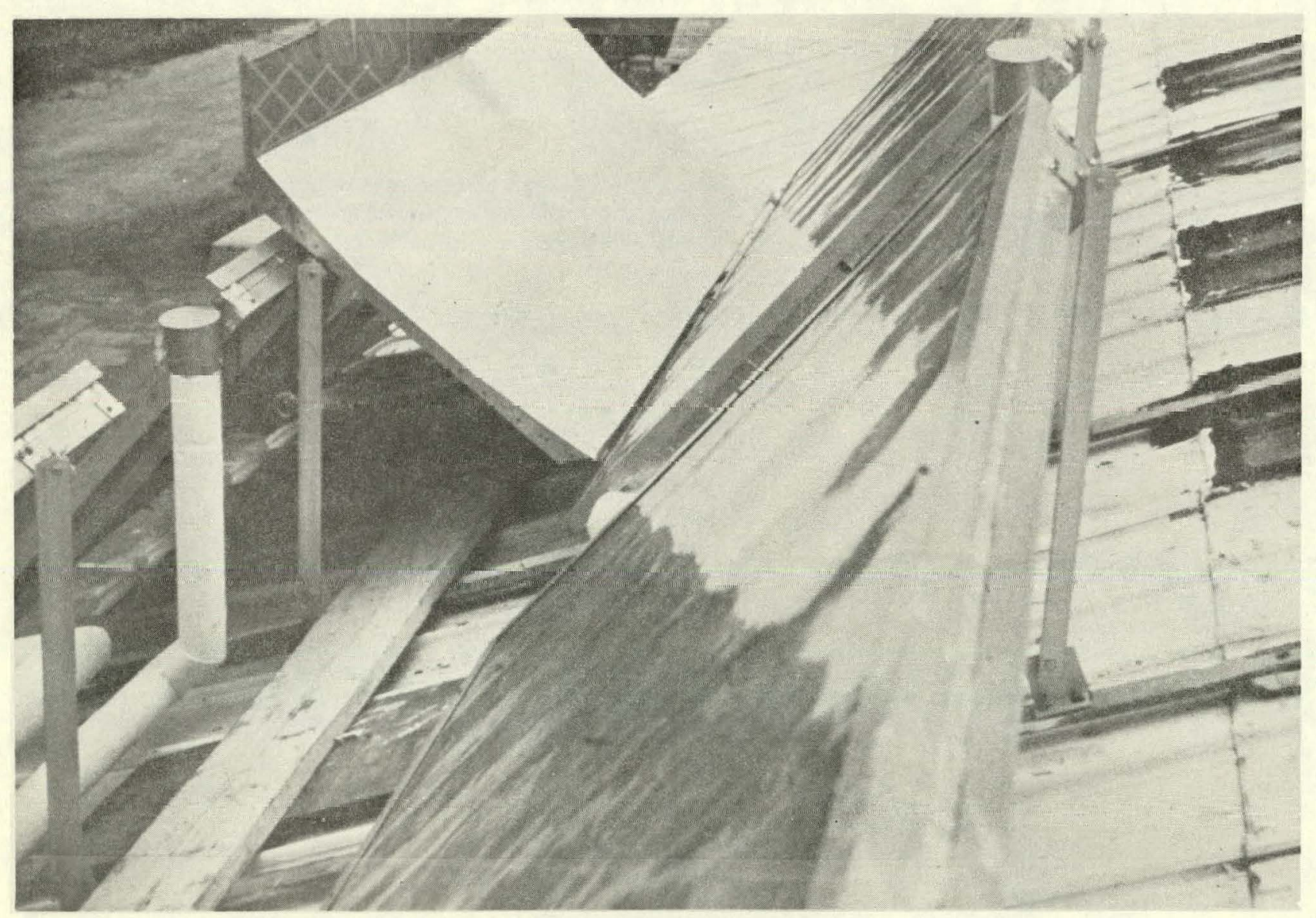

Close Up of Reflector Looking West 


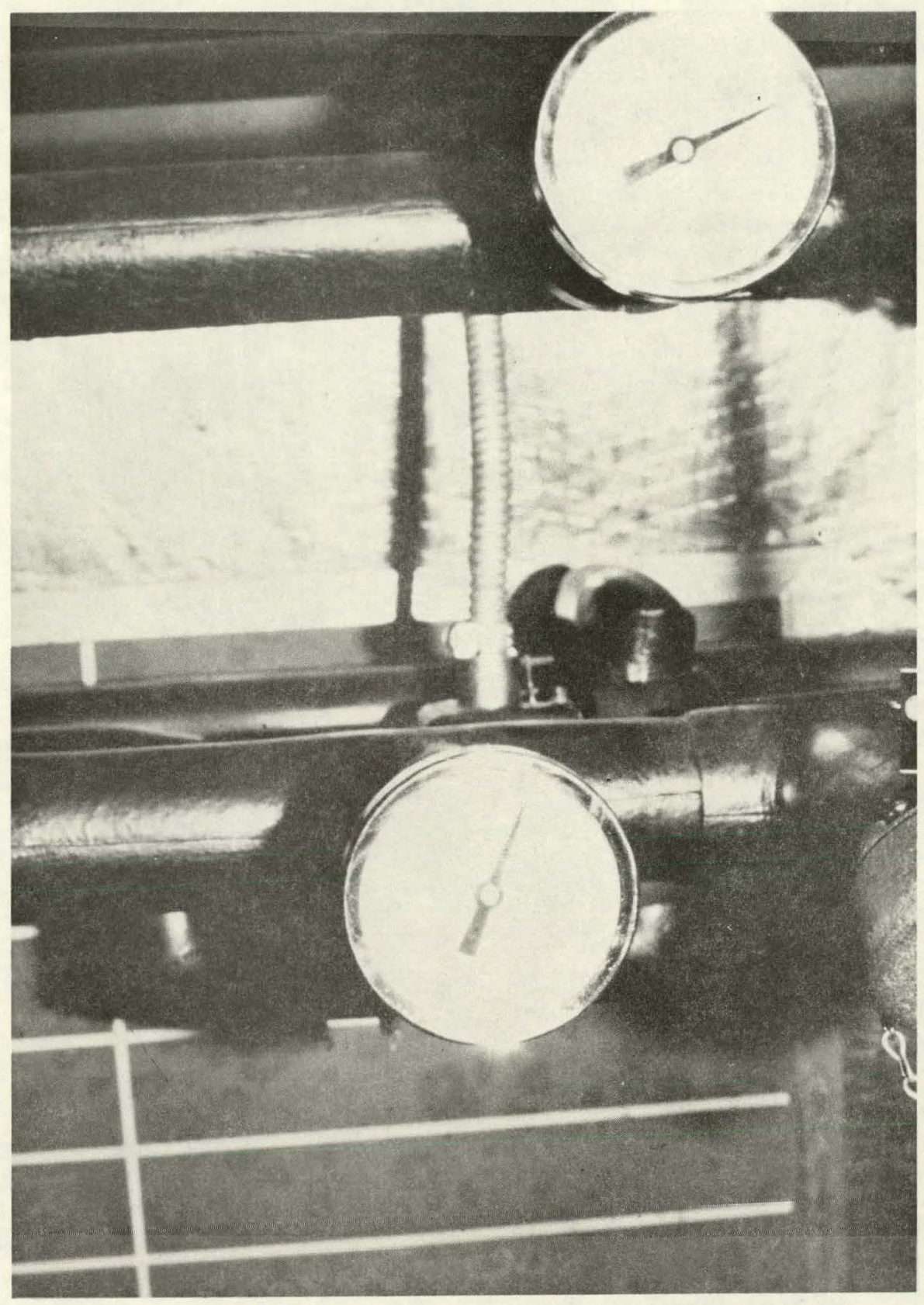

Temperature Gauges Showing Glycol Discharge Temperature - Upper Gauge with Reflector 


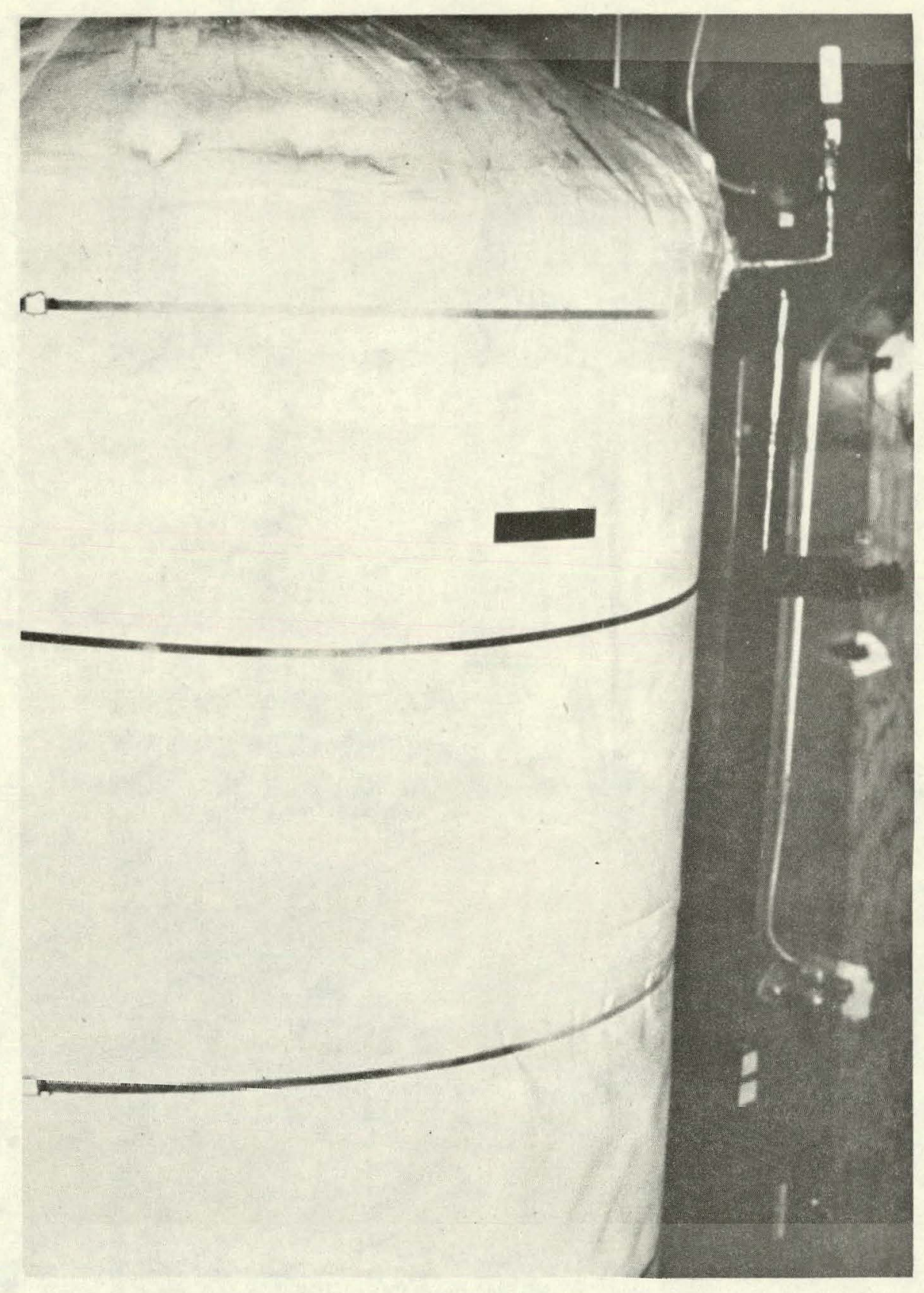

Water Storage Tank - 560 Gallon 


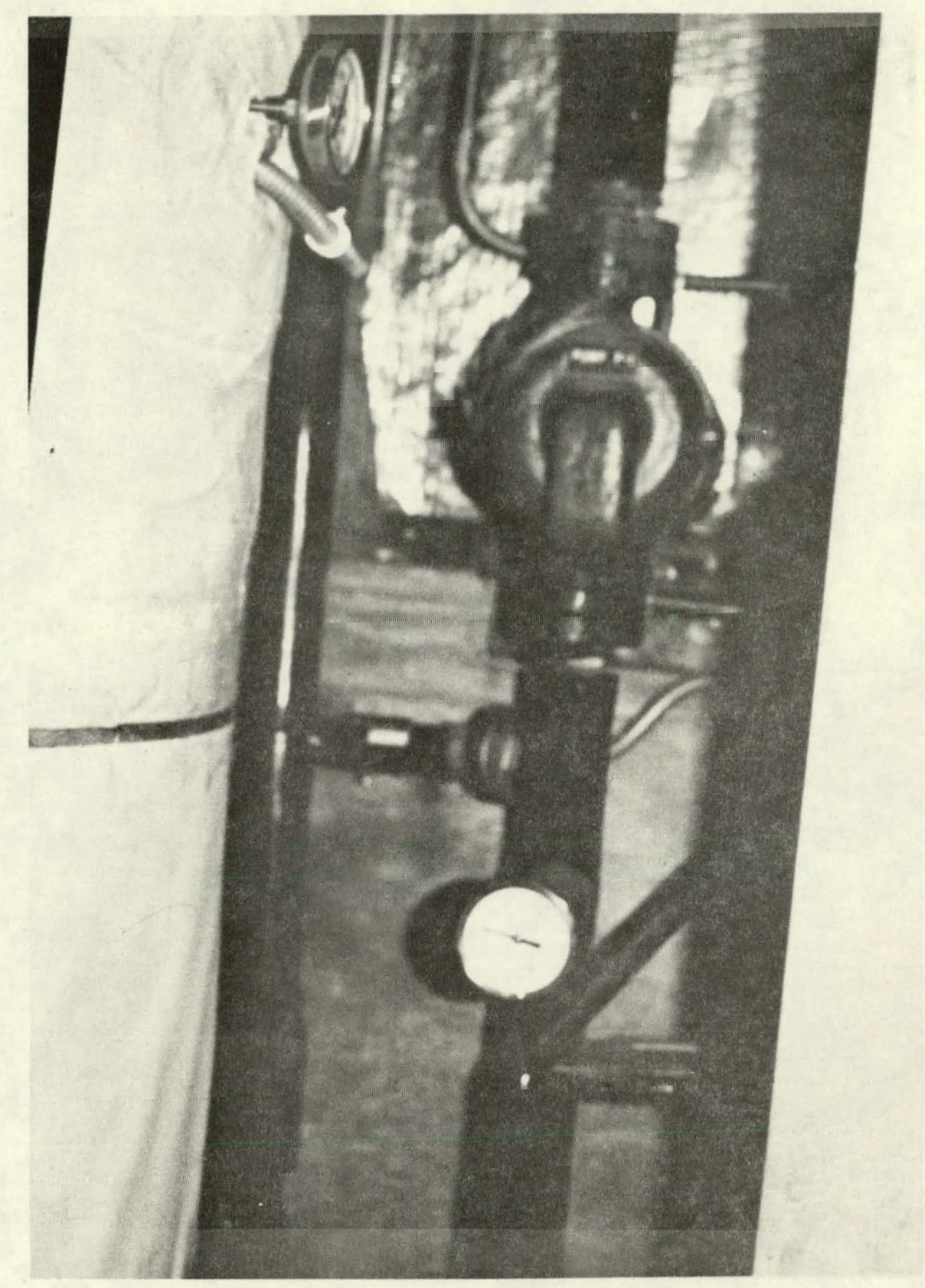

Glycol Pump P-1 \& Pressure Gauge 


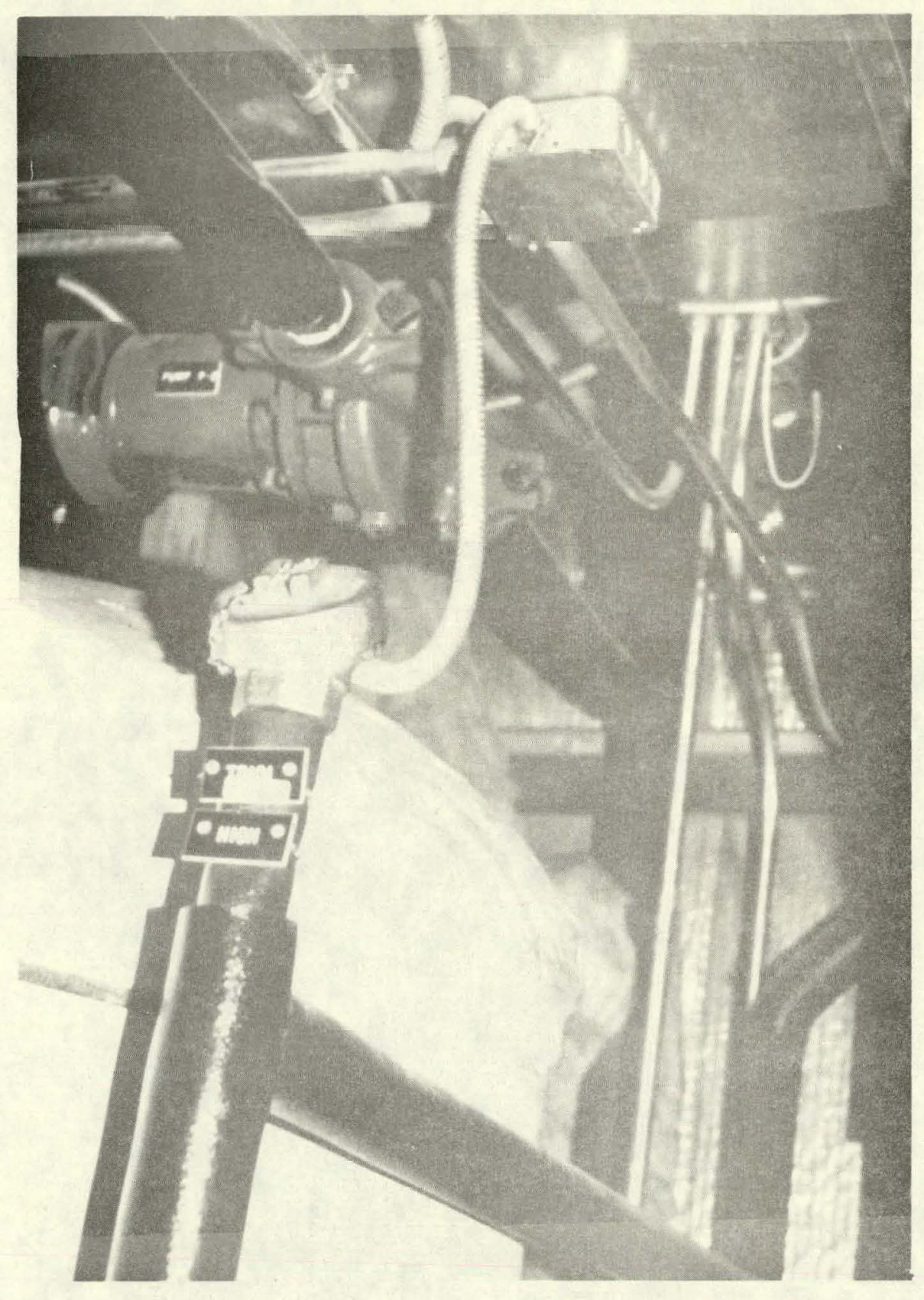

Pump P-2 


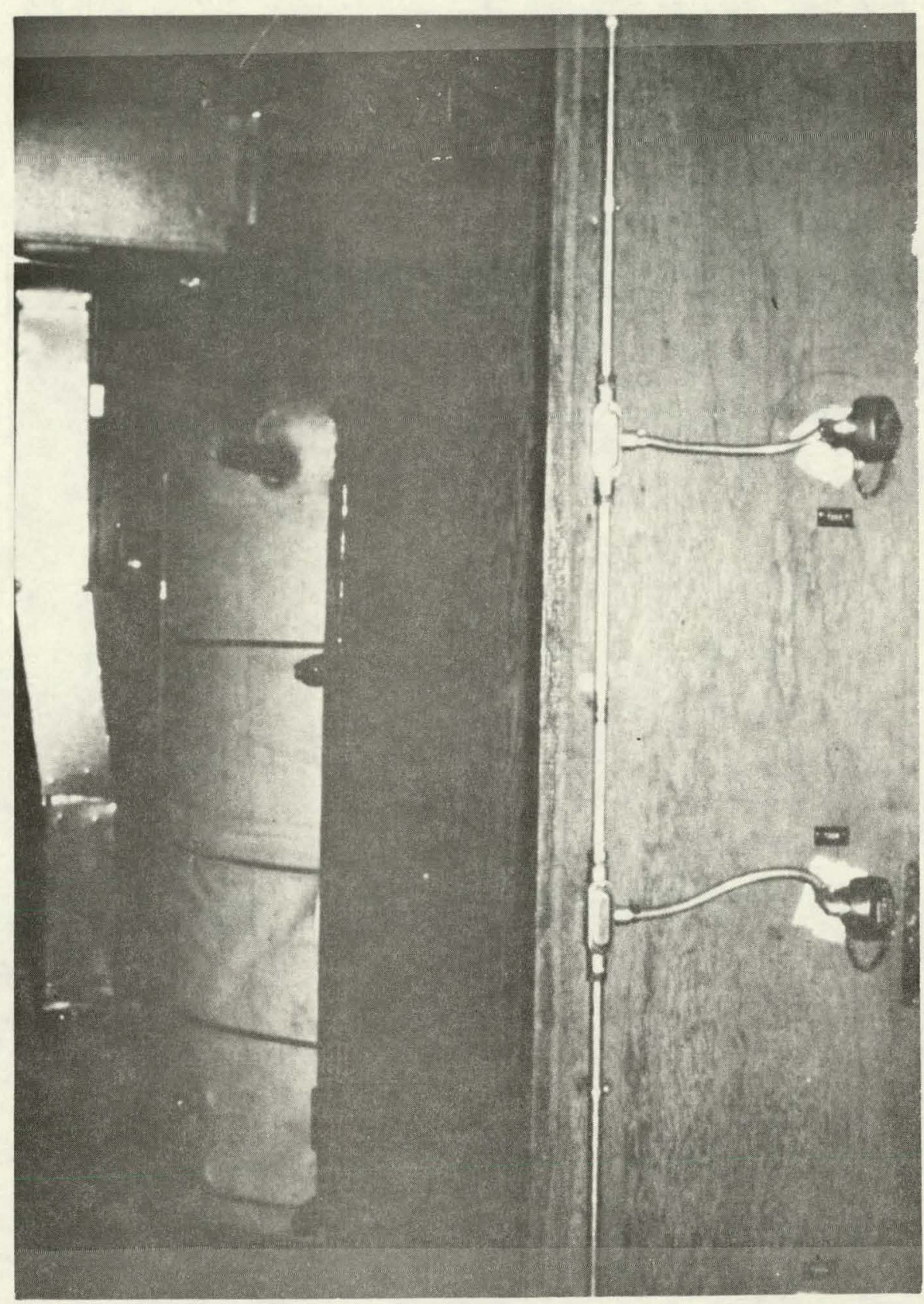

Rock Box 


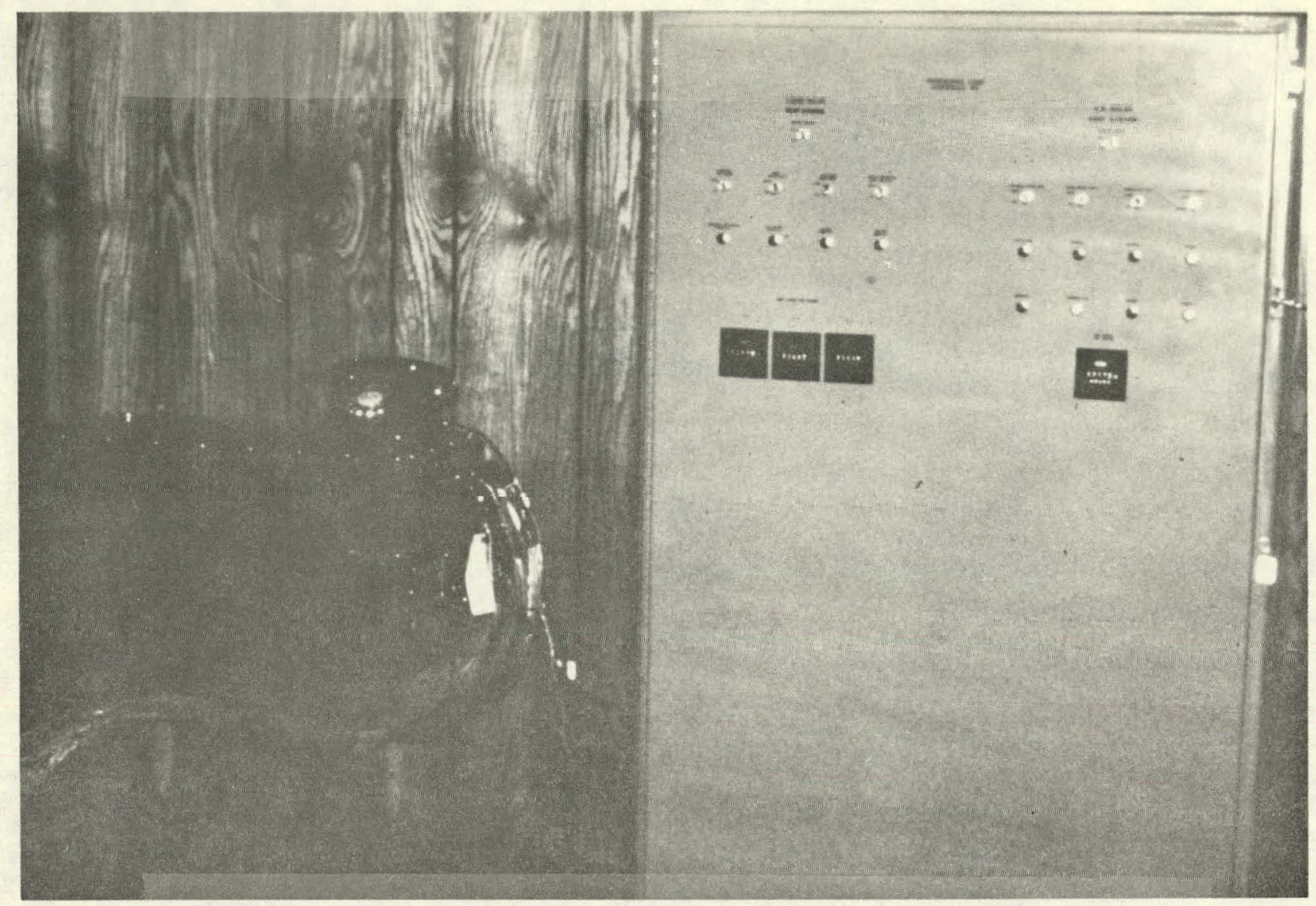

Temperature Control Panel

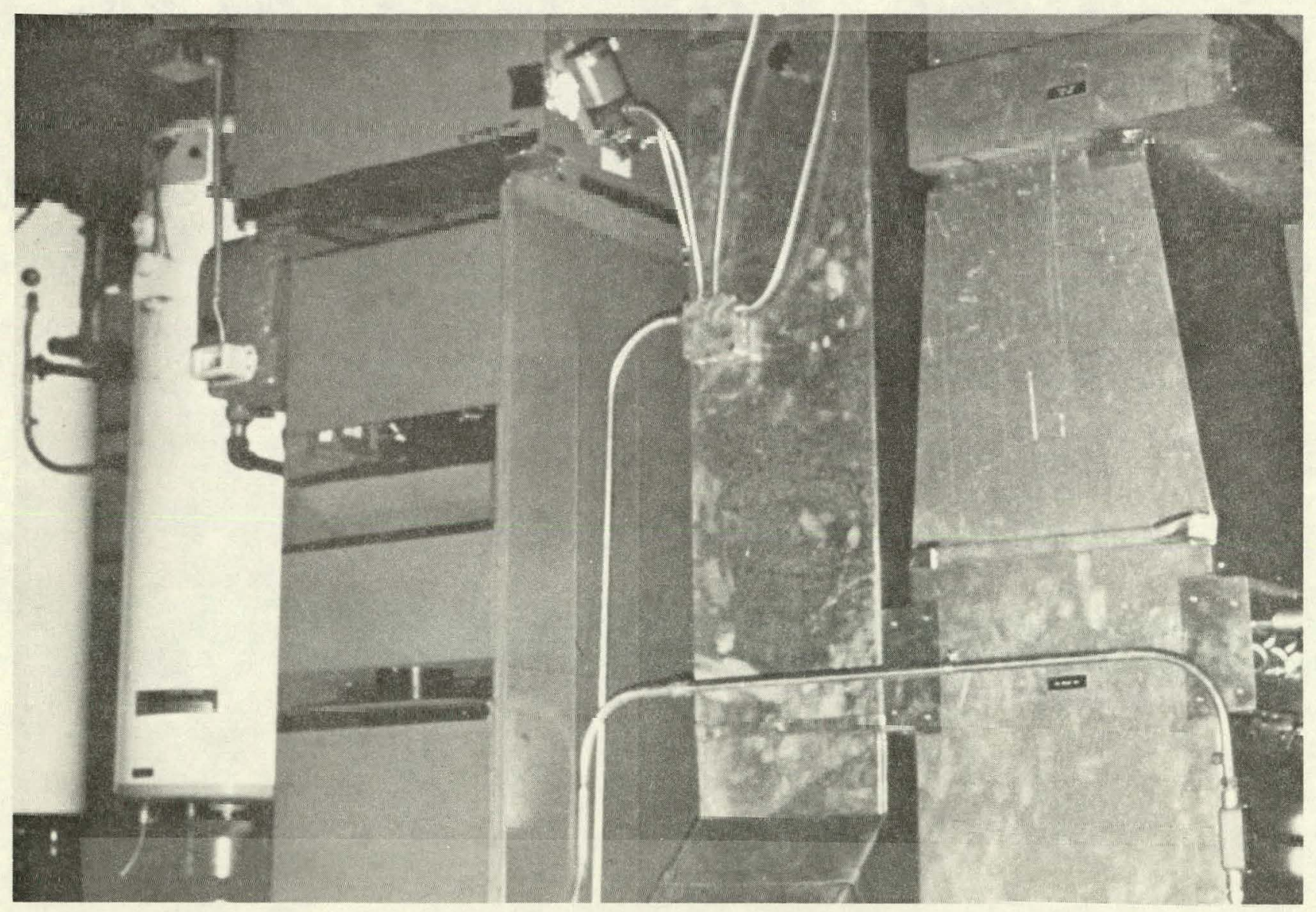

Perimeter Zone Return Air Duct and Counterflow Furnace and Water Heaters 


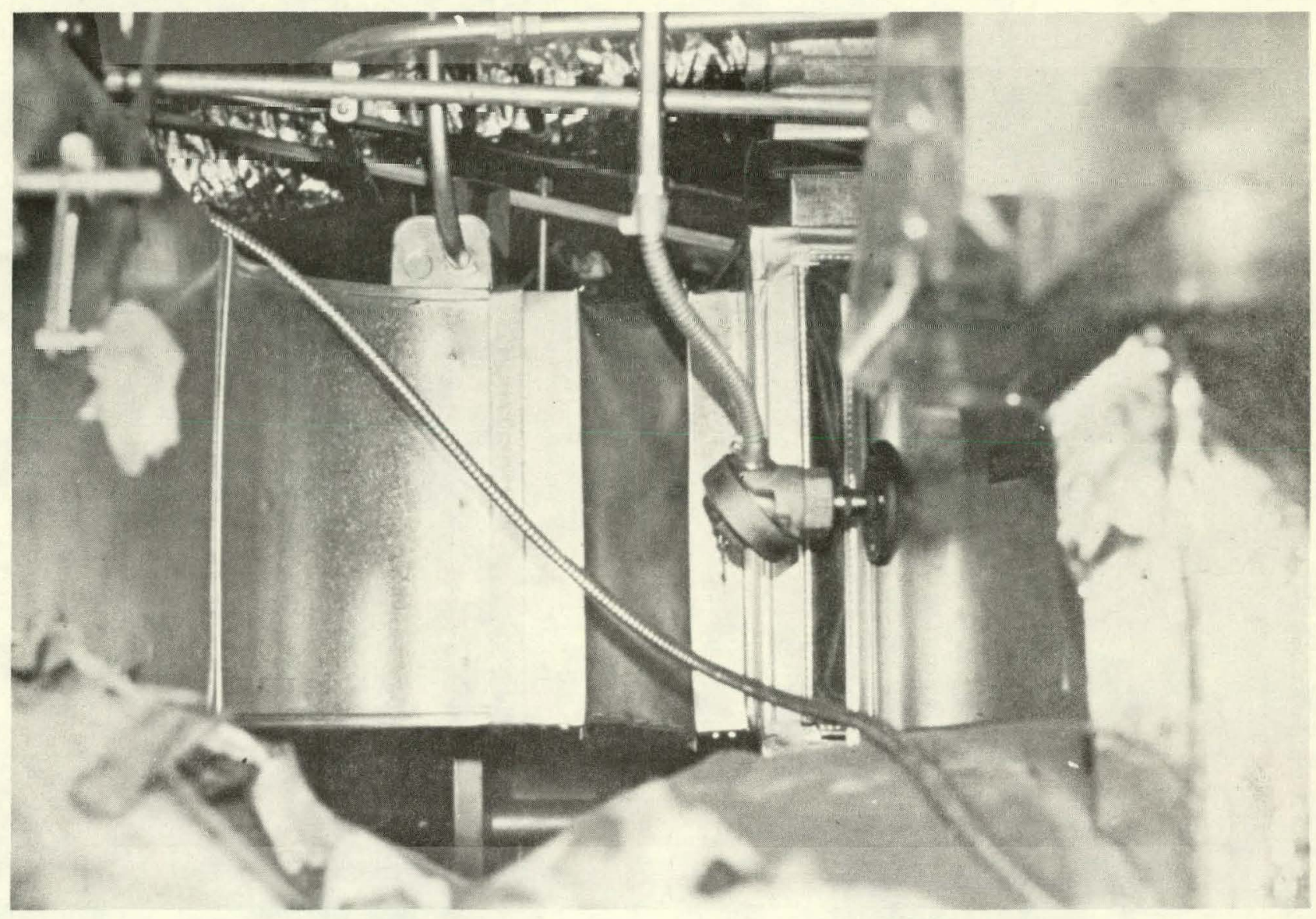

Air Handler Above Ceiling (Very Crowded) 


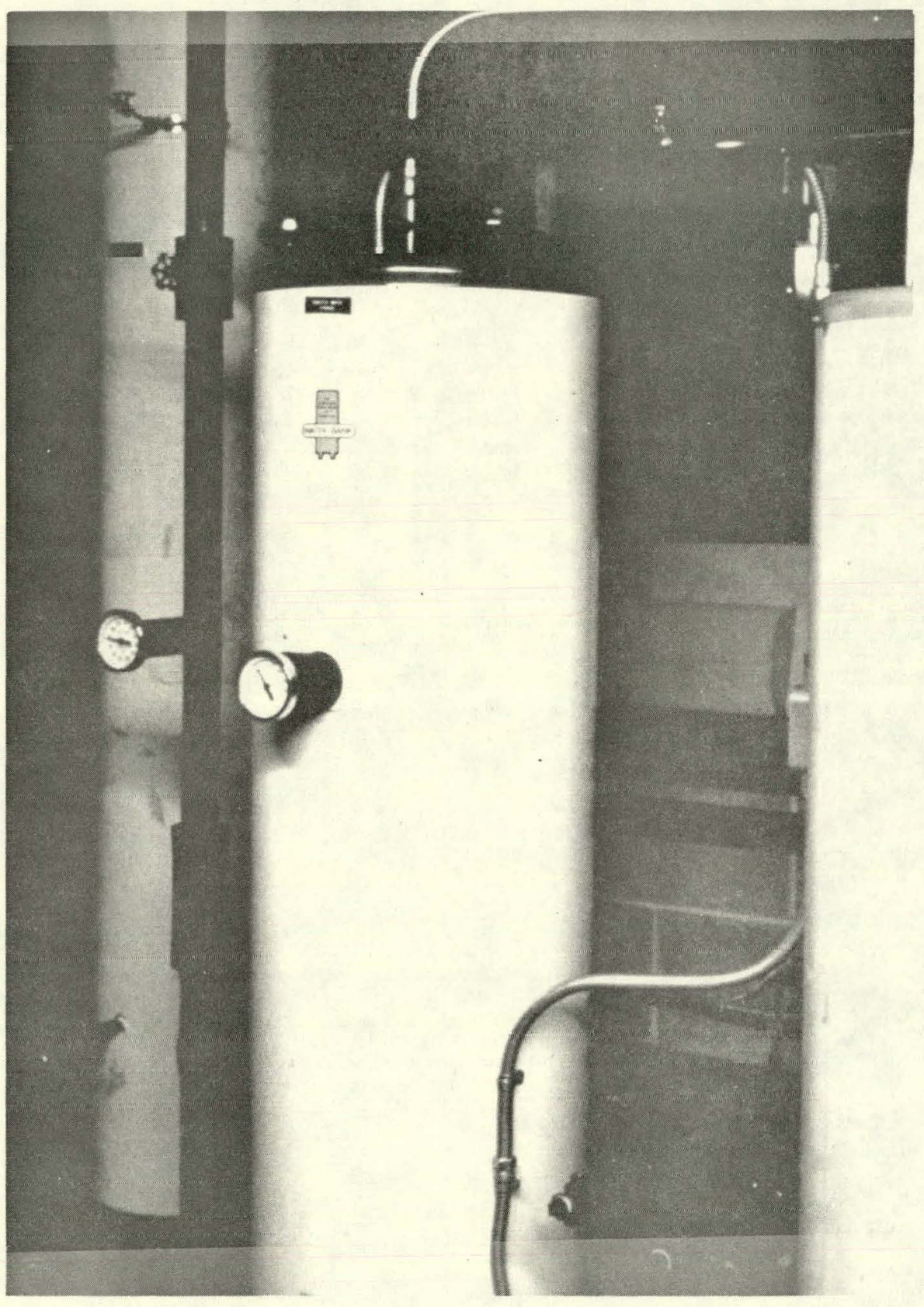

Heat Exchanger on Left - Preheat Domestic Hot Water Heater in Middle - Gas Water Heater on Right 


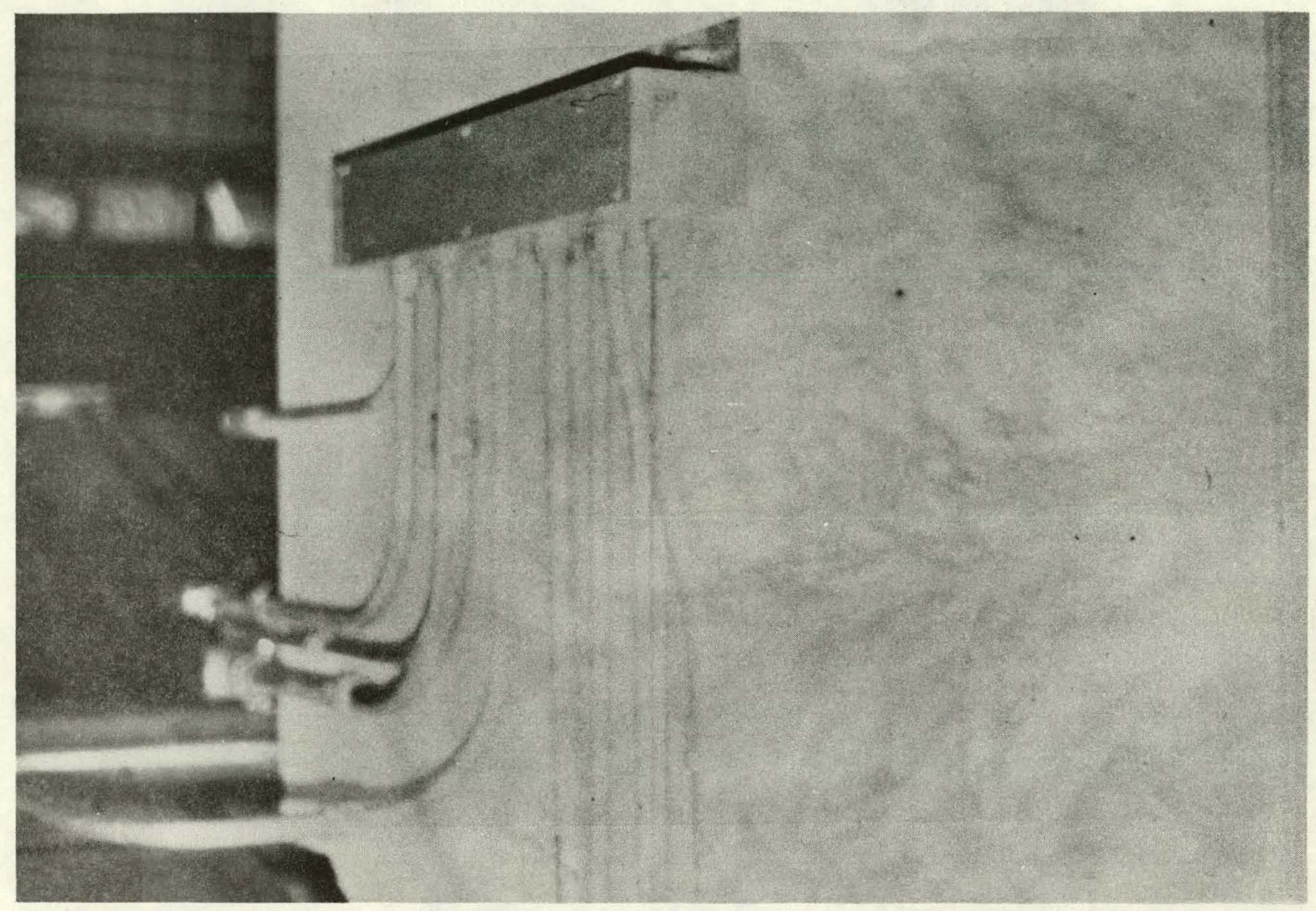

Conduit Rough-In Trough for Monitor 


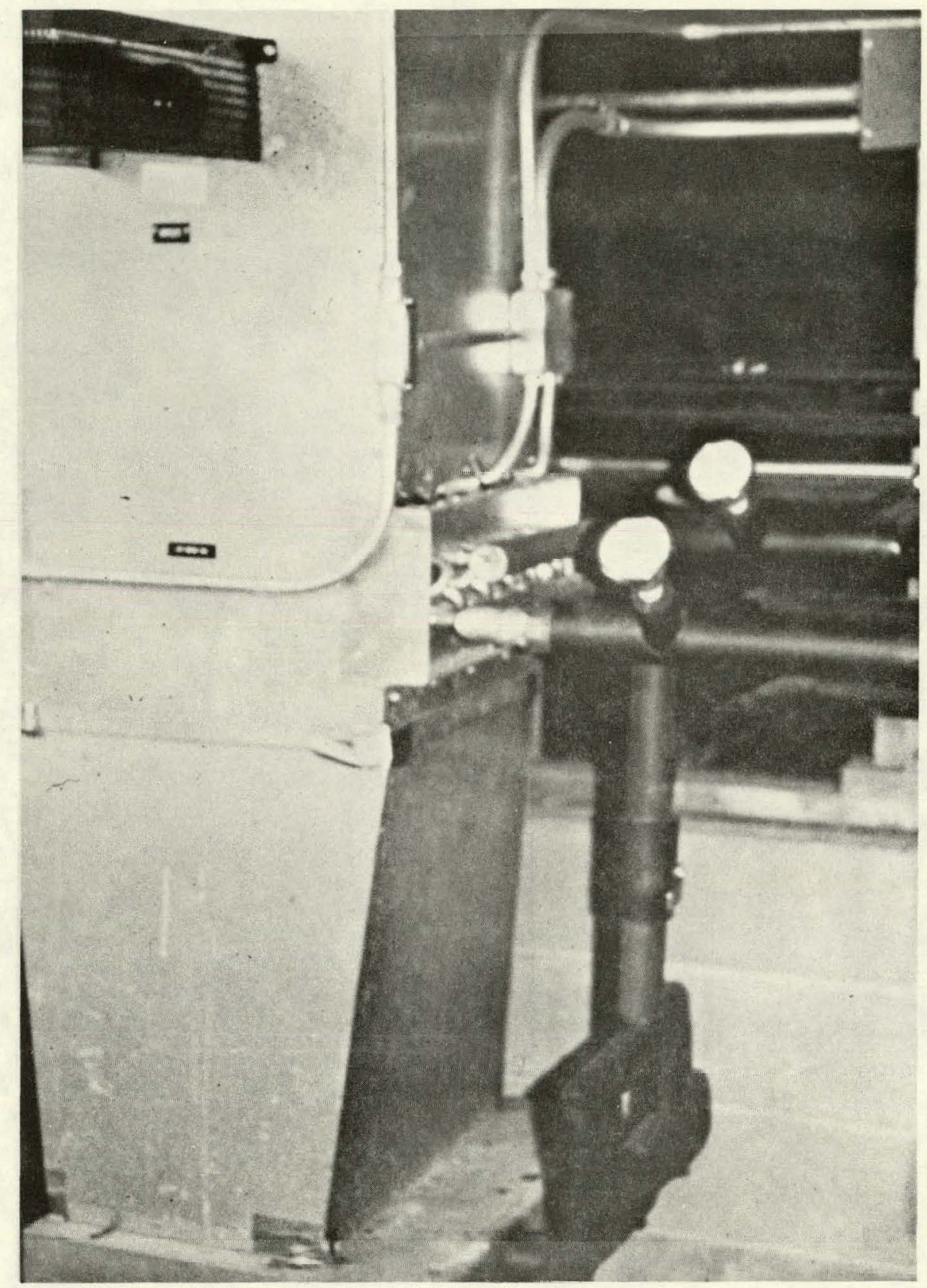

Water Coil Near Center of Picture and Glycol Coil Near Bottom Serving Perimeter Air Handler 


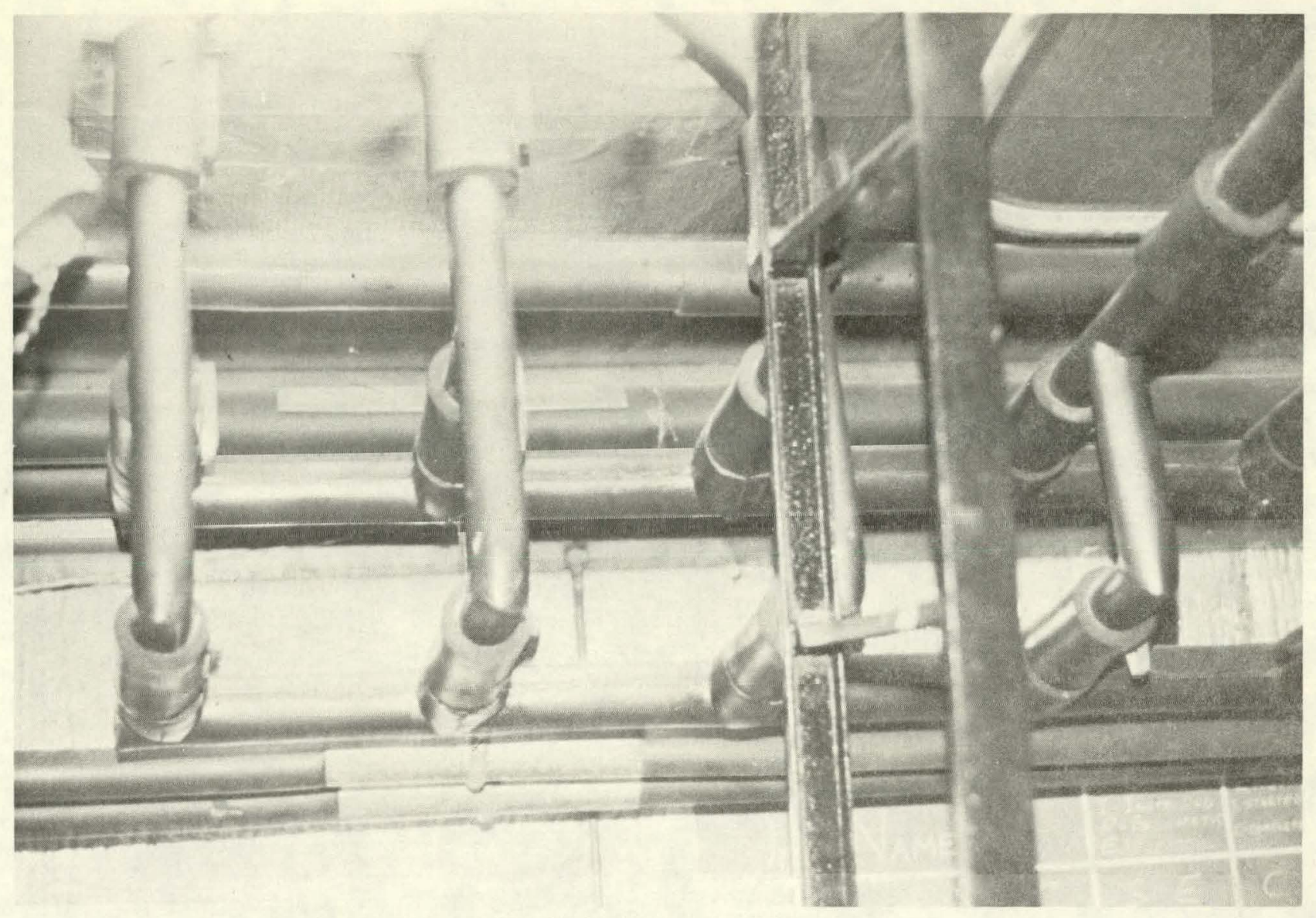

Glycol Piping from Collectors

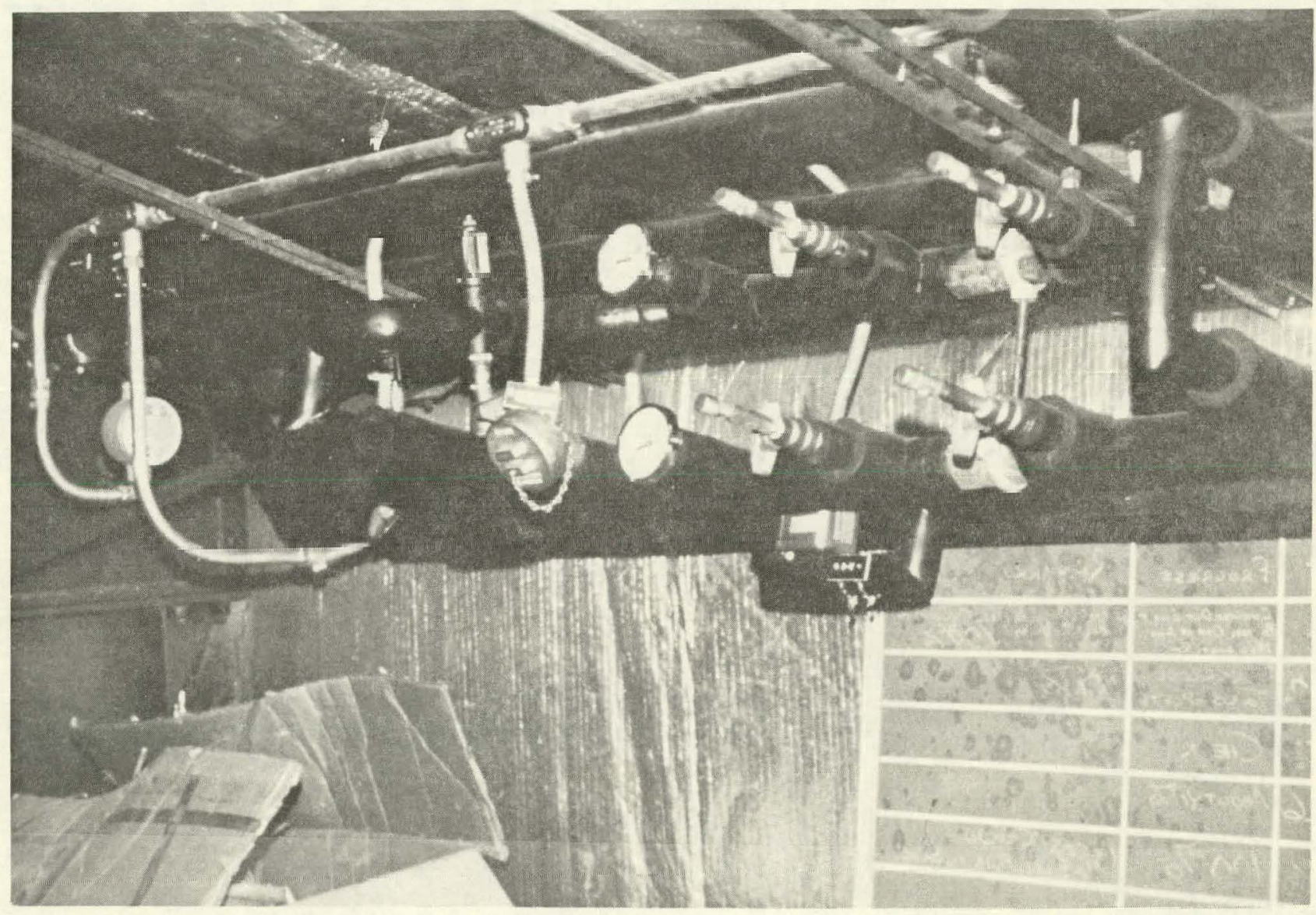

Glycol Piping from Collectors 


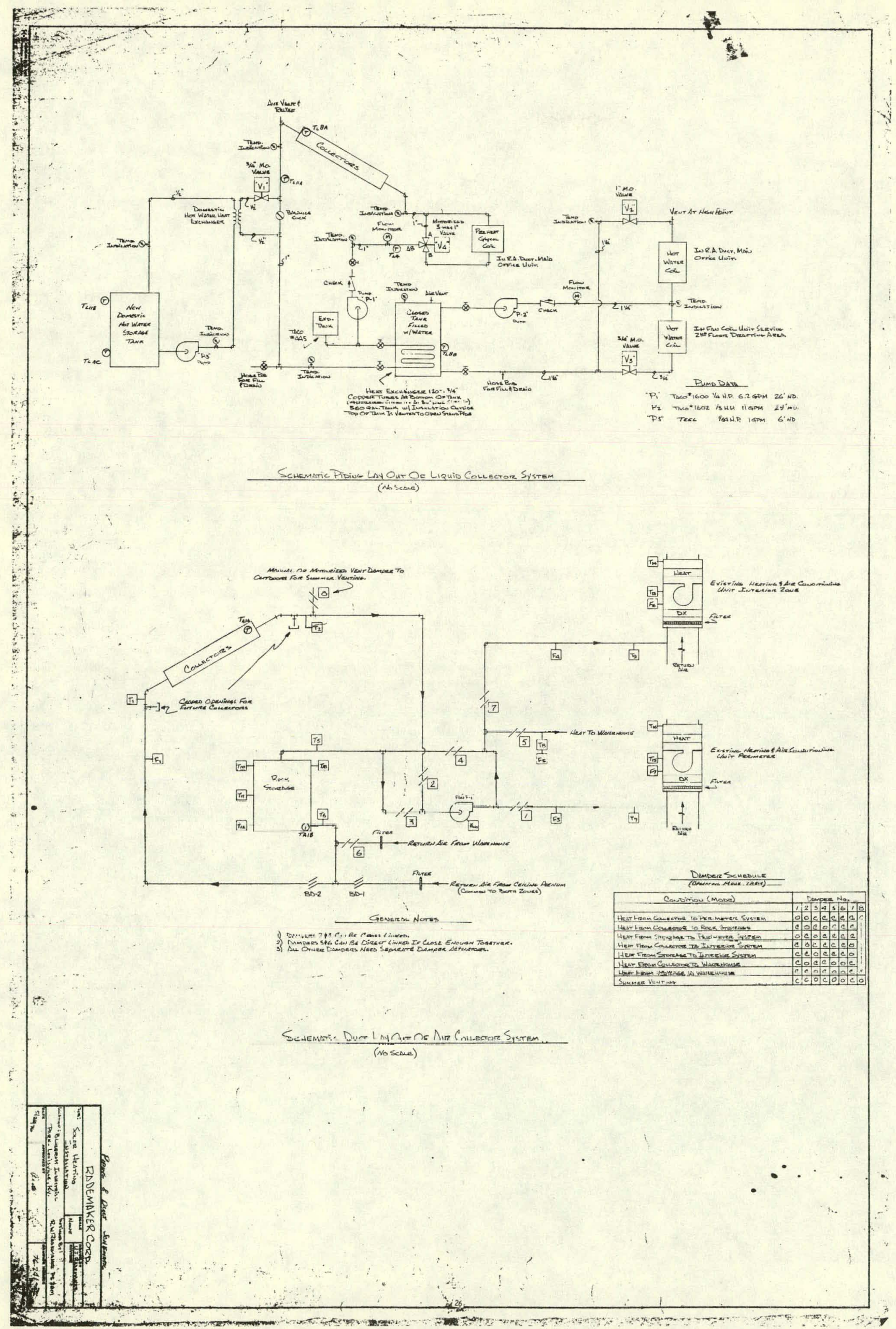




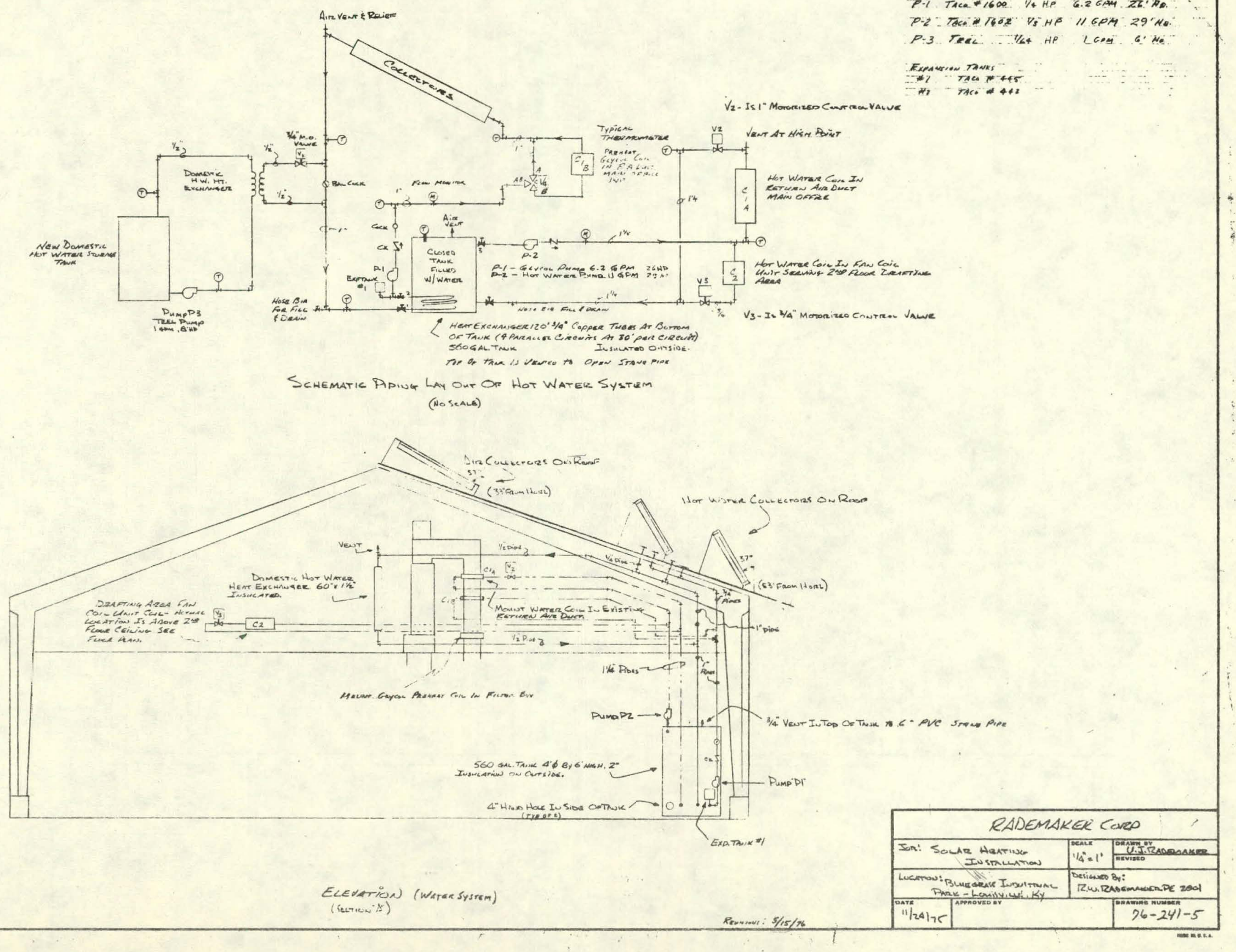



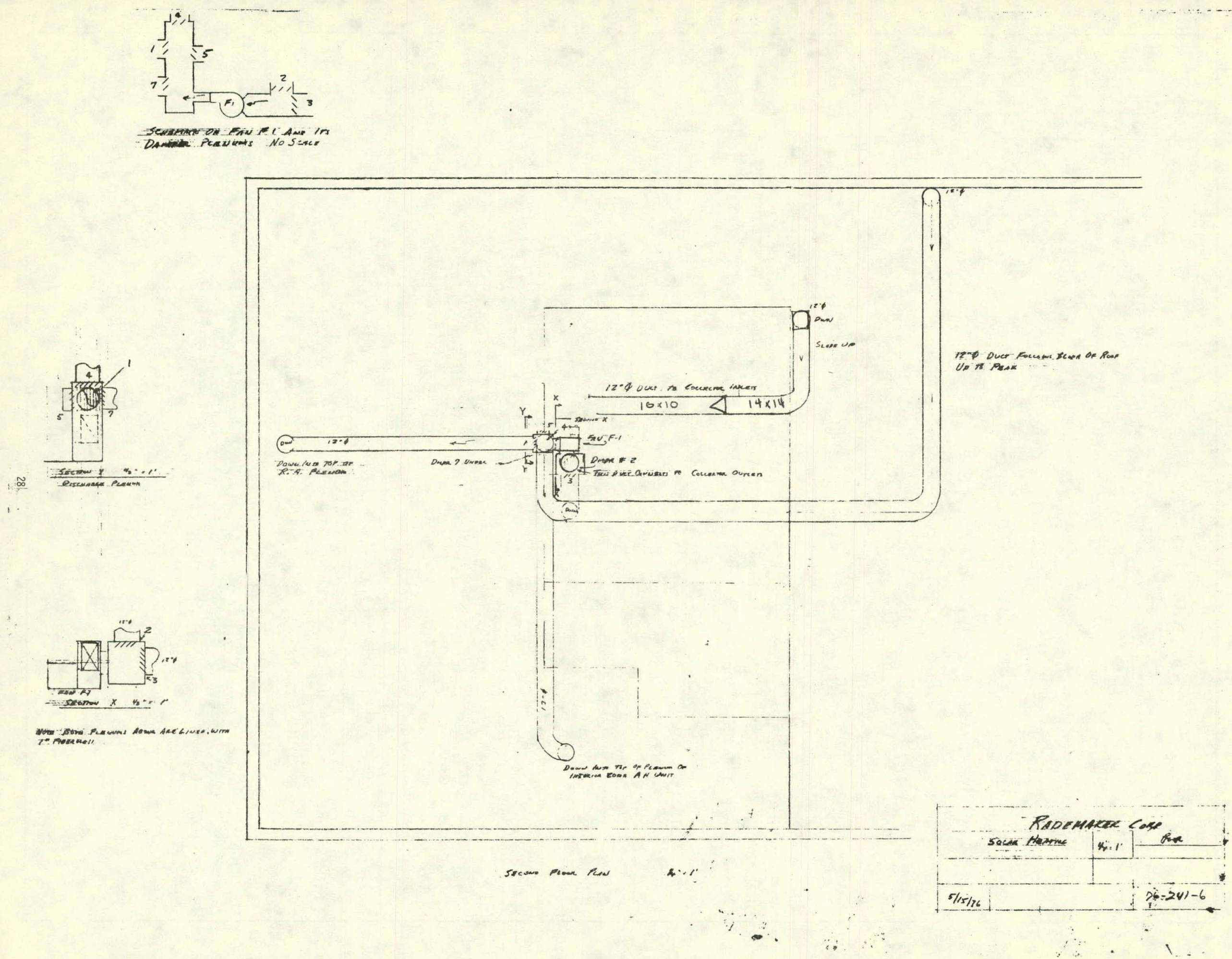


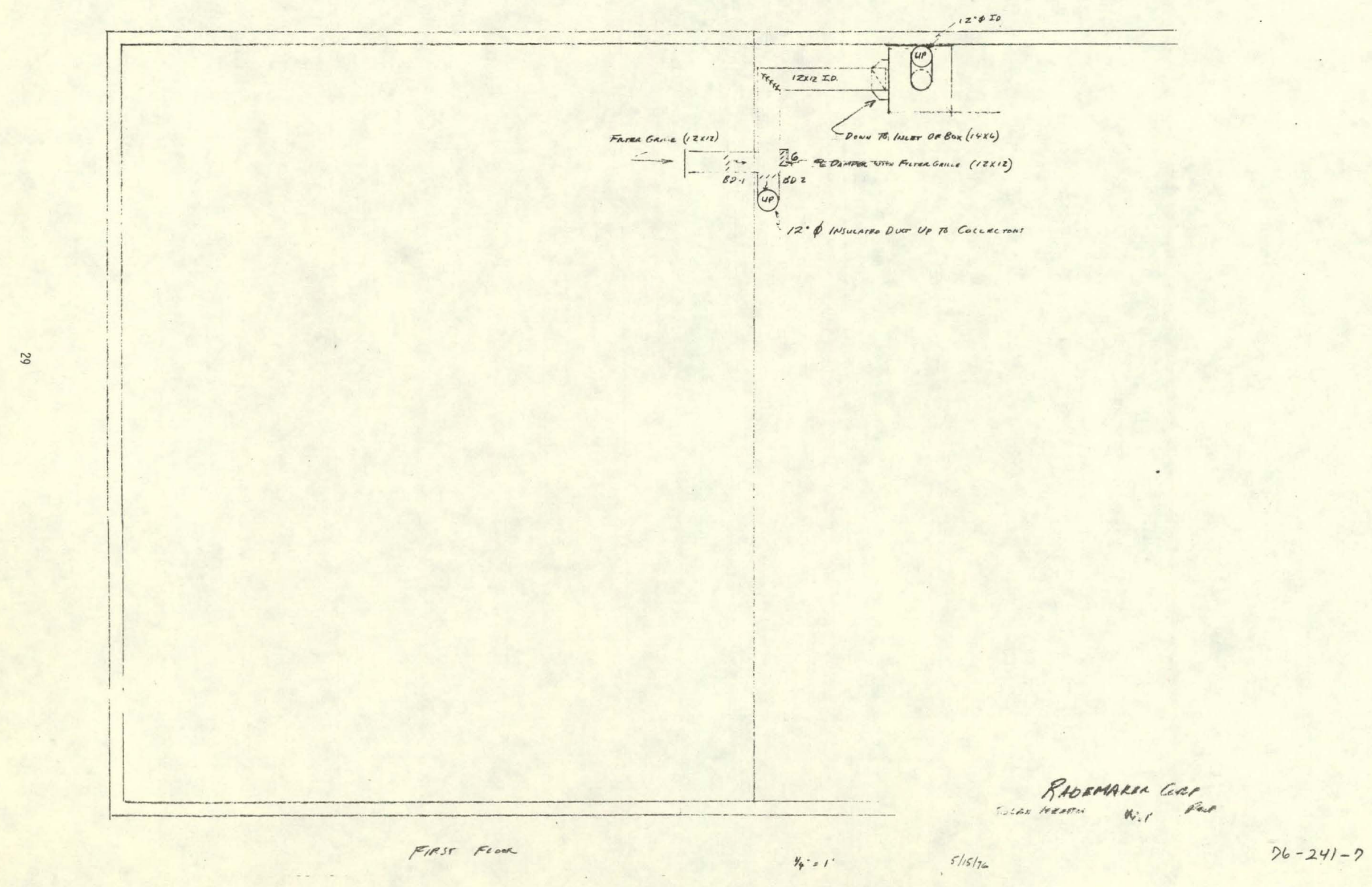


SECTION II

- CONTROLS 


\section{Conzrea Lasis. Narative}

SEGUENCE OF OPEZATION FJR SOLAR HEATINS. SYSTEM, RADEMAKER CORPORATION A. LIQUID CCLLECTCR SYSTEM:

When the master liquid sollector solar heat switch is placed in the "Automatic" pasition (Switch S-1), the differential thermostat T-8 will allow operation of the glycol Pump P-1 through the action of Re ay R-PG. R-PG has a 15 sezond time delay off cycle to prevent fluttering of the glycol pumo if the solid state cirsuit witilin T-8 should flutter mamentarily. Radiation sensing thermostat T-8A under the collector panel near the top of a typical collector surface operates with thermostat $T-8-B$ is the storage tank sensing average water temperature of the :ank to allow operation of the glycol pump when the radiation temperature is greater than the tank temperature. The domestic hot water solar heat switch, S-2, when placed in the "Automatic" position will allow its pump P-3 to operate a: the same time $P-1$ operites threugh Relay $R-0 W$. Different al thermostat $T-11$ has one element T-11-A located on the glycol line leaving the collec:ors, and its auxiliary element T-11-B is on the bottom of the dorestic hot water heater. A high limit safety thermostat T.11-C strapped onto the center of the tank under the insula:ion of the tank allows Pump P-3 to stop if the temperature shculd exceed $180^{\circ}$ on the tank surface. When relay R-OW is energized, Erie valve $k-1$ opens to allow glycol to flow through the heat exchanger serving the domestic hot water circuit.

The roon thermostat serving the exterior zone desicnated as $T-3$ is a two stage heat-one staga cool thernostat. The first stage of heat on this thermostat will energize Relay $R-1$. When Relay $R-1$ is energized and providing Switch $S-3$ is in the "Automatic" pesition (main office heat from liquid solar system switch), hot water valve $v-2$ will open tc preheat coil after the glycol has already passed through the heat exchanger in the tank. (This serves as an economizer to extract more heat from the collector by increasing the efficiency of the collector.) A thermostat $T-4$ sensing the return glycol temperature from the hot water heat excharger will not, however, let this valve open unless the water coming back is above $120^{\circ}$.

The hot water fump $P-2$ which distributes water in the hot water heating system from the storage tank will be energized at any time Relay $R x$ is energized indicating a demand for heat at either zone and provided that the temperature of the water in the top of the storage tank as sensed by thermostat $T-7$ is above $35^{\circ}$ (indicating that heat is available to be distributed to the hot water coils). A switch on the panel $(5-4)$ allows the drafting room air handling unit to operate from the liquid solar heating system. Thermostat T-10 in the drafting rozm will open Erie valve $\mathrm{V}-3$ allowing hot water flow through the fan coil unit's coil whenever heat is demandad in the space. At the same time, the fan will be allowed to operate provided that the hot water pump $P-2$ is running as interlocked througt relay RHA. Relay $R \&$ will energize also which serves as the interlock relay for Pump P-2. Refer to sc lematic wiring diagram for interlock circuit detai1.
It should be pointed out that a second stage of heat demanded by the room thermostat $T-5$ at the perimeter office will allow the gas heat to be energized to bring the space up to temperature.

B. AIR_COLLECTOR SYSTEH:

The master switch for the air collector solar heat system is marked SA-1. Placing this switch in the "Automatic" position allows the differential thermostat $T-1$ to cycle Relay $R-A F$ when the solar radiation input as sensed by thermostat $T A-1 A$ is greater than the temperature at the bottom of the rock storage box as sensed by $T A-1 B$. Switch SA-2 on the control panel when placed in the "Automatic" sosition allows the interior office zone to have heat introduced from the air solar system srovided its room thermostat is calling for heat which in turn would eneraize Relay RA-7. Relay RA-7 will open damper il and will allow starting of fan F-1 which will introduce heat diractly from the solar collector system to the interior zone provided relay R-AF is energized. If not, it will introduce heat from the rock storage stack assuming that thermostat TA-3 indicates a temperature of at least $85^{\circ}$ at the top of the rock storage stack. If heat does not exist from either source, fan $F-1$ will not operate. Switch SA-3 when placed in the "Automatic" position allows heat to enter the main office perimeter zone from the air solar hea: system whenever Thermostat $T-5$ calls for first stage of heat through interlock of a pole $0=$ relay $R-1$. The normally closed contact of relay RA-7 is in series with the circuit to prevent relay RA-1 from energizing if the interior zone thermostat is calling for heat (this gives the interior zone precedence on getting heat from the air collector system). When reTay RA-1 is energized, Damper $\# 1$ opens.

Switch SA-4 when placed in the "Automatic" position allows heat to be introduced to the warehouse from the air solar heat system providing the room thermostat $T A-6$ serving the warehouse zone indicates the demard for heat and further provided that RA-7 and RA-8 relays are not energized indicating a demand for heat in either of the office zones. Ouring the "Automatic" operation, the relay FA-5 upon demand of heat for TA-6 will open dampers " 5 and $: 6$.

The dampers which control heat selection from rock storage or from collectors are controlled from Relay R-AF. If R-AF is energized indicating the collectors have heat available, damper $* 2$ will be opened ard Damper $\neq 3$ will be closed. If R-AF is not energized, damper $" 2$ will be closed and damper is will open to allow heat to come from the rock storage stack. Relay RA-4 will be energized to allow opening of Damper $\# 4$ any time the solar collect ors have heat available and provided that none of the three zones are demanding heat.

A summer vent switch marked SA-5 with indications for "Automatic-Summer" will allow system to work fully automatically as described above when olaced in the "Automatic" position When placed in the "Summer" position, however, relay RA- 8 will be energized allowing heat to vent out the stack to outdoors at the same time Relay RA-5 will be energized allowing damper *5 and 46 to open which provides a natural draft from the warehouse through the collectors, thereby, keeping the collectors reasonaly cool in the summertime.

pilot lights are provided on the panel to indicate which dampers are opened and to indicate when $\operatorname{fan} F-1$ is running, where each of the three pumps is running, and when the fan serving the drafting room is running.

RADEMAKER COZD.

Contrea LoGic Namative

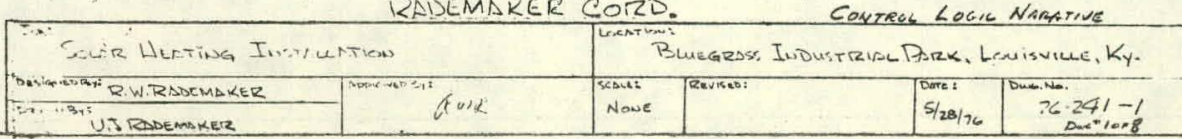




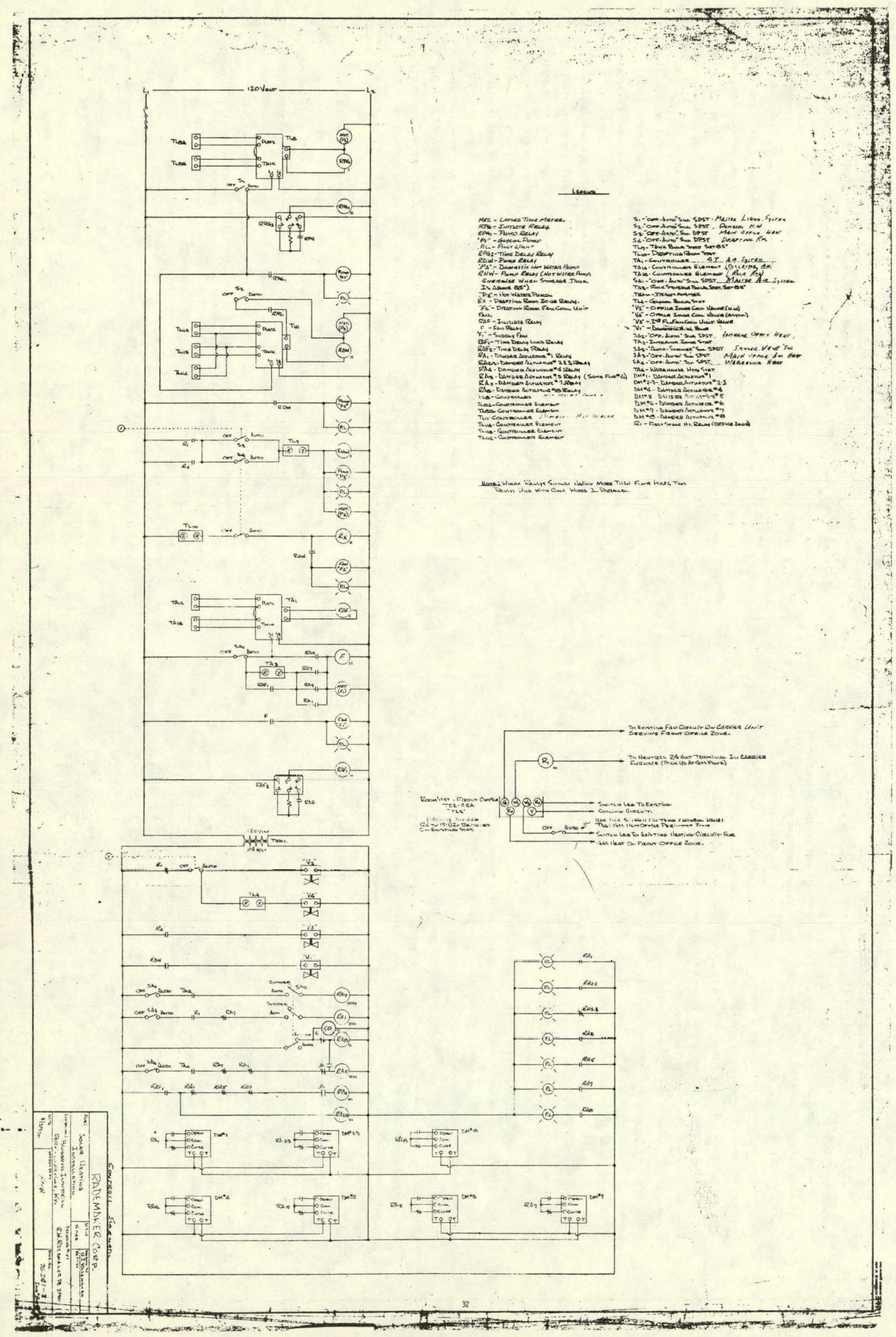




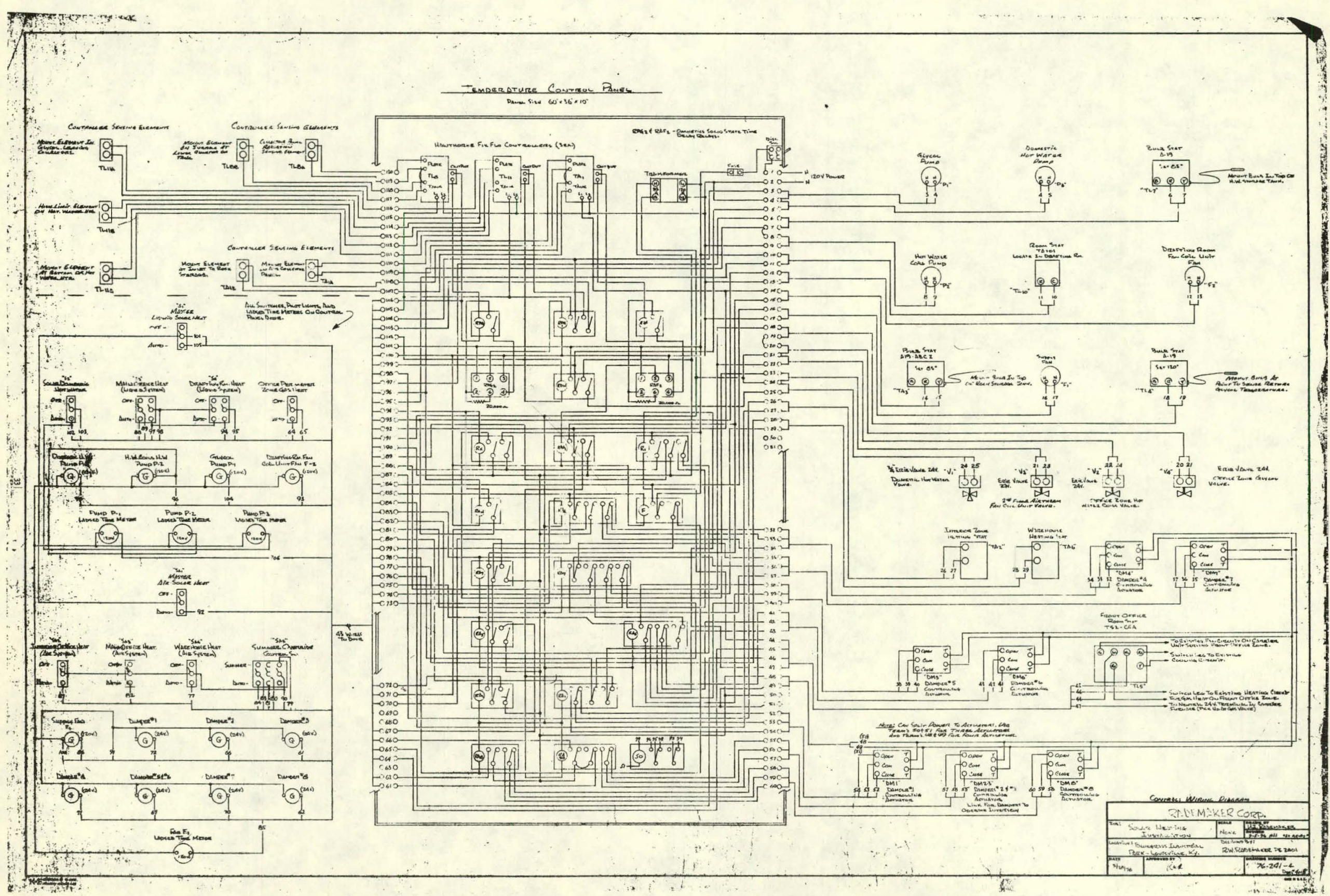


SECTION III

DATA ACQUISITION SYSTEM 
In order to obtain information necessary for evaluation of the performance and operation of the solar heating system throughout the year, 47 sensors were installed within the system. These sensors were furnished by the government and installed at government expense in accordance with the document, "SHC-1006, August 4, 1976; Instrumentation Installation Guidelines for the National Solar Heating and Cooling Demonstration Program."

Table 1 schematic reflects the specific location of each of the sensors.

In Table 2, each sensor is described in terms of generallocation, and the parameter that is being measured. Each sensor is listed by an alpha-numeric code designation. The code designation indicates the following:

\section{Letter Designations}

\begin{tabular}{|c|c|c|c|}
\hline $\mathbf{C}=$ & Specific Heat & $\mathbf{P D}=$ & Pressure Differential \\
\hline $\mathbf{D}=$ & Direction or Position & $Q=$ & Thermal Energy \\
\hline $\mathbf{E} \mathbf{E}=$ & Electrical Energy & $\mathbf{R H}=$ & Relative Humidity \\
\hline $\mathbf{E P}=$ & Electrical Power & $\mathbf{S M}=$ & Special Measurement \\
\hline $\boldsymbol{F}=$ & Fuel Flow Rate & $\mathbf{T}=$ & Temperature \\
\hline $\mathbf{H F}=$ & Heat Flow Meter & $\mathbf{T D}=$ & Differential Temperature \\
\hline $\mathbf{I}=!$ & Incident Solar Flux (Insolation) & $\mathbf{V}=$ & Velocity \\
\hline $\mathbf{N}=$ & $\begin{array}{l}\text { Performance Efficiency or } \\
\text { Effectiveness }\end{array}$ & $\mathbf{W}=$ & $\begin{array}{l}\text { Heat Transport Medium } \\
\text { Flow Rate }\end{array}$ \\
\hline
\end{tabular}


Number Sequence

001 to 099

100 to 199

200 to 299

300 to 399

400 to 499

500 to 599

600 to 699

\section{Data Group}

climatological

collector

thermal storage

domestic hot water

space heating

space cooling

building/load

Each sensor provides data to a Site Data Acquisition Subsystem (SDAS) every 5 minutes around the clock. I'he SDAS digitizes the data and stores it on tape. Once a day the data is sent by telephone to an IBM facility in Huntsville, Alabania, where it is reduced. Monthly reports are prepared, one of which is sent to Rademaker Corporation.

The monitoring system will permit the government to determine the following kinds of inforniation:

- Savings in conventionill cnergy resulting from the use of solar entrgy fö̀ hicating.

o Portion of the tutal heating load supplicd by the solar energy.

- Efficiency of the system in converting solar radiation into useful thermal energy.

- Thermal performance and reliability of major subsystems or components over the demonstration period. 


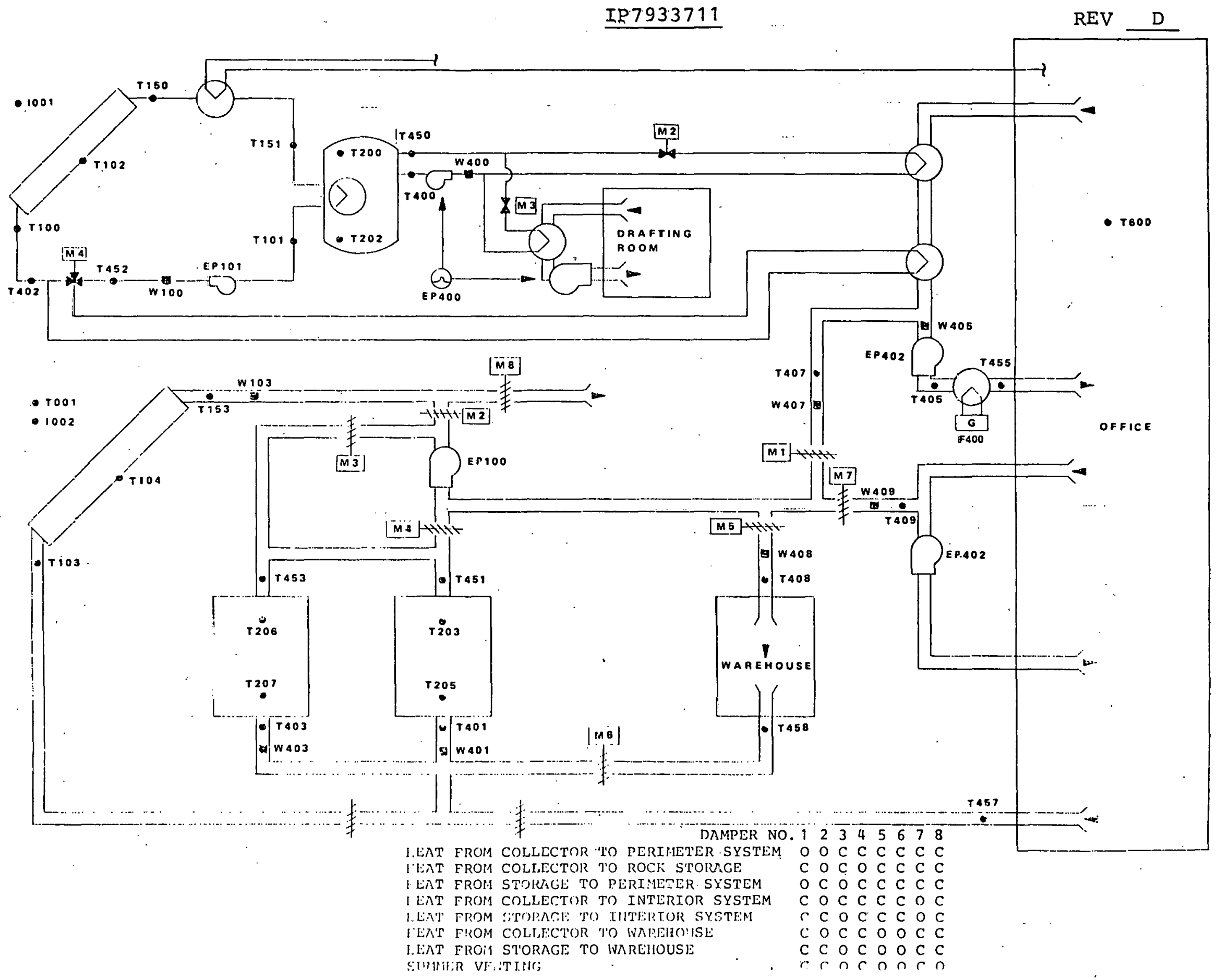


TEMPERATURE INSTRLIMENTATION F.EQUIREMENTS lor RADEMAKEF CORP

7933711

3 APR 1978 Page 1 of 5

\begin{tabular}{|c|c|c|c|c|c|c|c|c|c|c|c|c|c|c|c|}
\hline \multicolumn{9}{|c|}{ Measurement } & \multirow[b]{2}{*}{$\begin{array}{l}\text { Pipe } \\
\text { Type }\end{array}$} & \multirow{2}{*}{$\begin{array}{c}\text { Pipe } \\
\text { Sise } \\
\text { (Inches) }\end{array}$} & \multirow{2}{*}{$\begin{array}{c}\text { Tube } \\
\text { Size } \\
\text { (Inctres) }\end{array}$} & \multirow{2}{*}{$\begin{array}{l}\text { Instal- } \\
\text { ataion } \\
\text { Meinoco }\end{array}$} & \multirow{2}{*}{$\begin{array}{l}\text { Ret } \\
\text { Fig. } \\
\text { No. }\end{array}$} & \multirow{2}{*}{$\begin{array}{l}\text { Thermowell } \\
\text { Parm } \\
\text { No }\end{array}$} & \multirow{2}{*}{$\begin{array}{l}\text { Probe } \\
\text { Pan } \\
\text { No. }\end{array}$} \\
\hline No & Designation & $\mid \frac{1 w}{1-80 x}$ & $\frac{\text { ber }}{S D+S}$ & \begin{tabular}{|l} 
Jussti- \\
tication
\end{tabular} & Nane & $\mathrm{S} N$ & $\frac{\text { Ranc }}{\text { Min. }}$ & $\frac{\left({ }^{\circ} \mathrm{F}\right)}{\text { Max. }}$ & & & & & & & \\
\hline 1 & ToQ: & 30 & & $\$ 1113$ & Ambient air dr: bulb terip & & & & & VA & & & & IS4 & $\$ 53 P 85236$ \\
\hline 2 & $\mathrm{~T} 100$ & 2 & & 0100 & Collector array inlet temp liguid & & & & CU & 1 & & & & F203U42 & S57P72Z36 \\
\hline 3 & $\pi 150$ & 32 & & Q100 & Collector arra: outlet temp liquid & & & & Cu & $1 / 1$ & & & & F203042 & S53P72236 \\
\hline 4 & $\mathrm{TlC2}$ & 34 & & 11116 & Collector absorber surface temp liquid & & & & & & & & & & S34A \\
\hline 5 & $T 1013$ & 36 & & $0100^{\circ}$ & Collector array inlet temp air & & & & Air Duct & & & & & Fl32 & $\$ 57 P 85 Z 36$ \\
\hline 6 & $T I E 3$ & 6 & & $Q 100$ & Collector arra: outlet temp air & & & & Air Duct & & & & & F132 & S53P85Z36 \\
\hline 7 & $\mathrm{TlO4}$ & 38 & & 11116 & Collector absorber surface temp air & & & & & & & & & & S34A \\
\hline 8 & 1101 & 4 & & $0 \leq 00$ & Storage tank outlet temr-callector loon & & & & $\mathrm{CU}$ & $1 / 1$ & & & & $\mathrm{~F} 203 \mathrm{U42}$ & $553 \mathrm{P} 72736$ \\
\hline 9 & $T 450$ & 12 & & 0201 & Storate tank outlet-to-loac temp & & & & CU & $1-1 / 4$ & & & & $F 203042$ & $\$ 53 P 72 Z 36$ \\
\hline 10 & $\mathrm{~T} 4 \mathrm{CO}$ & 7 & & Q201 & Storage tank temp load & & & & CU & $1-1 / 4$ & & & & F203U42. & $557 P 72 Z 36$ \\
\hline 11 & $T 200$ & 40 & & Q202 & Storage taak temp - top licuid & & & & & & & & & F203U154 & $553 P 180230$ \\
\hline 12 & $\mathrm{~T} 202$ & 42 & & 0202 & Storage ta $7 k$ temp - bottom liquid & & & & & & & & & $F 2030154$ & S53P180Z36 \\
\hline 13 & T203 & 43 & & Q202 & Fock storage temp - top & & & & & & & & & F203U154 & S53P 780236 \\
\hline 14 & $\mathrm{~T} 205$ & 45 & & 0202 & Fock storaje temp - bottom & & & & & & & . & & F203U154 & S53P180Z36 \\
\hline 15 & T451 & 14 & & $\begin{array}{l}0200 / \\
0201\end{array}$ & $\begin{array}{l}\text { Eock storaje, inlet-to-outlet } \\
\text { cifferential temp }\end{array}$ & & & & Air Duct & & & & & El 132 & $S 53 P 85736$ \\
\hline 16 & $T 452$ & 16 & & 0402 & Glycol coil, irilet temp & & & & CU & 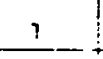 & & & & $\mathrm{E} 203 \mathrm{U} 42$ & $553 P 72736$ \\
\hline 17 & $T 455$ & 20 & & Q401 & Furnace outlet temp air & & & & Air Duct & & & & & Fl32 & $553 P 85736$ \\
\hline 18 & 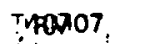 & 24 & & Q402 & Ferimeter air temp & & & & Air Duct & & & & & Fl32 & S53P85Z36 \\
\hline
\end{tabular}

TABLE 2 
TEMPERATURE INSTRUMENTATION REOUIREMENTS for ___RADEMAKER CORP 7933711

\begin{tabular}{|c|c|c|c|c|c|c|c|c|c|c|c|c|c|c|c|}
\hline \multicolumn{9}{|c|}{ Measurement } & \multirow[b]{2}{*}{$\begin{array}{c}\text { Pipe } \\
\text { Type }\end{array}$} & \multirow{2}{*}{$\begin{array}{c}\text { Pipe } \\
\text { size } \\
\text { (Inches) }\end{array}$} & \multirow{2}{*}{$\begin{array}{c}\text { Tube } \\
\text { Sue } \\
\text { (Inches) }\end{array}$} & \multirow[b]{2}{*}{$\begin{array}{l}\text { Instal- } \\
\text { lation } \\
\text { Metinod }\end{array}$} & \multirow[b]{2}{*}{$\begin{array}{l}\text { Ret. } \\
\text { Fig. } \\
\text { No. } \\
\end{array}$} & \multirow{2}{*}{$\begin{array}{l}\text { Therriowell } \\
\text { Patt } \\
\text { No. }\end{array}$} & \multirow[b]{2}{*}{$\begin{array}{l}\text { Probe } \\
\text { Pann } \\
\text { No. }\end{array}$} \\
\hline No. & Lesignation & $\frac{N_{u}}{J-B O x}$ & $\frac{1}{S D A S}$ & $\begin{array}{l}\text { Justi- } \\
\text { tication } \\
\end{array}$ & Name & SN & $\frac{\operatorname{Ran}}{\text { Min. }}$ & $\frac{\left({ }^{\circ} F\right)}{\operatorname{Max} .}$ & & & & & & & \\
\hline 19 & $T 403$ & 26 & & Q402 & Air to warehzuse temp & & & & Air Duct & & & & & $\mathrm{F} 132$ & $\$ 53 P 85 z 36$ \\
\hline 20 & $T 409$ & 28 & & Q402 & Air to interior temp & & & & Air Duct & & & & & $\mathrm{F} 132$ & $553 P 85236$ \\
\hline 21 &.$T 600$ & 11 & - & N406 & Building indoor, avg. temp, downstairs & & & & & & & & & $\mathrm{F} 132$ & S53P85Z36 \\
\hline 22 & $\mathrm{~T} 453$ & 18 & & \begin{tabular}{|l|l}
$Q 0200 /$ \\
$Q 201$
\end{tabular} & $\begin{array}{l}\text { Under-floor rock storage, inlet-to- } \\
\text { outlet differential temp }\end{array}$ & & & & Air Duct & & & & & FI32 & $553 P 85236$ \\
\hline 23 & T206 & 46 & & Q202 & $\begin{array}{l}\text { Under-floor rock storage, internal } \\
\text { Temp near in!et }\end{array}$ & & & & & & & & & F203U154 & $553 P 180236$ \\
\hline 24 & $T 207$ & 47 & & Q202 & $\begin{array}{l}\text { Under-floor rock storage, internal } \\
\text { temp near ou:let }\end{array}$ & & & & & & : & & & F203U754 & S53P180Z36 \\
\hline 25 & T151 & 8 & & & Storage tank $H X$ glycol inlet temp & & & & & & & & & & S53P7.2 \\
\hline 26 & $\mathrm{~T} 4001$ & 9 & & & Main storage temp outlet air & & & & & & & & & & $553 P 85$ \\
\hline 27 & $\mathrm{~T} 403$ & 10 & & & Under-floor storage outlet air & & & & . & & & & & & S53P85 \\
\hline 28 & $T 458$ & 22 & & & Air temp from warehouse & & & & & & & & & & S53P85 \\
\hline 29 & $T 457$ & 31 & & & Air temp fromi office & & & & & & & & & & $\$ 53 P 85$ \\
\hline 30 & $T 402$ & 48 & & & Preheater glycol outlet temp & & & & & & & & & & \$53P72 \\
\hline 31 & $\mathrm{~T} 405$ & 44 & & & Auxiliary furnace air inlet temp & & & & & & & & & & \\
\hline & & & & & " & & & & & & & & & & \\
\hline & & & & & & & & & & & & & & & \\
\hline & & & & & & & & & & & & & & & \\
\hline & & & & & . & & & & & & & & & & \\
\hline & & & & & & & & & & & & & & & \\
\hline
\end{tabular}


FLOW RATE INSTRUMENTATION REQUIREMENTS for

RADEMAKER CORP

7933711

3 APR 1978

Page 3 of 5

\begin{tabular}{|c|c|c|c|c|c|c|c|c|c|c|c|c|c|c|c|}
\hline \multicolumn{10}{|c|}{ Measurement } & \multicolumn{2}{|c|}{ Liquid Flow } & \multirow{2}{*}{\multicolumn{3}{|c|}{$\frac{\text { Air Flow }}{\text { Duct Dimensions (In.) }}$}} & \multirow{3}{*}{$\begin{array}{l}\text { Model } \\
\text { No. }\end{array}$} \\
\hline \multirow{2}{*}{ No } & \multirow{2}{*}{ Designation } & \multicolumn{2}{|c|}{ Nutnber } & \multirow{2}{*}{$\begin{array}{l}\text { Justi- } \\
\text { lication }\end{array}$} & \multirow{2}{*}{ Name } & \multirow{2}{*}{$\mathrm{S} / \mathrm{N}$} & \multicolumn{3}{|c|}{ Range (GPM/CFM) } & \multirow{2}{*}{$\begin{array}{l}\text { Pipe } \\
\text { Type }\end{array}$} & \multirow{2}{*}{$\begin{array}{l}\text { Fipe } \\
\text { Size }\end{array}$} & & & & \\
\hline & & $\mathrm{J}$ - Bo. & SOAS & & & & Min. & Design & Max. & & & L & $w$ & $T$ & \\
\hline 32 & W100 & 19 & & Q100 & Collector array flow rate - total & & & & & & 1 & & & & MKV -1-J07 \\
\hline 33 & 4103 & 13 & & 2100 & Collector array flow rate - total & & & $363 \mathrm{FPM}$ & & $\begin{array}{l}\text { Air } \\
\text { Duct }\end{array}$ & & & & & $430-2$ \\
\hline 34 & W400 & 33 & & Q201 & $\begin{array}{l}\text { Space heating system - storage outlet } \\
\text { to load flow rate }\end{array}$ & & & & & & $1-7 / 4$ & & & & $1 M K V-1-1 / 4-J 07$ \\
\hline 35 & 1405 & 15 & & Q401 & Ferimeter air cond/htg unit, air flow rate & & & $675 \mathrm{FPM}$ & & $\begin{array}{l}\text { Air } \\
\text { Duct }\end{array}$ & & 19 & 18 & & $430-2$ \\
\hline 36 & 6401 & 17 & & Q40.1 & storage flow rate, air & & & $575 \mathrm{FPM}$ & & $\begin{array}{l}\text { Air } \\
\text { Duct }\end{array}$ & & 25 & 16 & & $430-2$ \\
\hline 37 & W407 & 23 & & Q402 & $\begin{array}{l}\text { Ferimeter air cond/ritg unit, flow rate } \\
\text { of solar heat ad air }\end{array}$ & & & 400FPM & & $\begin{array}{l}\text { Air } \\
\text { Duct }\end{array}$ & r & & & & $430-2$ \\
\hline 38 & W408 & 27 & & Q40c & $\begin{array}{l}\text { Solar heating loop to werefouse zone } \\
\text {-low rate of solar heated cir }\end{array}$ & & & $400 \mathrm{FPM}$ & & \begin{tabular}{|l|} 
Air \\
Duct \\
\end{tabular} & & & & & $430-2$ \\
\hline 39 & 11409 & 29 & & Q40厃̈ & $\begin{array}{l}\text {-nterior zone air cond/hitg urit, flow } \\
\text { rate of solar hea sed air }\end{array}$ & & & 400FFM & & $\begin{array}{l}\text { Air } \\
\text { Duct }\end{array}$ & & & & & $430-2$ \\
\hline 40 & $\mathrm{~F} 400$ & $\approx 5$ & & Q410 & $\begin{array}{l}\text { Perimeter air cond/htg unit, natural } \\
\text { gas auxiliary inlet fłow, sotailized } \\
\end{array}$ & & & 2.1CFM & & & $3 / 4$ & & & & $\begin{array}{l}\text { American Meter } \\
\text { AL-175-M }\end{array}$ \\
\hline 41 & $W 403$ & $\Xi 7$ & & Q406 & Jnder-flecr rock storage, air slow & & & 400CFM & & $\begin{array}{l}\text { Air } \\
\text { Duct }\end{array}$ & & & & & $430-2$ \\
\hline & & & & 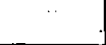 & $\cdots$ & & & & & & & & & $\cdots \cdot \cdot \cdot$ & \\
\hline & & & & & & & & . & & & & & & & \\
\hline & & $\cdots$ & & & & & . & & & & & & & & \\
\hline & & . & & & 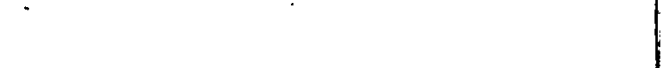 & & & & & & & & & & \\
\hline & & & & & & & & & & & & & & & \\
\hline & & & & & & & & & & & & & . & & \\
\hline & & & & & & & & & & & & & & & \\
\hline & & & & & & & & & & & & & & & \\
\hline
\end{tabular}

TABLE 2 


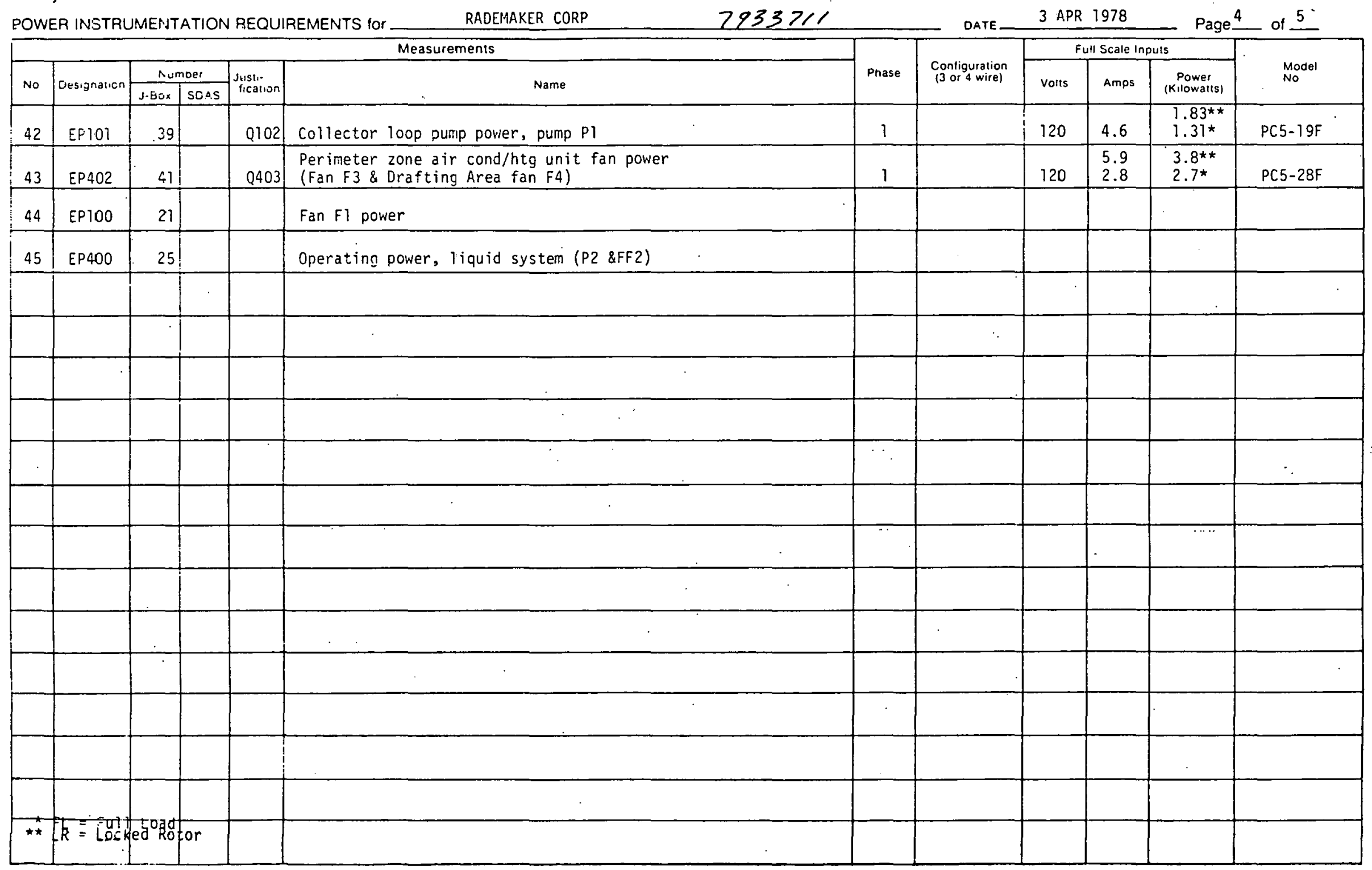

TABLE 2 


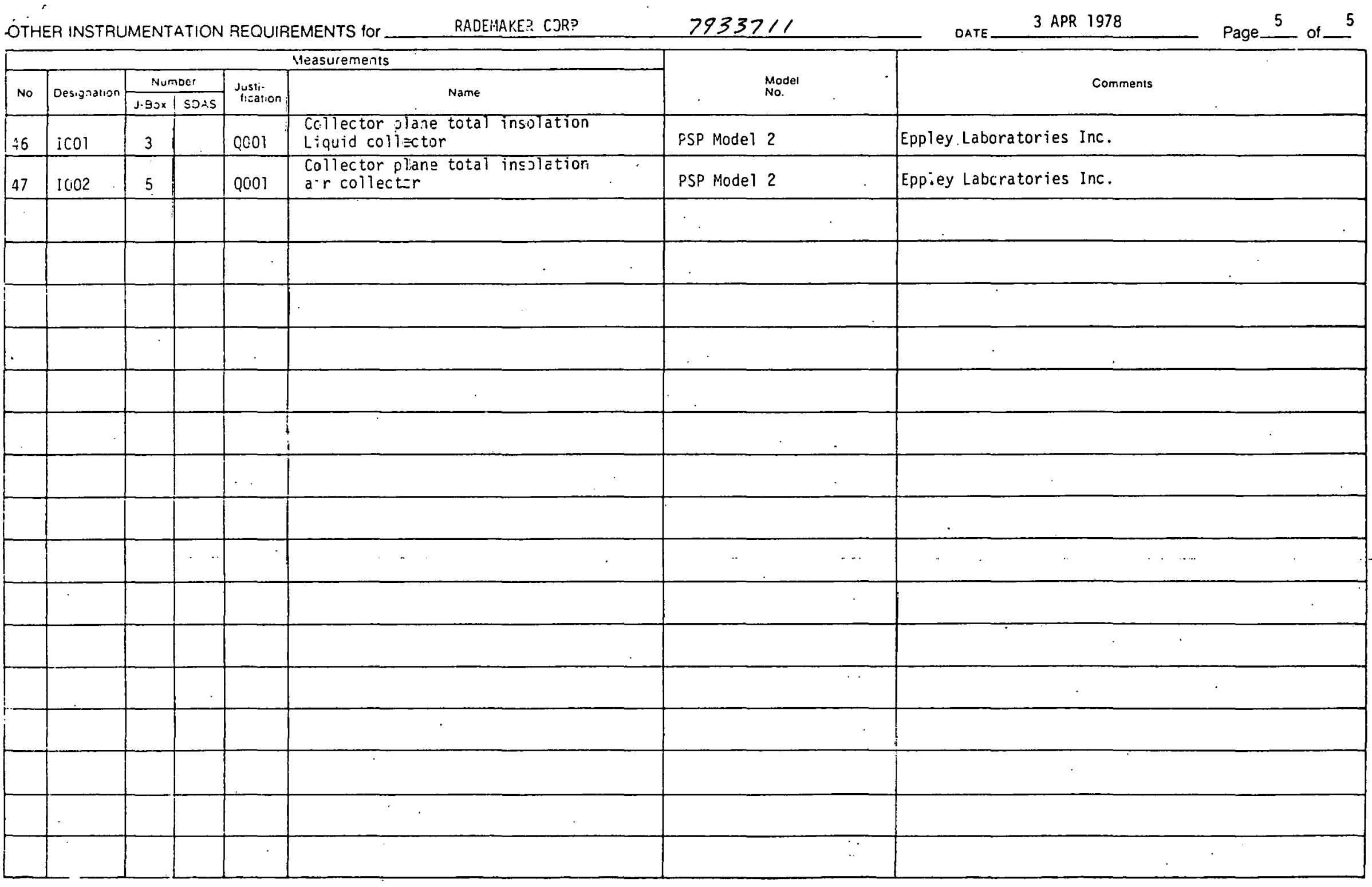

TABLE 2 
SECTION IV

ACCEPTANCE TEST 


\title{
ACCEPTANCE TEST PLAN \#1
}

$\underline{F O R}$

SOLAR HEATING SYSTEM

RADEMAKER CORPORATION

LOUISVILLE, KENTUCKY

\author{
Performed $7 / 3 / 78$ \\ by \\ Thomas Empson and Harry Sladen \\ of \\ Rademaker Corporation
}

A. LIQUID COLLECTOR SYSTEM (Refer to Drawings 76-241-2 and 76-24l-4)

Check

Column

1. Place the master liquid solar heat switch into the "Automatic" position. Note water temperature below center of tank at point where sensor TL-8B is located. Hawthorne controller TL-8A should allow cycleing of the glycol pump, provided collector sensing element is $15^{\circ}$ higher than tank sensing element temperature. Check this in early morning prior to the time when collectors are warm and glycol pump should be off. When unit cycles on, note water temperatures entering tank heat exchanger and see if unit cycles off as glycol temperature exceeds tank temperature. If it does; this circuit is not performing satisfartorily.

2. Place the main office heat switch in the "Automatic" position. Raise the setting of the room thermostat in the perimeter zone. The valve serving the water coil for this zone (V2) should open at the same time the hot water circulating pump (P2) should start. Valve $V 4$ in the glycol circuit serving the preheat coil 
for the perimeter zone should also open, provided the bulb thermostat $\mathrm{TL}-4$ in the return glycol 1 ine is sensing above $125^{\circ}$. If the stat is not causing this valve to open, drop the setting of TL-4 to assure that the electric circuit is functioning correctly and will allow the glycol valive to open when the return glycol temperature is acceptably warm.

3. Place the drafting rüm unil heding switch in the "Automatfc" position. Thermostat $T-10$ in the Drafting Room, if raised above room temperature, should allow the valve $(V-3)$ to open and pump P-2 to start at the same time. Likewise, the fan should start at the same time, allowing heat from the unit to the Drafting Room.

4. Take the temperature of the water in the domestic hot water storage tank. Preferable check-out should occur when the water tank is approximately room temperature and when the glycol temperature is above $120^{\circ}$. This would then allow the domestic hot water differential control ( TL-11) to cycle the domestic hot water pump $(P-3)$ and, lat the same time, to open the domestic hot water glycol valve $(V-1)$ to allow introduction of heat to the heat exchanger serving the domestic hot water from the glycol circuit. Observe the temperature of the water in the storage tank and, as it rises above the glycol circuit temperature, it should shut off the glycol valve $(V-1)$ and stop the domestic hot water circulating pump $(P-3)$. 
5. Note the Lapse Time Meter for Pumps $P-1, P-2$, and P-3, and the pilot lights for the three pumps and Drafting Room fan. Note to see if these function at the same time as the respective piece of equipment is energized.

6. Place the office perimeter zone gas heat switch in the "Automatic" position and raise the heating thermostat in the perimeter office zone. This should cause gas heat to come on to supplement the solar heating system. Both solar and gas can work together.

7. Place each of the respective system mode switches in the "Off" position and see if the respective system shuts down accordingly. Follow-up by placing the master liquid solar heat switch to the "Off" position and all respective switches associates with the liquid solar heating system should shut down, including the glyrn? pump.

\section{B. AIR COLLECTOR SYSTEM}

1. Place the master switch SA-1 in the "Automatic" position. This should allow the fan to start if the temperature sensed by the thermostat on the hot air collector $(T A-1 A)$ is $20^{\circ}$ greater than the temperature at the bottom of the rock storage box, as sensed by TA-1B. Assuming that the respective system switches are a11 in the "Off" position and the summer override switch is in the "Automatic" position, and provided heat exists at the hot air collector, Damper. \#4 should be opened and Damper \#3 should be opened, with all others being closed. This allows the fan to charge the rock storage with heat from the collectors. 
2. Place the interior office heating switch to the "Automatic" position and adjust the thermostat from this zone (TA-2) to call for heat. This should close Damper \#4 and open Damper \#7 which allows the introduction of heat to the interior zone. See Damper Schedule for ease of determination of respective damper position. This schedule is on Drawing 76-241-2.

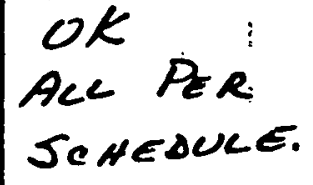

3. Reposition the interior office switch to the "Off" position and place the main office heat (perimeter zone) to the "Automatic" position. Raise the setting of the room thermostat serving the perimeter zone (thermostat TL-5). This should allow Damper \#1 to open. It should be noted at this point that if the collectors are putting out heat as previously described, Damper \#2 will be opened, Damper \#3 will be closed under this situation. However, if the collectors are not warm and if the rock storage has heat within it as sensed by Thermostat TA-3, Damper \#3 will be opened and Damper \#2 will be closed, allowing heat to be introduced from the rock storage. Again, refer to the Damper Schedule and see if the dampers are in the proper position.

4. Now, with all air system switches in the "Off" position (except the warehouse zone), place this one in the "Automatic" pnsition. namper \#5 should open to allow heat to enter the warehouse, provided the room themilostat in the warehouse (TA-6) is calling for heat. Again, check the Damper Schedule to assure that all dampers are assuming their proper position.

OK

ACL PER Semesuce. 
It is necessary to check each of the zone operations with the hot air collector in operation during the day and, likewise, during the period when no heat is available in the collectors and heat is already stored in the rock storage. Under each situation, the Damper Schedule should be carefully noted. Likewise, the pilot lights should be observed for each respective damper and the fan to determine if the pilot lights are giving a -rue indication of the operating mode. Also, note the Lapse Time Meter which operates when the fan is in operation to determine the number of hours used correctly.

5. Place the summer override switch in the "Summer" position and check to see if dampers have assumed the positions indicated in the Damper Schedule, namely, that Damper \#8 is opened allowing venting by gravity without the fan operation.

6. During the checking of each damper sequence, the exact travel of each of the dampers should be observed to assure that tight shut-off is accomplished and that full opening is accomplished by each respective damper motor. This will prevent overheating of any single zone to the linkage. Also, check temperatures of air being introduced to each respective zone to get a general idea of the uulpul capability of thr rnllectors and/or the rock storage system as relates to that respective zone.

7. Cienerally observe the systeIII lu assure that heat is not being dissipated from the system to the outdoors through the collectors.

ACE OK

ExCEPT 1 WHICH CEAK: AROUND PERT meter SLIGNY New Dampre NECDED.

OK 
This can be noted easily by watching the temperature of the air at the fan discharge when it is drawing from the collectors. If, at any time, the temperature drops below the temperature in the rock storage, which is usually ambient temperature (approximately $70-75^{\circ}$ ), then the system is dissipating heat instead of collecting it. The probable cause of this would be an inoperative or miscalibrated differential temperature control. A similar check should be made by observing the differential control function for the glycol loop with the reference temperature being the temperature of the water at the lower quarter of the tank. It should be noted that the glycol pump may occasionally stop, whereas the air system will continue to function. The reason for this is that the water storage temperature may have raised to a point where the glycol loop would be dissipating heat instead of absorbing it, whereas it is not likely to happen on the air system because the ambient condition of the rock near the bottom of the rock stack will seldom rise above $75^{\circ}$. This is due to the residual effect of the rock as it absorbs heat at the top of the stack and offers wide gradient between top and bottom, whereas the water temperaţure tends to be somewhat more even from bottom to top. 


\section{ACCEPTANCE TEST PLAN \#2 \\ FOR \\ SOLAR HEATING SYSTEM \\ RADEMAKER CORPORATION \\ LOUISVILLE, KENTUCKY}

This test plan was developed to evaluate the instrumentation in both solar heating systems at the Rademaker Corporation installation. These tests will be coincident with at least two Site Data Acquisition Subsystem (SDAS) scans (640 seconds) to permit the recording of measurements under essentially steady-state conditions.

I. Air Collector Solar Energy Heating System Tests

Time

Accomplished Juty 4, 1978

A. Solar energy available at collectors (TA-1A, 1B)

1. De-activate both solar heating systems including air handling unit (AHU) fans as well as all load switches and thermostats.

$8: 10$ a.m.

2. Activate $A H U$ fan for interior zone $(F-4)$.

$8: 20$ a.m.

3. Activate AHU fan for perimeter zone $(F-3)$.

$8: 30$ a.m.

4. Activate air collector solar heating system (SA-1).

$8: 40 \mathrm{a} . \mathrm{m}$.

5. Demand heat by warehouse (SA-4, TA-6).

$8: 50$ a.m.

6. Demand first stage heat by perimeter zone (SA-3, T-5)

9:00 a.m.

7. Demand heat by interior zone (SA-2, TA- ).

B. Solar energy availabie oniy in sturage (TA-3).

1. De-activate both solar heating systems including air handling unit (AHU) fans as well as all load switches and the rmostat.s.

$9: 20$ a.m.

2. Activate AHU fan for interior zone $(F-4)$.

$9: 30 \mathrm{a} \cdot \mathrm{m}$.

3. Activate AHU fan for perimeter zone $(F-3)$.

$9: 40 \mathrm{a} \cdot \mathrm{m}$.

4. Activate air collector solar heating system (SA-1).

$9: 50 \mathrm{a} . \mathrm{m}$. 
5. Demand heat by warehouse $(\mathrm{SA}-4, \mathrm{TA}-6)$.

6. Demand first stage heat by perimeter zone (SA-3, T-5), 10:00 a.m.

7. Demand heat by interior zone (Sa-2, TA- ).

$10: 20$ a.m.

C. Solar energy not available.

1. De-activate both solar heating systems including air handling unit (AHU) fans as well as all load switches and thermostats.

$10: 30 \mathrm{a} \cdot \mathrm{m}$.

2. Activate AHU fan for interior zone $(F-4)$.

10:40 a.m.

3. Activate AHU fan for perimeter zone $(F-3)$.

10:50 a.m.

4. Activate air collector solar heating system (SA-1).

$11: 00$ a.m.

5. Demand heat by warehouse (SA-4, TA-6).

$11: 10$ a.m.

6. Demand first stage heat by perimeter zone (SA-3, T-5) 11:20 a.m.

7. Demand heat by interior zone (SA-2, TA- ).

$11: 30$ a.m.

8. Demand second stage heat by perimeter zone (SA-3, T-5)

II. Liquid Collector Solar Energy Heating System Tests

A. Solar enengy available at collectors ( $T-8 A, 8 B$ ).

1. De-activate both solar heating systems including

AHU fans as well as all load switches \& thermostats. 11:40 a.m.

2. Activate liquid collector solar heating system and AHU fan for perimeter zone (S-1).

$11: 50 \mathrm{a} \cdot \mathrm{m}$.

B. Solar energy available only in storage (T-7).

1. Demand first stage heat by perimeter zone (S-3, T-5). 12:00 p.m.

2. Demand heat by drafting room $(S-4, T-10)$. $12: 10$ p.m:

C. Solar energy not available.

1. Demand heat by drafting room. 12:20 p.m. 
2. Demand first stage heat by perimeter zone (S-3, T-5) $12: 30 \mathrm{p} . \mathrm{m}$.

3. Demand second stage heat by perimeter zone $(S-3, T-5)$, 12:40 p.m. TEST FINISHED $12: 50$.p.m.

*Numbers in parentheses refer to designations of switches and thermostats. 
July 19, 1977

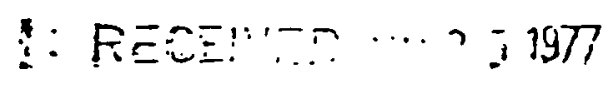

Raciemaker Corporation

2400 hatterson Trail

Louisville, Kentucky

Attention: Mr. Richard W. Rademaker

Reference: Our Telecon of July 19, 1977

: Geritlemen:

The faripump test we are requesting involves operation of your system in the following states. Each state should be mainitained for at least ten (10) minutes and the start time of each tesi state should be recorded. Also, please record the camper and välve positions appriopriate for each stäte. F. desirât.le mode in which to perform the test would be Mode I - "Heat From Coilector to Ferim:ter Sy'stem"

Done 8-23-77

\section{State 1}

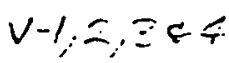

Closer

PI (Coilector Loop Pump) - ON
FI (Collector Loop Fan) - ONI START $3: 45$ EDT
STOP $3: 55$ EDT

\section{State 2}

$D M 2 \times 4$ STATE $1-2-3.4$ $D M * 3,5,6=5$ STATE 5

$V-3$ Cirew PI and P2 (Loaci LoOp Tump) - ON

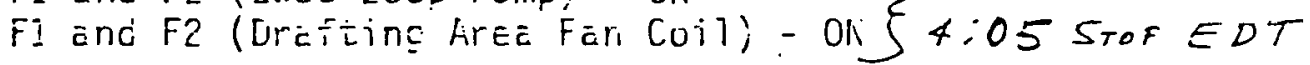

\section{Stitie 3}

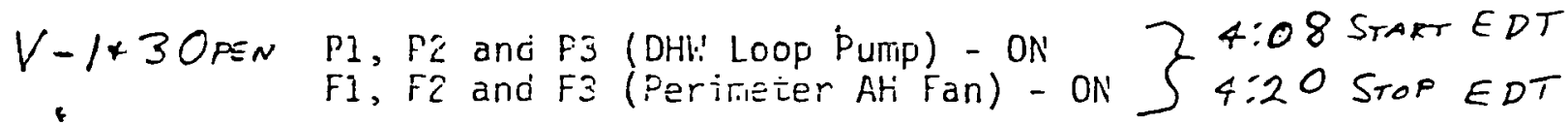

\section{Stiotese}

V-IOPEn
PI only (DHW LOOP Pump) - ON

\section{Stàte 5}

F3 FG, both = ON (note which epplies) $\rightarrow 4: 38$ STAPT EDT No Pumps Runing 
SECTION V

INTERIM PERFORMANCE CRITERIA CERTIFICATION 
DEATARER CORPORATION 24GN WATTETSON TRAIL

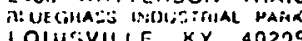
LOUISVILLE. KY. 40239
(S02) 267.9630

\section{August 27,1975}

National Aeronautics \& Space Adininistration George C. Marshall Space Fi ight Center

Marshall Space Flight Center, Alabana $250 \mathrm{~S} 2$

Attention: Mr. Thomas Lavicison, FA33

Sibject: Contract $E(49-i \varepsilon) 2335$

\section{GentTemen:}

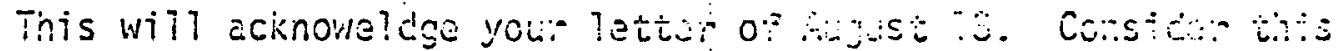

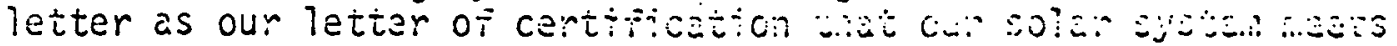

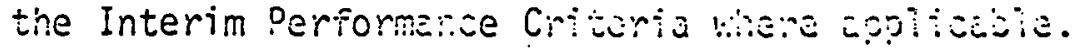

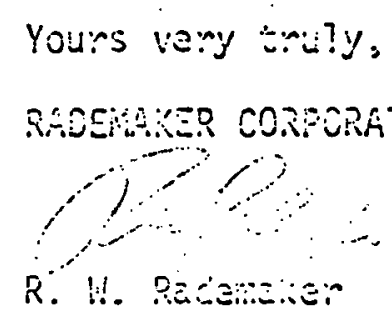

Presidato

$R: R / D$ 


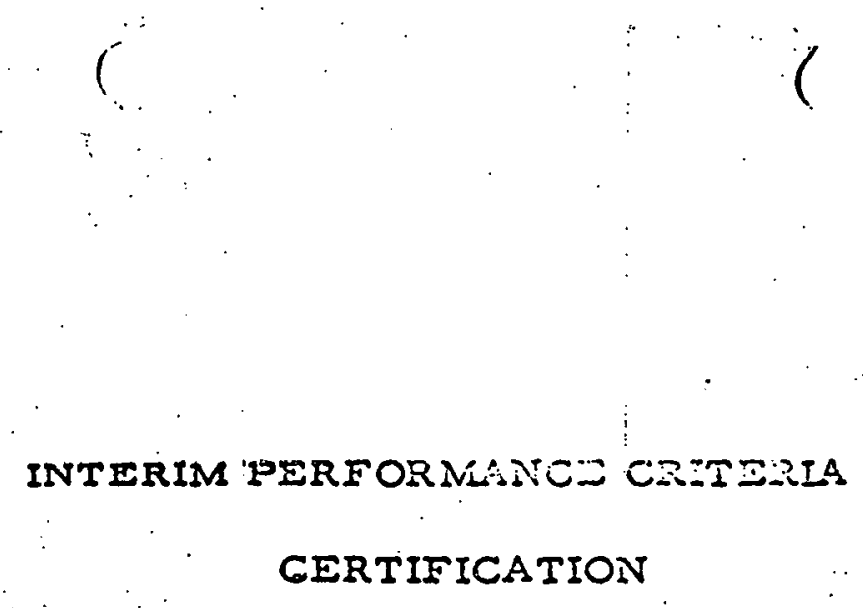

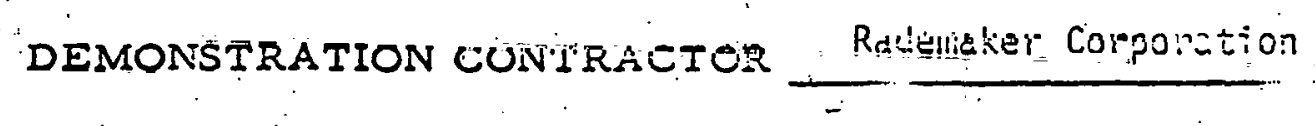
SYSTEM LOCATION Louisvil!e, Kanticky

SYSTEN TYPE Space Heating and Domestic Hot Hater Hating

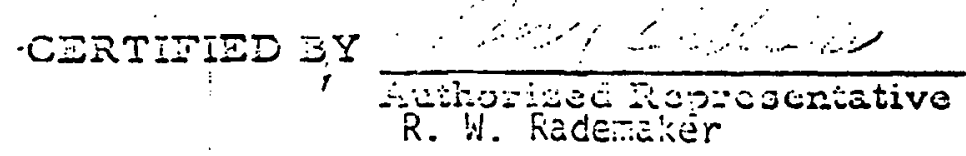
DAm Rusis: 20,1976 
SECTION VI

UPDATED KEY INFORMATION FROM ORIGINAL PROPOSAL 
UPDATED KEY INFORMATION FROM ORIGINAL PROPOSAL:

One of the primary aims of the installation was to determine the comparative results of the air system versus the liquid system operating under a similar environment. Since the system has currently been operating through two winters, a considerable amount of information has become available to the writer as a result of observation even without detailed information from the monitoring system. First of all, there is relatively little difference in the apparent performance of the air system and the liquid system due to their variation in tilt angle. It appears that the air system responds more readily to the diffuse radiation situation which is partly because it is oriented more flatly and, secondarily, because it is operating with respect to a lower reference temperature.

Experiments have been conducted using a reflector on one of the collectors which is very easy to see on the photographs accompanying this presentation. It is apparent that during clear days (heavy direct insolation), the reflector has a significant added benefit during summer cycle of operation with tempcratures being as much as $20^{\circ}$ higher with the same flow. The system was installed with separate circuits from each respective collector so that results such as this could be easily obtained.

It was thought when the system was designed that the glycol preheat coil would serve considerable value for extracting the maximum heat from the liquid system. In actual practice, however, it is observed that the heat from the glycol is extracted within the tank due to the fact that the demands upon the system are always heavy with respect to the insolation. In other words, the heat is being demanded as fast as it can be absorbed by the collectors. The temperature of the glycol relatively always stays below the $120^{\circ}$ temperature which was set as the point at which glycol could pass through the preheat coil prior to reentering the collector loop. When it is allowed to enter this preheat coil at a lower temperature, it drops the whule lemperature threshhold of the storage and thereby merits nothing to the systeiin.

It should further be noted that additional surface was added to the heat exchanger within the storage tank after the system had been placed in operation the first year since it was obvious that heat transfer was not sufficient during static conditions. 


\section{SECTION VII}

MAJOR MAINTENANCE AND CONSTRUCTION

PROBLEMS ENCOUNTERED AND RECOMMENDATIONS 


\section{MAJOR MAINTENANCE AND CONSTRUCTION PROBLEMS ENCOUNTERED AND RECOMMENDATIONS}

Generally, there were some problems encountered and they are listed herein.

1. Glazing Problem

The Kalwall applied to the SDI collectors degraded rather heavily during the first summer and winter. It was replaced in the early summer of 1977 and went through the second winter with considerable improvement. Apparently, the Kalwall Premium II is better than the original Kalwall. Likewise, the glazing on the Solaron collectors showed a white deposit between the layers of glass after the first winter of operation. This glazing was replaced in 9 of the 10 panels at the same time the above mentioned glazing was replaced. The new glazing appears to have less of a problem, however, some evidence of white deposits has reoccurred after about 14 months. The condensation between the layers of glass has not been eliminated. The writer has concluded that it is very nearly impossible to eliminate this problem, no matter how caretuliy the instructluns of the manufacturcr arc followed.

2. Insulation

The Armaflex insulation used on the outside of the building tended to stiffen up and show considerable degrading during the first summer and winter. During the summer of 1977, the Armaflex was covered with a fiberglass insulation and then the complete insulation package was covered with a plastic material and sealed at all joints. Likewise, cans were placed over the edges of the insulation to assure that no water could get through to reduce the value of the insulation. The net result was considerable gain during the next winter's operation. The recommendation of the writer would be not to use Armaflex outdoors. It works quite satisfactorily indoors. The manufacturer's paint applied to that which was outdoors did not appear to make much difference. The degrading still occurred.

3. Controls

Problems occurred with the differential temperature contrut devices which are

- manufactured by Hawthorne. The units originally installed tended to stutter upon start-up and shut-down causing the fans and pumps respectively to chatter at start-up and shut-down. This was solved by the introduction of time-delay relays in the circuits. Likewise, the manufacturer sent replacement units which still seemed to have the same problem occasionally. Time-delay relays are recommended to eliminate this occurrence.

4. Glycol

A freeze-up with $20 \%$ glycol solution used temporarily during the first winter proved to be evidence that it is desirable to use a greater percentage of glycol. $40 \%$ glycol solution is recommended for this part of the country. The problem did not occur due to pipes bursting as a result of freezing, but, instead, failure of the liquid to flow through the pipes even though the sun had increased the temperature of the liquid at the collectors to the point 
4. Glycol (continued)

where it would melt below the slush point. Failure of the liquid to flow caused glycol to be ejected through a gasket in one of the motorized valves due to increased pressure when the relief valve was isolated due to the presence of slush. No problem has occurred with respect to this since the $40 \%$ glycol was installed prior to the second winter.

5. Maintenance

Practically no maintenance problems have occurred with either of the systems other than those items outlined above. Generally, the air system is shut down during the summertime since the slight leakage of the dampers entering each of the two air handling systems causes an added load to the air conditioning system. This leakage does not seem to be a problem during the winter, however, the writer does intend to replace the damper \#1 serving the outer zone since that leakage is more evident and the use of a tighter seal damper will make the job a better one. 


\section{SECTION VIII}

OPERATION AND MAINTENANCE MANUAL 


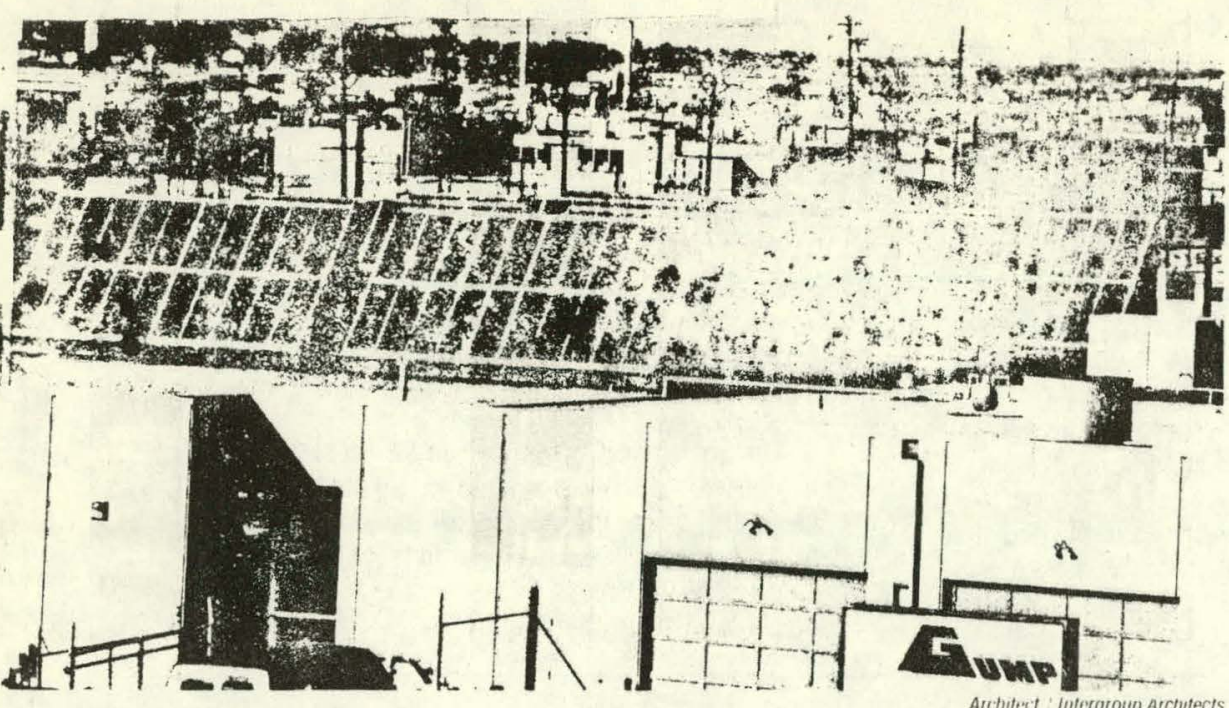

Space Heating / Domestic Water Heating Make-Up Air Heating / Process Water Heating
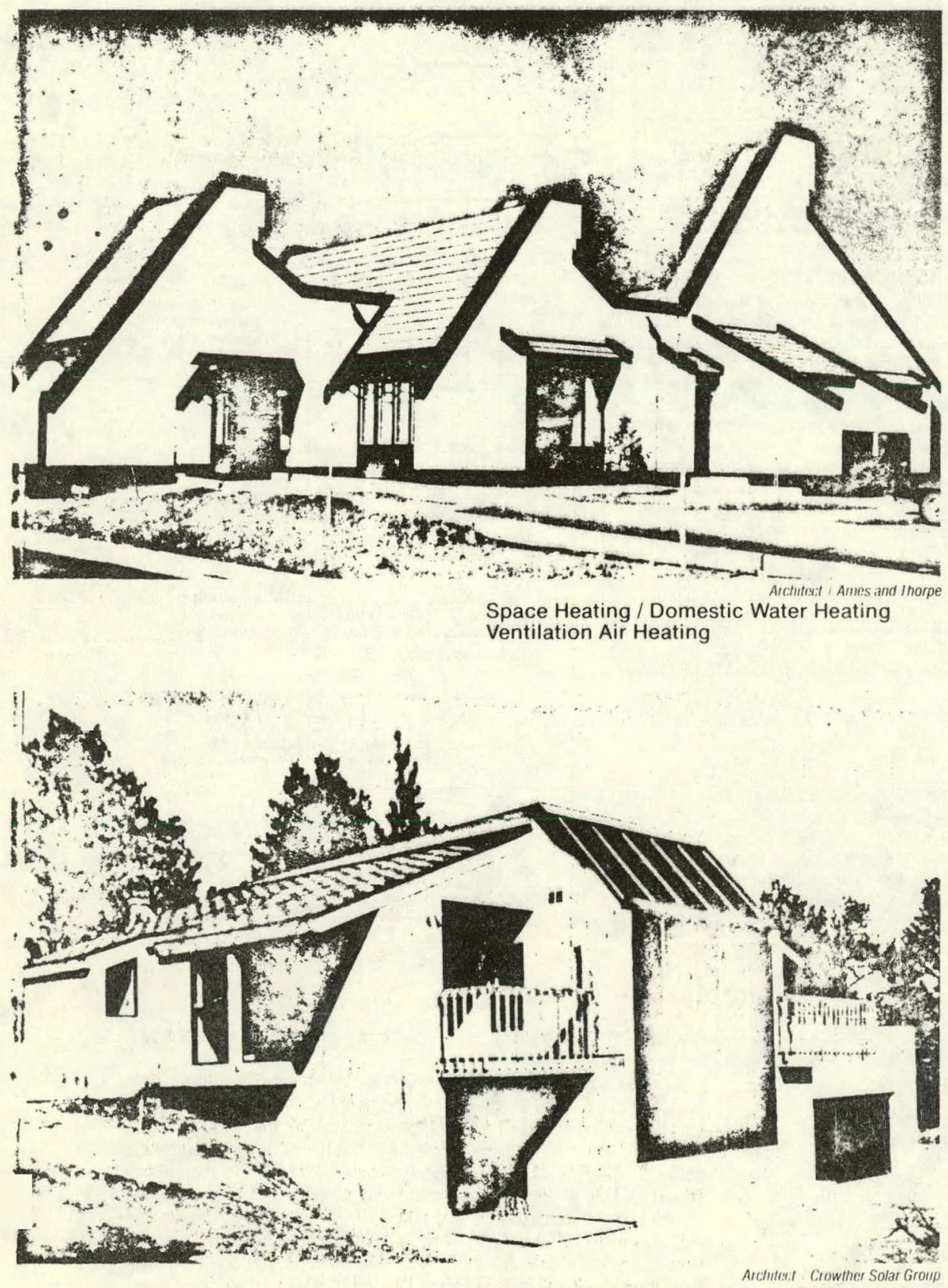

Forced Air Space Heating / Pool Water Heating Domestic Water Heating

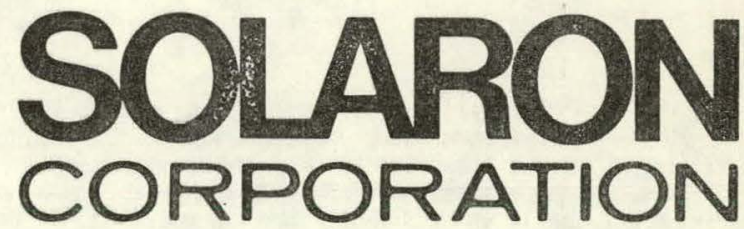

Solar AIR heating systems produce more usable energy than liquid solar systems. An independent test of side by side air and liquid solar systems at Colorado State University states: ". . . the air system operated 45 percent longer during the day than the liquid system and collected 38 percent more heat." "This is a consequence of stratified heat storage in the pebble bed for the air system and nearly uniform temperature in the water storage tank of the liquid system." This is described in terms of the solar system performance equation on page four of this brochure.

The SOLARON AIR COLLECTOR effers the following advantages:

- 10 Year performance warranty.

- Safe, reliable and virtually maintenance-free operation.

- Freedom from damage by freezing or boiling.

- Absence of pipes which can corrode and leak.

- Requires no antifreeze or stagnation pressure relief controls:

- Approved by HUD and ERDA for Federally funded projects.

MR-MANUFACTURER

Solaron's business is the practical application of solar energy. We design, manufacture and market solar heating systems for industrial, commercial, agricultural process drying and residential buildings. The heart of our system is the air-type solar collector, a design based on over 30 years research and development by Dr. George Lof. To contact the nearest Solaron dealer, call the SWEETS BUYLINE.

Design Assistance: Solaron has a complete design manual covering all aspects of solar system engineering, architectural requirements and economics. Contact Solaron for a copy of the design manual. Experienced and technical personnel are available to assist on any special applications. 


\section{The Solar Air Heating System}

The Solaron solar heating system is marketed throughout the U.S. by local distributors and dealers who are well established in the HVAC industry. The Solaron distributors maintain a complete stock of Solaron equipment. The distributors, who also handle major brands of heating and air conditioning equipment, work with dealers who are HVAC installing contractors. The Solaron dealers are established and reliable contractors who are familiar with installing heating equipment and associated ductwork. Both the distributors and dealers are thoroughly trained by
Solaron in all aspects of solar heating, design, equipment application and installation. Solaron engineers and field servicemen support the distributors and dealers as required, and provide on site assistance.

The Solaron collector, air handler and controller and necessary ductwork is installed by the HVAC contractor. The general contractor usually builds the heat storage container. The system is then tested through all of the operating modes and thoroughly checked for proper operation.

OP-OVERALL PRODUCT, IN PLACE

\section{SYSTEM OPERATION}

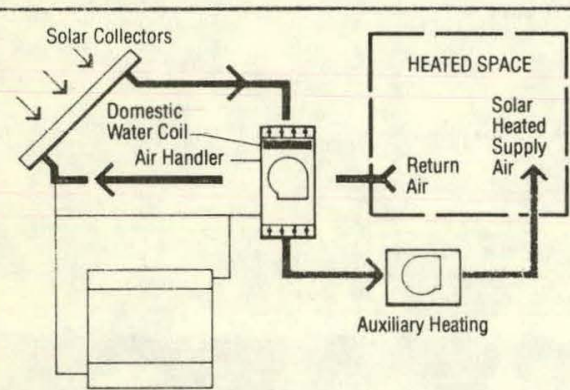

HEATING FROM COLLECTOR Air, the circulating heat transfer medium is drawn through the collector where it is normally heated to about $120-150^{\circ} \mathrm{F}$. When the space requires heat, the solar heated air is drawn through the air handling unit in which motorized dampers are automatically opened to direct the hot air to the space. The air then returns to the collector where it is again heated and the cycle repeats itself.

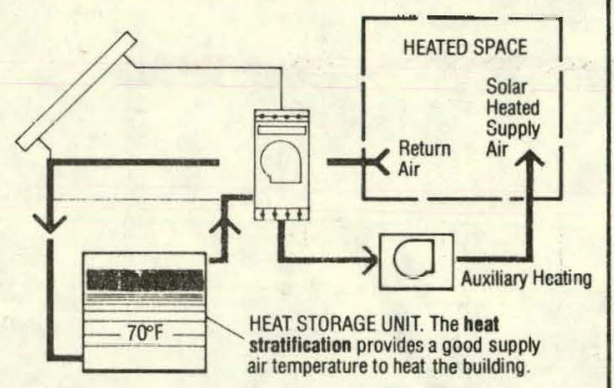

HEATING FROM STORAGE At night or on cloudy days when solar energy is unavailable and when heat is needed in the space, the automatic control system directs the building return air into the bottom of the heat storage unit, up through the pebbles where the air is heated, through the air handling unit and into the space. When the solar heated air does not maintain the space thermostat setting. the automatic control turns on the auxiliary heater to add to the required heat.
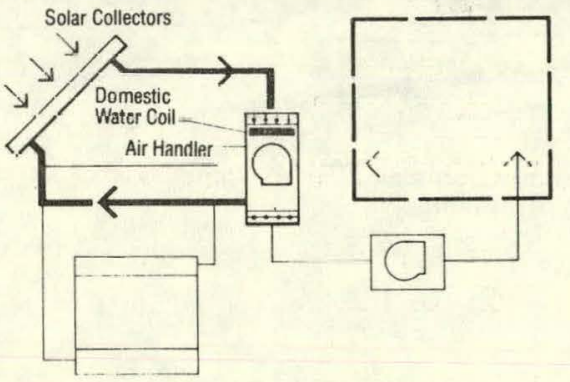

SUMMER WATER HEATIMG In the sUmmer, when space heating is not required, air is drawn through the collector where it is heated and then through the water heat exchanger coil. The solar heated air transfers its heat to the water which is being circulated through the coil and the air is then returned back to the collector inlet.
TYPICAL COLLECTOR ARRAYS

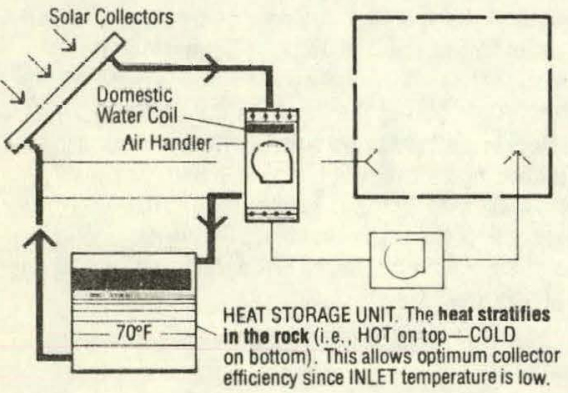

STORIMG HEAT When the space temperature is satisfied the automatic control system diverts the air into the heat storage unit where the heat is absorbed by the pebble bed. The air returns to the collector where it is heated and this cycle is repeated.

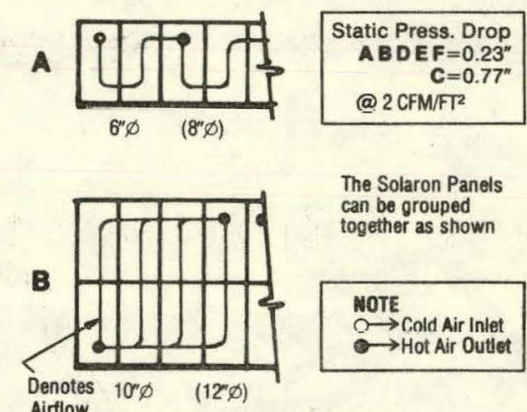

Denotes

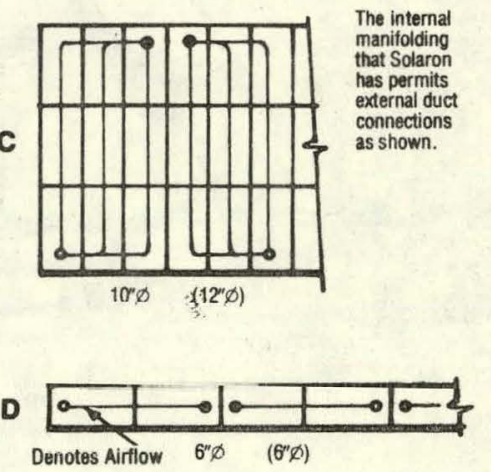

E
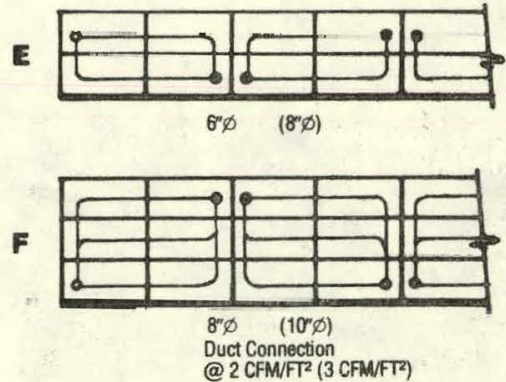

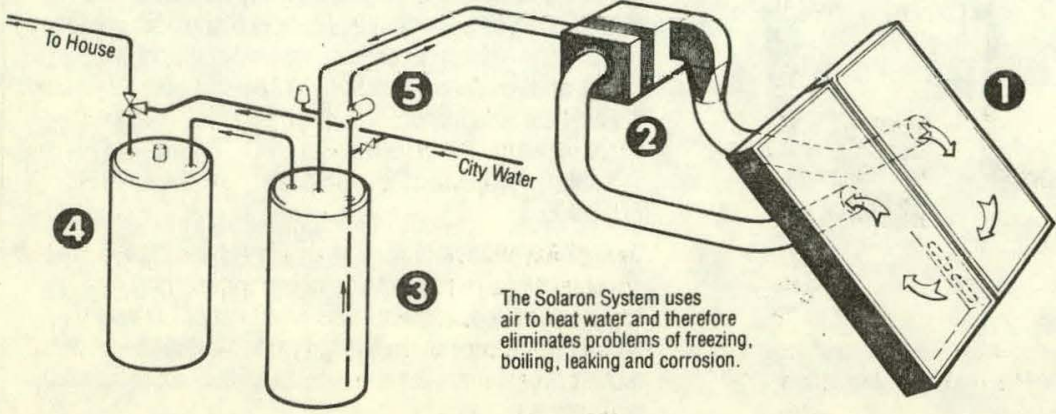

64

\section{SOLARON DOMESTIC WATER HEATING SYSTEM}

The Solaron Domestic Water Heater System involves a very sımple operating cycle. Solar energy is collected by the south facing collector $\mathbf{1}$. Air is circulated by the heat exchange unit $\mathbf{2}$ where the solar energy is transferred to the water being circulated by the domestic water circulating pump 5. Solar heated water is continuously circulated into the storage tank 3 as long as the Solaron control unit indicates that solar energy is available at the collectors 1 and until tank temperature in the storage tank 3 reaches 160 degrees $F$. When hot water is required water is drawn from the conventional domestic hot water heater 4 and preheated water is drawn from the storage tank $\mathbf{3}$ into the conventional domestic water heater. 


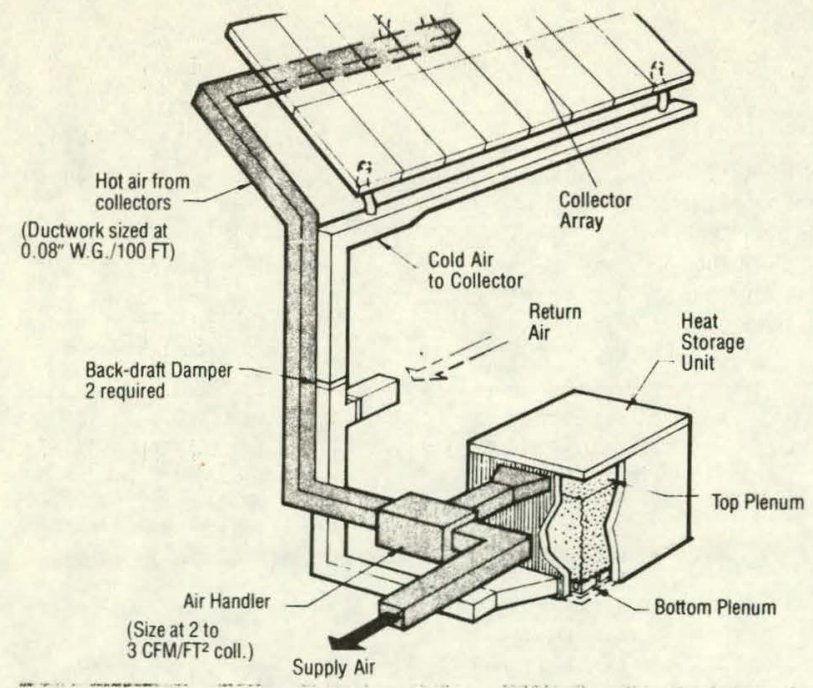

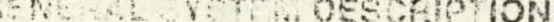

A drawing of a typical installation is shown to the left. The collectors can be grouped as shown or in any of the configurations shown on page 2. Typical Collector Arrays. Due to the Solaron internal manifolding technique (i.e. air flow from one panel to another internally) the external duct connections are minimized as shown above (i.e. one inlet and one outlet for 8 panels, $156 \mathrm{ft} .{ }^{2}$ ). This technique reduces field labor and leads to an economical installation.

\section{CONTACT SOLARON TO OBTAIN SYSTEM SCHEMATICS SHOWING HOW TO COMBINE SOLAR HEATING WITH:}

- Heating \& air conditioning

- Heat pumps

- V.A.V. systems

- Multiple zones

- Process water heating
- Make-up air heating

- Process air htg-drying

- Swim pool water htg.

- Industrial \& agricultural heating

\section{CP-COMPONENTS, PARTS}

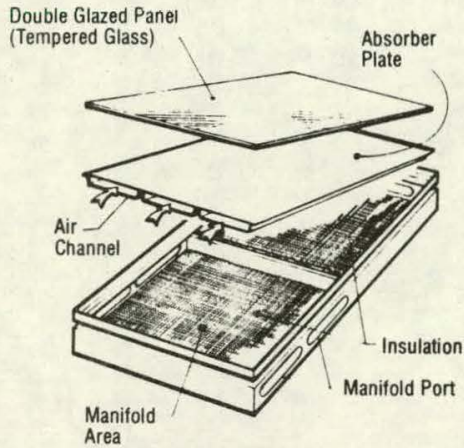

Note: Air flows thru the channels

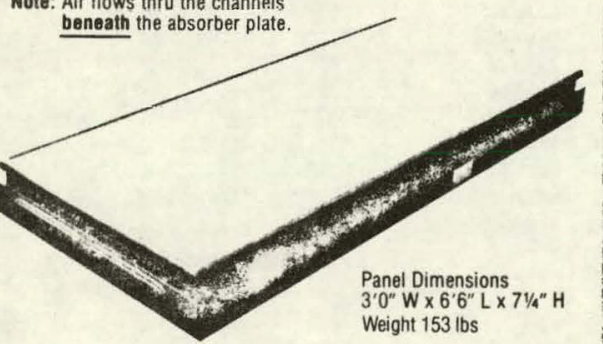

Q $\triangle R O N C O L L$ TOE $\triangle A N E$

DETAILS (patents applied for)

The Solaron solar collector is an advanced type of an air heating, flat plate collector. Our exclusive internal manifolding allows the Solaron collector to be completely modular. Factory preassembled collector panels are plugged into each other with a minimum of installation time. Air inlets and outlets are field cut into each collector array as required. The Solaron solar collector is designed for installation on any structurally sound surface, such as a roof, wall or specially made supports.

The Solaron solar collector has the following general construction characteristics:

Absorber: 28 gauge steel with porcelain enamel coating.

Glazing: Two $1 / 8^{\prime \prime}$ sealed special low iron tempered glass panels with a long life EPDM perimeter gasket. Glass plate can be easily removed for service or replacement.

Pan: 20 gauge steel, fully insulated with $33 / 4$ " fiberglass batt. Painted external surfaces.

Connection Ports: Unique flange configuration permits tight air seal automatically as modules are installed.

Cap Strip: Painted steel designed to provide weather seal between panels.

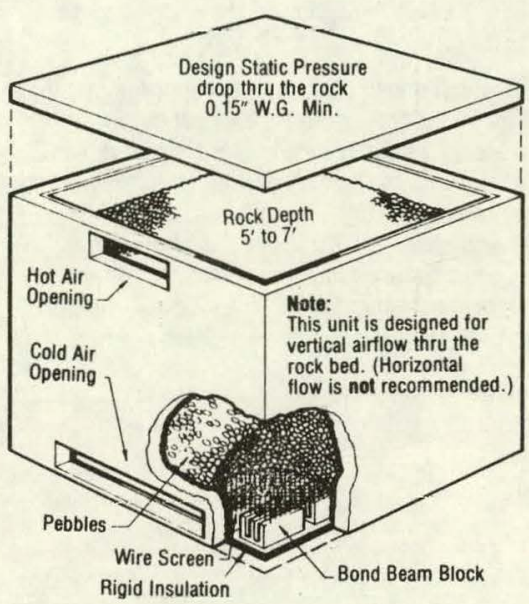

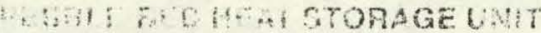

The use of pebbles in the heat storage unit is particularly effective with an air circulating solar heating system. The pebble bed maintains a steep temperature stratification (i.e. hot on top and cold on the bottom). This allows air to be provided at the highest available temperature to the heated space from the top of the pebble bed. It also allows air to return from the bottom of the bed to the collector at essentially room temperature. This ensures maximum efficiency of solar heat collection and delivery.

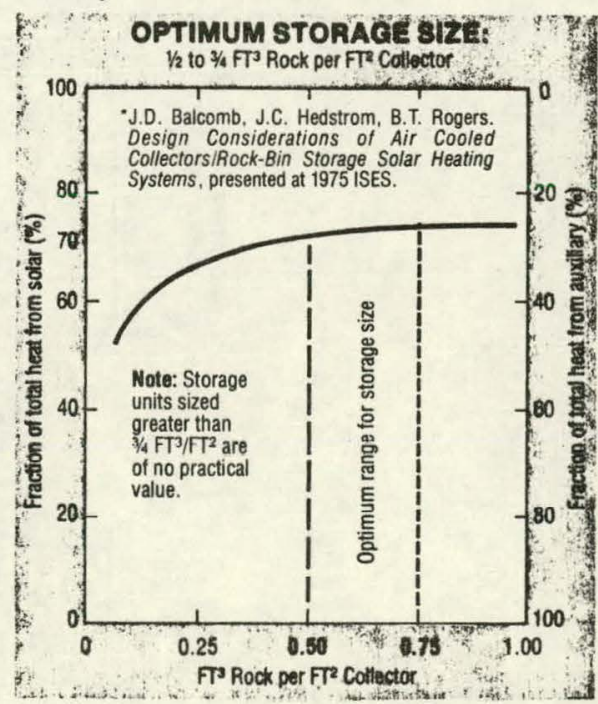

The heat storage unit must be built and installed by the local contractor to Solaron standard drawings and specifications. Contact Solaron for a copy of these specs.

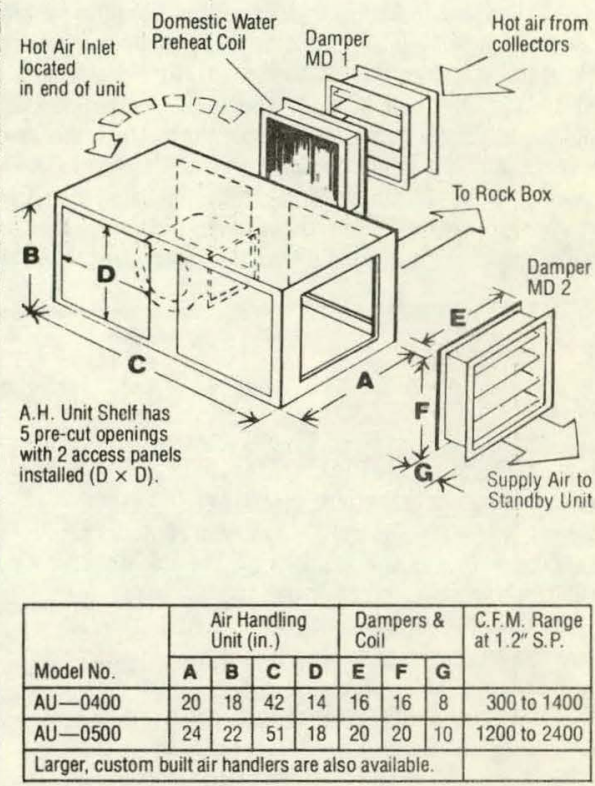

\section{AIR HANDL NG UNIT}

Solaron provides a standard factory preassembled air handling unit, including a blower, and motor driven dampers. A separate damper pair is furnished for mounting in the duct system, (i.e. backdraft dampers).

A typical installation for the air handling unit near the auxiliary heater and heat storage, is shown in the General System Description (upper left). The air handler can be mounted either vertically or horizontally, and with proper orientation and clearance to receive all connecting ducts without interference.

\section{SOLARON AUTOMATIC CON:FOL UNIT}

The automatic temperature control unit is included as part of the Solaron system. The controller handles all of the operational modes which are shown in the schematics on page 2. The controller operates the solar side of the system and ties into a 2-stage thermostat to provide solar and/or auxiliary heat to the space as required. The standard controller can be modified (with Solaron hardware) to combine with heat pumps or other types of auxiliary heating systems. Solaron can provide technical assistance to design special controllers for large projects or special applications. 
Comparison of varioustypes of solar heating systems can only be done properly if the entire solar system is evaluated over an entire heating season. Collector efficiency is an instantaneous point in time measurement and is not a valid parameter to evaluate the solar system performance. The ideal situation for a solar system is to keep the fluid inlet temperature to the collector as low as possible and have a high usuable temperature for space heating. Therefore, the ideal solar system has heat stratified in the storage unit. An air solar system using rocks as the thermal storage provides this stratification. Therefore, the inlet temperature to an air collector is typically $70^{\circ} \mathrm{F}$ where the liquid collector inlet temperature is $130^{\circ} \mathrm{F}$

$$
\begin{gathered}
\mathrm{Qu}_{\mathrm{A}_{\mathrm{c}}}=\mathrm{F}_{\mathrm{R}}\left[\overline{\mathrm{H}}_{\mathrm{I}} \tau \alpha-\mathrm{U}_{\mathrm{l}}\left(\mathrm{T}_{\mathrm{i}}-\mathrm{T}_{\mathrm{a}}\right)\right]={ }_{\mathrm{Ft} .^{2} \text { Day }}^{\mathrm{BTU}} \\
\text { gains L losses }
\end{gathered}
$$

Two collectors of similar construction can be compared using the performance equation. When the average collector inlet temperature ( $\left.T_{i}\right)$ is used, the liquid systems produce almost the same heat output as the air system.

$$
\begin{aligned}
& \text { AIR: } \begin{array}{l}
Q_{u}=0.69\left[(300)(0.75)-(0.8)\left(70^{\circ}-40^{\circ}\right)\right]=139 \\
A_{c}
\end{array} \\
& \text { LIQUID: } Q_{u}=0.90\left[(300)(0.75)-(0.8)\left(130^{\circ}-40^{\circ}\right)\right]=138 \quad \begin{array}{c}
\text { BTU } \\
A_{c}
\end{array}
\end{aligned}
$$

However, this is still an instantaneous point in time measurement which doesn't take into account the fact that the air system will typically collect for longer periods of time and therefore deliver more total heat output. When these systems are evaluated over an entire season, the results are as reported by the C.S.U. report \#COO2868-1. ". . . Because of the stratification, the temperature of the air returning to the collector from the bottom of storage is always near room temperature. Thus, the air collector can deliver useful heat from early morning to late afternoon: the liquid system starts up later in the morning and shuts off earlier in the afternoon ...

Therefore, when system performance is evaluated over an entire season it shows that AIR solar systems actually produce more usable energy than liquid systems. The C.S.U. tests report that the air solar system delivered considerably more heat output than the same sized liquid system right next to it.

* Ref. Hottel, H.C. and Woertz, B. B. A. S. M. E. Transactions 64. 911942 Pertormance of Hat Plate Solar-Heat Collectors.

1. Solar Collector Area: The collector area can be determined by using the Solaron Conversion Factors shown to the right. The design heat loss is divided by the S.C.F. to get $\mathrm{ft}^{2}$ of collector. Recommendations - Annual fuel savings for space heating should equal $30 \%$ to $70 \%$. Annual fuel savings for applications with a more uniform load throughout the year can be higher than $70 \%$.

2 Air Flow Rate: 2 SCFM to 3 SCFM per $\mathrm{ft}^{2}$ of solar collector area. Contact Solaron for special applicatinns sulch as make-up air heating, outside air heating for drying or industrial or agricultural process heatiny.

3. Heat Storage Size: $1 / 2$ to $3 / 4 \mathrm{ft}^{3}$ rock per $\mathrm{ft}^{2}$ of solar

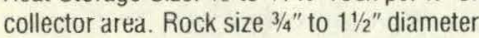

\section{SELECTION EXAMPLE}

Given that: $\Lambda$ commercial building with a design heat loss $136,800 \mathrm{BTU} / \mathrm{HR}$, the location is Denver. Colorado and the desired annual fuel savinys is $50 \%$.

1. Collector Area (Design heat loss) : (S.C.F.) $136,800 \div(171) \quad 800 \mathrm{ft}^{2}$ collector

2. FLOW Rate $=\left(2 \mathrm{SCFM}\right.$ per $\left.\mathrm{ft}^{2}\right) \times$ (Collector Area) (2) $\times(800)=1600$ SCFM

3. Heat Storage Unit $\left(1 \frac{1}{2} \mathrm{ft}^{3}\right.$ rock per $\left.\mathrm{ft}^{2}\right) \times($ Colletlur Area) $\quad(1 / 2) \times(800) \quad 100 \mathrm{ft}^{3}$ rock
Example: Project at $40^{\circ}$ N. Latitude. $500 \mathrm{ft}^{2}$ Collector Area

1. If Orientation is $20^{\circ}$ to the West: The relative collector area required to provide the same annual fuel savings as a system at due South is approximately 1.04 times the calculated collector area $(1.04)-(500) \quad 520 \mathrm{ft}^{2}$

2. The optimum collector tilt would be $45^{\circ}$ to $55^{\circ}$ (i.e. $L+3$ to $L+15$ )

If the collectors were at a tilt of $35^{\circ}$ (i.e. L 5) the relative collector area required would be $1.03 \times$ $500 f^{2} \quad 515 t^{2}$ If hnth ronditions exist (i e ?n' West \& $35^{\circ}$ tilt) the correction would be (1.04) $(1.03)(500)-5356 \mathrm{ft}^{2}$
Solar collector area $=\left(\right.$ design heat loss $\left.\frac{B T U}{H R}\right) \div($ S.C.F. $)=\mathrm{Ft}^{2}$

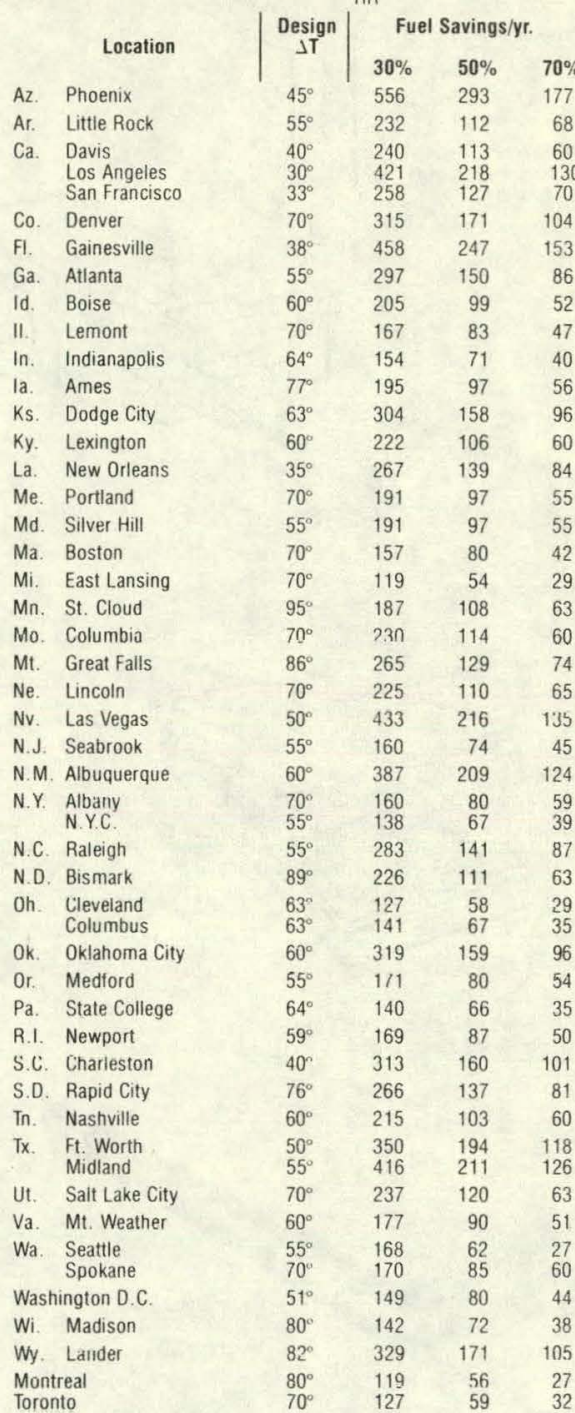

Note collector tilt $=53^{\circ}$

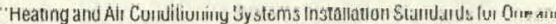
Two Family Dwellings and Multifamily Housing Including Solar." The Better Heating \& Cooling Bureau, SMACNA. Third Edition, Feb. 1977 Reprinted by permission.
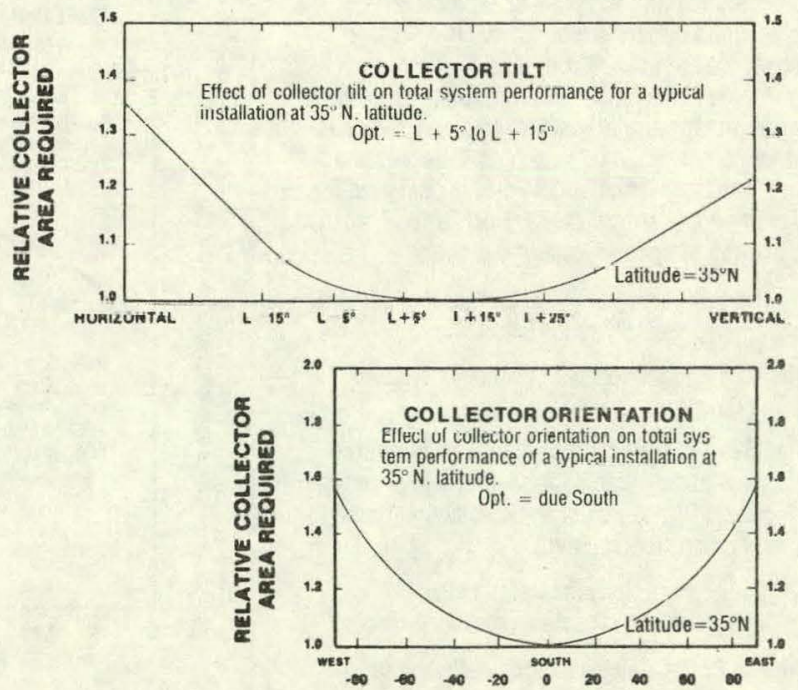

SOLARON CORPORATION 300 GALLERIA TOWER 720 SOUTH COLORADO BLVD. DENVER, CO 80222 (303) 759-0101 
For information on the Solaron Collector Panel Details contact Solaron Corporation, 300 Galleria Tower-South, 720 S. Colorado Blvd, Denver, CO 80222 . 


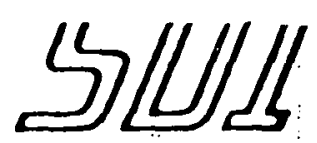

SOLAR DEVELOPMENT INC.

4180 WESTROADS DRIVE WEST PALM BEACH, FLORIDA 33407 TEL. 842.8935
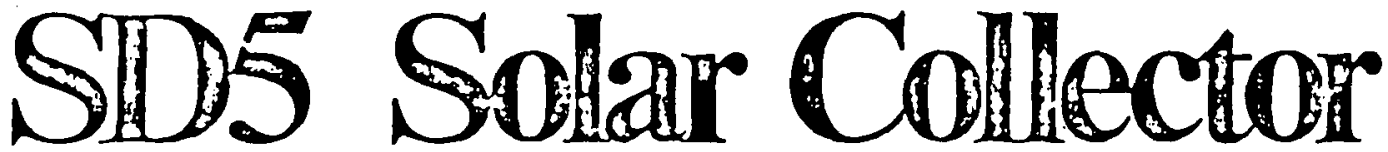

Shown for flat roof installation in South Florida. Sloplng roofs accommodated by adjustling rear strut length.

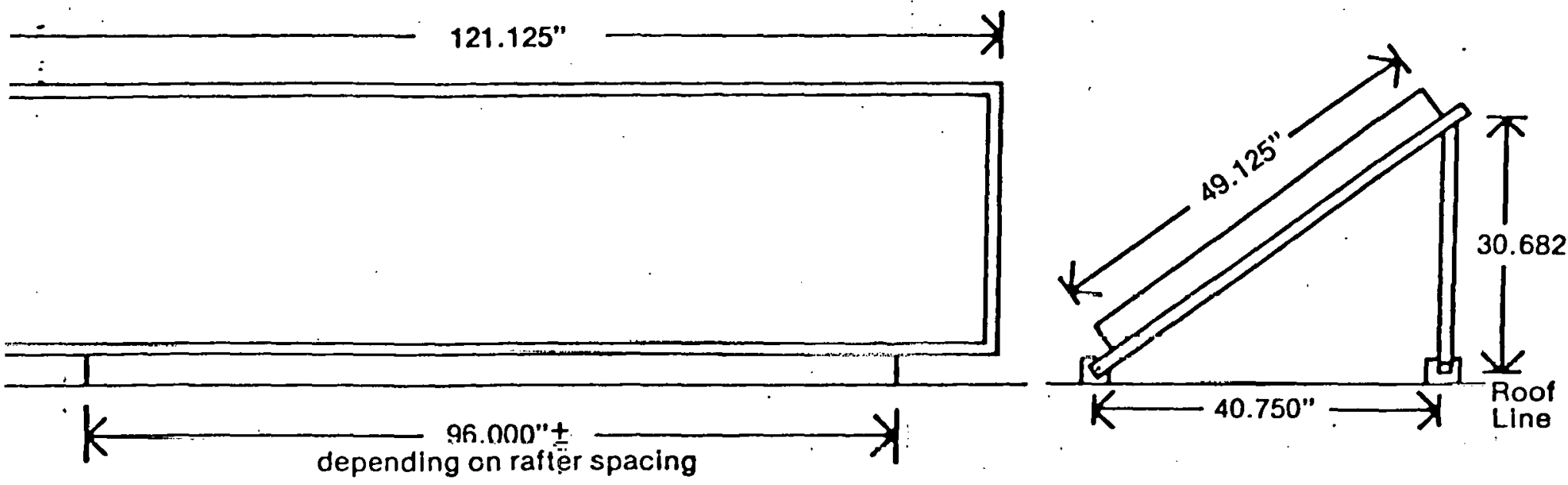

\section{TECHNICAL SPECIFICATIONS}

USES-water heating, space heating, and pool heating DIMENSIONS - 4' $\times 10^{\prime}$ nominal

WEIGHT - 140 lbs. including roof mounting hardware, 150 lbs. wet

COLLECTOR PLATE-.012" thick copper

PIPING - $100 \mathrm{ft}$. of $1 / 2 "$ copper $43 / 4$ " on centers, sinusoidal layout, parallel arrangement available by special order

PIPEIPLATE CONNECTION - collector-plate grooved to accept $1 / 2$ of pipe circumference for excellent heat transfer, $100 \%$ capillary flow solder bond.

BOX - extruded aluminum sides, .032" aluminum sheet backing

INSULATION -1" polyurethane (closed cell) or tectinlfoam isocyanurate

GLAZING - .040" Kalwall Sun-lite Premium. For double glazed northern unit, inner glazing $.025^{\circ}$ Kalwall Sun-lite Premium, outer .040"

WIND LOADING - designed for $30 \mathrm{lbs}$. /sq. ft.

VARIATIONS - collector can be manufactured in various lengths, widths, etc. to meet specific requirements

PERFORMANCE - the SDil collector has been tested by Desert Sunshine Exposure Tests, Inc., Black. Canyon Stage, Arizona using The National Bureau of Standards' Test Procedure. SDI has a computer program to predict performance under various condltions based on the results of this testing. Large installations can be designed optimizing tank slze and number of collectors.

\section{-Pricing* (F.O.B. West Palm Beach)}

- In the absence of a quotation, prices subject to change without notice.
PUMP \& CONTROLLER - for residential domestic water-use, pump, controller and check valve are mounted in one package. The controller uses two low voltage sensors to compare tank temperature to collector temperature and instructs the pump to circulate only. when energy can be added to the system.

PUMP - Mách 809, 115 VAC or Teel 1 P780

FLOW - $3 / 4$ to 1 g.p.m. depending on piping run. Pumps drawing up to 2 amps at 115 VAC may be substituted for multiple collector systems CONTROLLER FEATURES -

1. All solid-state industrial grade construction.

2. Custom aluminum enclosure with "irridited" and sealed finish.

3. Control box may be operated reliably from freezing to over 120 degrees Fahrenhelt.

4. Thermistor sensors will operate from 50 degrees below zero to 300 degrees above zero, Fahrenheit.

5. Sensors isolated from high voltage... sale 9 volt signal. . . no conduit or electrician required.

6. One ycar guarantee.

7. Operating cost less than one cent per 10 hour day, including Dump.

Solar Collector with Roof Mounting Hardware single glazed double glazed

Solar Water Heating System (same as above plus pump, controllèr and check valve) single glazed double glazed - 


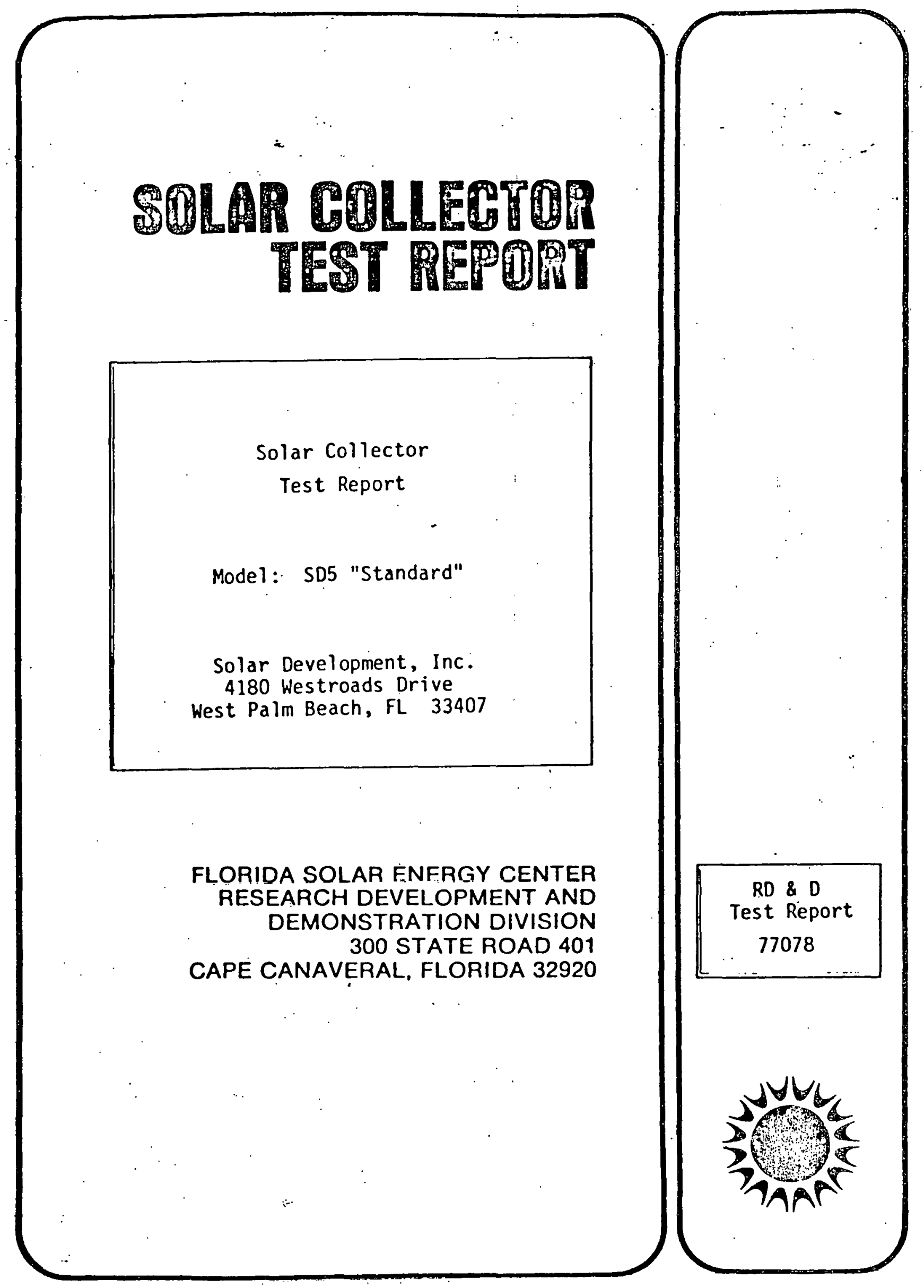




\section{SUMMARY INFORMATION SHEET}

FLORIDA SOLAR ENERGY CENTER

300 STATE ROAD 401, CAPE CANAVEAAL. FLORIDA 32920, 130517830300

FSEC \#77078

\section{MANUFACTURER}

Solar Development, Inc.

4180 Westroads Drive

West Palm Beach, FL 33407

This solar collector was tested by. the Florida Solar Energy Center (FSEC) in accordance with prescribed methods and was found to meet the minimum standards establisher by FSEC. The purpose of the tests is to verify initial performance condi. tions and quality of construction only. The resulting certification is not a guarantee of long.terin performonce or durability.

\section{DESCRIPTION}

$\begin{array}{rlr}\text { Gross Length } & 3.062 \text { meters } & 10.05 \text { feet } \\ \text { Gross Width } & 1.235 \text { meters } & 4.05 \text { feet } \\ \text { Gross Depth } & 0.093 \text { meters } & 0.31 \text { feet } \\ \text { Gross Area } & 3.782 \text { square meters } & 40.70 \text { square feet } \\ \text { Transparent Frontal Area } & 3.545 \text { square meters } & 38.16 \text { square feet } \\ \text { Volumetric Capacity } & 5.1 \text { liters } & 1.35 \text { gallons } \\ \text { Weight (empty) } & 44.4 \text { kilograms } & 97.9 \text { pounds } \\ \text { Number of Cover Plates } & \text { One } & \\ \text { Flow Pattern } & \text { Serpentine } & \end{array}$
Efficiency Equations First Order $\eta=64.1-632.6(\mathrm{Ti}-\mathrm{Ta}) / \mathrm{I}$
Second Order $\eta=61.9-427.2(T i-T a) / I-2699.1 \cdot(T i-T a) / I^{2}$
Tested per ASHRAE 93-77
Units of $\mathrm{Ti}-\mathrm{Ta} / \mathrm{I}$ are ${ }^{\mathrm{O}} \mathrm{C} / \mathrm{Watt} / \mathrm{m}^{2}$

MATERIALS

Enclosure Aluminum frame

Glazing Kalwall Sun-Lite Premium II (fiberglass reinforced plastic)

Absorber. Formed copper fin bonded to copper tube, black paint

Insulation Celotex Thermax (folyisocyanurate $2.54 \mathrm{~cm}$ )

\section{RATING}

The collector has been rated for energy output on measured performance and an assumed standard day. Total solar energy available for the standard day is 5045 watt.hour $/ \mathrm{m}^{2}\left(1600 \mathrm{BTU} / \mathrm{t}^{2}\right)$ distributed over a 10 hour period.

Output energy ratings for this collector based on the second-order efficiency curve are:

\section{Collector Temperature}

Low Temperature, $35^{\circ} \mathrm{C}\left(95^{\circ} \mathrm{F}\right)$

Intermediate Temperature, $50^{\circ} \mathrm{C}\left(122^{\circ} \mathrm{F}\right)$

High Temperature, $100^{\circ} \mathrm{C}\left(212^{\circ} \mathrm{F}\right)$

\section{Energy Output}

38,600 Kilojoules/day.

28,600 Kilojoules/day

3,200 Kilojoules/day
36,600 8TU/day

27,100 BTU/day

$3,100 \mathrm{BTU} / \mathrm{day}$ 
1. COLLECTOR DESCRIPIION.

1.1 Collector Identification

Manufacturer and Address:

Solar Development, Inc:

4180 Westroads Drive.

West Palm Beach, FL 33407

Collector Model Number:

SD5 "Standard"

\subsection{Collector Construction}

Overall Dimensions:

Length: $3.062 \mathrm{~m}$

Width: $1.235 \mathrm{~m}$

Depth: $0.093 \mathrm{~m}$

Overall Front Area: (length $\times$ width) $-3.782 \mathrm{~m}^{2}$

Height of outlet above inlet when collector tilt is $90^{\circ}: 1.045 \mathrm{~m}$ Glazing:

Material: Kalwall

Thickness: $0.064 \mathrm{~cm}(0.025$ inch)

Transmittance ${ }^{\star}: \quad 88 \%$

No: of Cover Plates: One

Transparent Frontal Dimensions:

Length: $3.007 \mathrm{~m}$

Width: $\quad 1.179 \mathrm{~m}$

Area: $\quad 3.545 \mathrm{~m}^{2}$

Absorber:

Material: Copper alloy 110

Length: $2.997 \mathrm{~m}$

Width: $1.194 \mathrm{~m}$

Area: $\quad 3.578 \mathrm{~m}^{2}$

Absorber Coating: Black paint by Cypress Coatings

Absorptivity*: Unknown

$\therefore$ Emissivity*: Unknown. 
Air Spacing Giazing to Absorber: Approx. $4.5 \mathrm{~cm}$

Insulation:

Type: Cellotex Thermex

Dimensions: $2.54 \mathrm{~cm}$

K-Factor ${ }^{\star}: 0.02$ Watts $/ \mathrm{m}^{0} \mathrm{C}\left(0.13 \mathrm{Btu} / \mathrm{hr}-\mathrm{ft}^{2}{ }^{0} \mathrm{~F} / \mathrm{in}\right)$

Heat Transfer Fluid:

Haterial: Water

Densịty: $977.81 \mathrm{~kg} / \mathrm{m}^{3}$ at $70^{\circ} \mathrm{C}$

Specific heat: $4189.6 \mathrm{~J} / \mathrm{kg}{ }^{\circ} \mathrm{C}$ at $70^{\circ} \mathrm{C}$

Collector Height: $44.4 \mathrm{~kg}$

Collector Height/Area: $\quad 11.7 \mathrm{~kg} / \mathrm{m}^{2}$

Collector Fluid Capacity: 5.1 liters

Collector Fluid Capacity/Area: 1.35 liters $/ \mathrm{m}^{2}$

Normal Operating Temperature Range: $24^{\circ} \mathrm{C}$ to $93^{\circ} \mathrm{C}$

Manufacturers Recommended Fluid Flow Rate: 2.8 liters/min (0.75 GPM)

Manufacturers Recommended Maximum Operating Pressure: 276 kilopascals (40 psig) tested to 1103 (160 psig)

Cover Plate Wind Load Maxinum: 1436 Pascals (30.psf)

*Information provided by manufacturer; not verified by FSEC. 


\section{RESULTS}

\subsection{Introduction}

Results of the thermal performance tests are presented in graphical and tabular form. The first graph shows the efficiency plot in the International System of Units (Metric units). Following this is a comparison of the collec. tor efficiency before and after exposure testing. Finally, the tabulated data ie presented. The performance graphs and the tabulated data are also presented in Section 2.6 in English units of measure.

\subsection{Explanation of Results}

The Solar Development, Inc. model SD5 "Standard" solar collector was tested for time constant and thermal performance. The time constant was found to be 1.3 minutes. A thermal performance test was conducted during the period from 12 February to 14 February 1978. An incident angle modifier test will be conducted. After these tests were completed the collector was filled with water, capped with a pressure relief valve set at $414 \mathrm{kPa}$ and placed on an exposiure rack for a period of 40 days. During this period there.were at least thirty days on with the tctal daily insolation was greater than 4730 watt-hours per square meter $\left(1500 \mathrm{Btu} / \mathrm{ft}^{2}\right)$ and at least one day on which there was a fourhour period with a minimum insolation level of 1013 watts per square meter $\left(321 \mathrm{Btu} / \mathrm{hr}-\mathrm{ft}^{2}\right)$. During the exposure test the collector rack was adjusted to keep the angle between the incoming solar radiation and a normal to the collector surface less than five degrees at solar noon. On three of the last ten days of exposure, the collector was sprayed with water to simulate rain. A second thermal performance test was conducted during the period 21 April to 25 April 1978.

The second performance test revealed a slight decrease in performance, but within the required limits. After all the tests had been completed, the collector was disassembled and inspected. The inspection revealed minor outgassing deposits around the perimeter of the inside surface of the cover plate. No other êvidence of deterioration was found. 


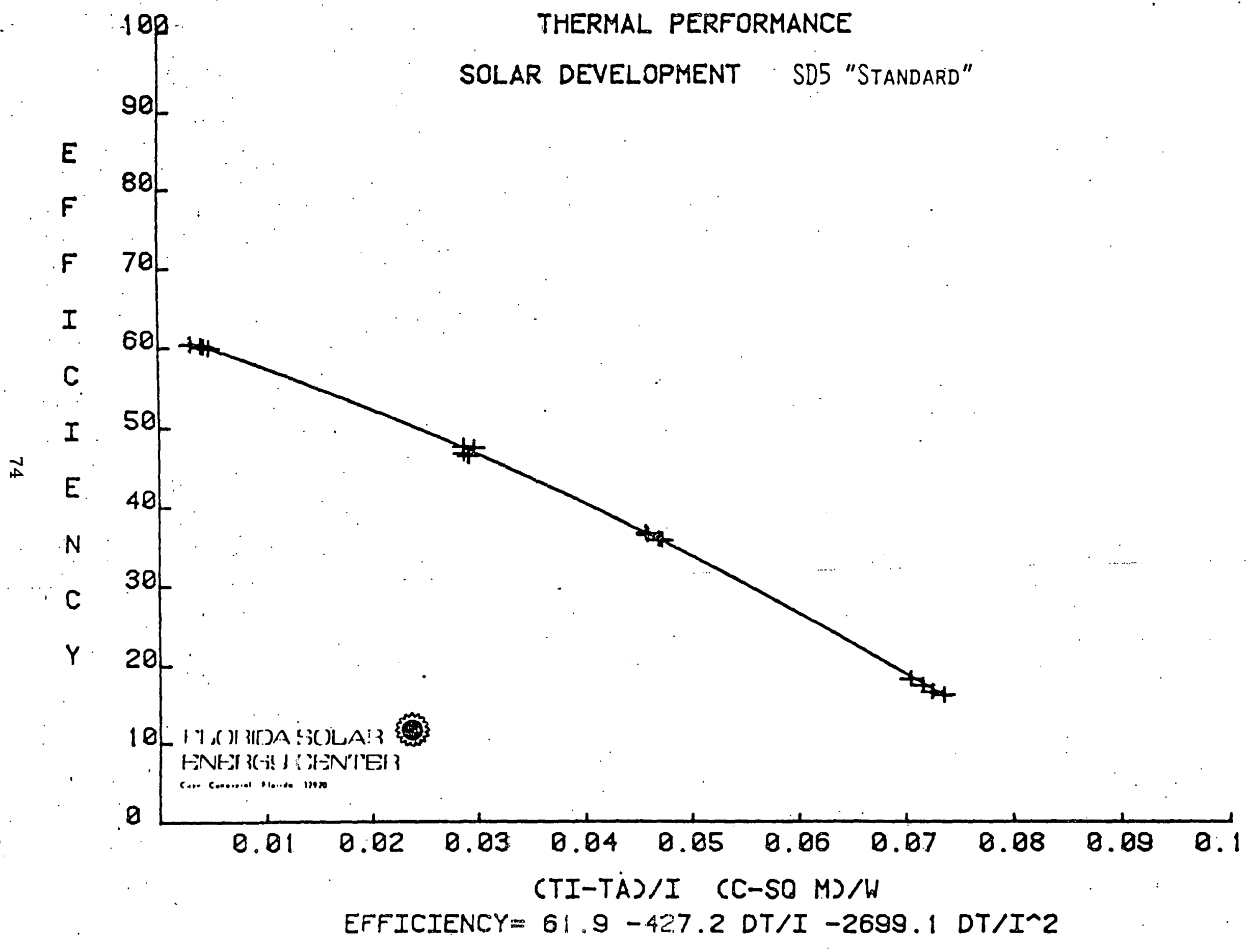




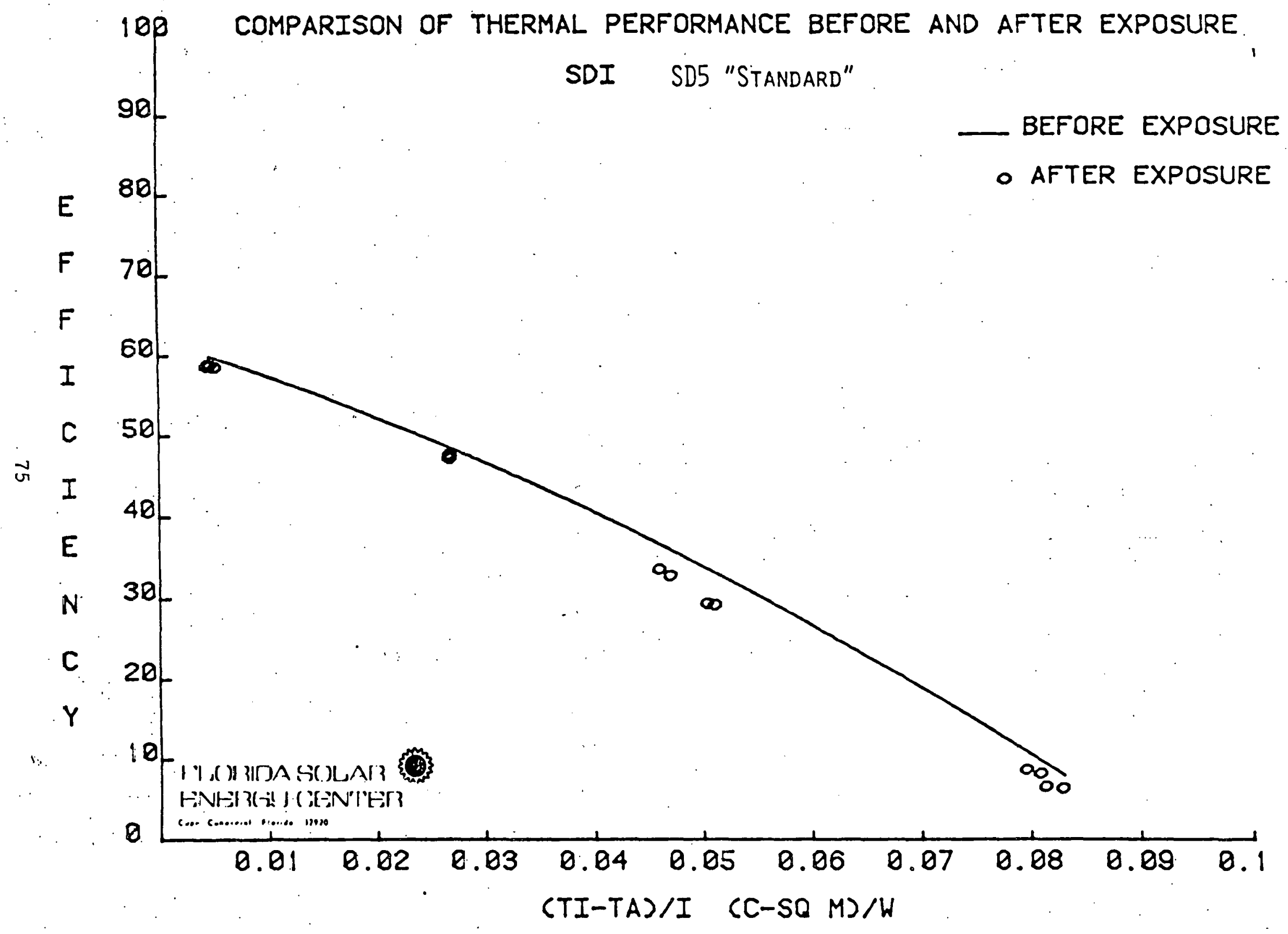




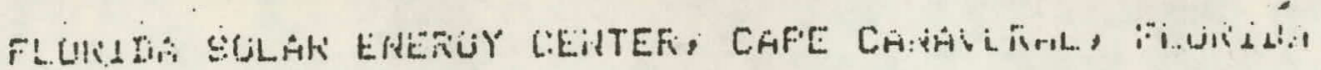

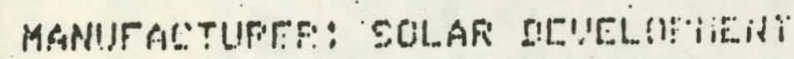

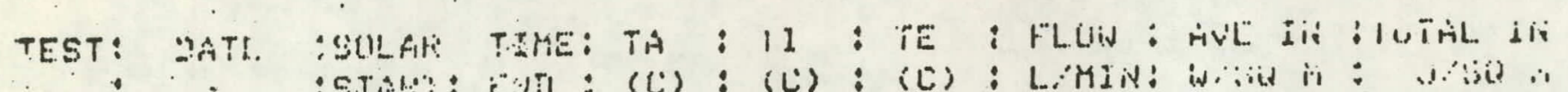

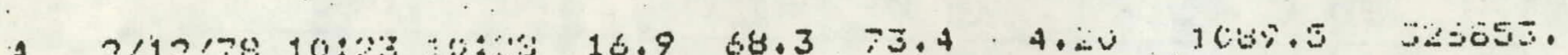

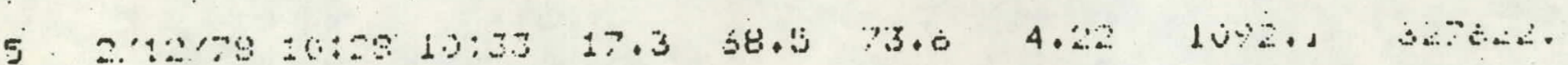

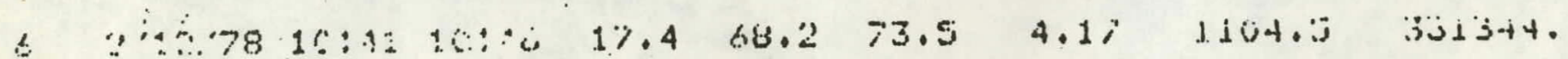

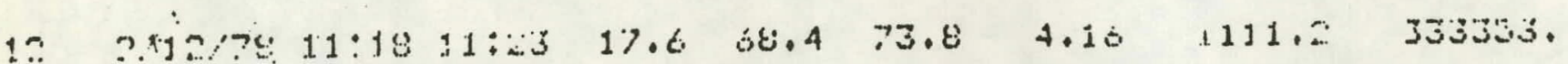

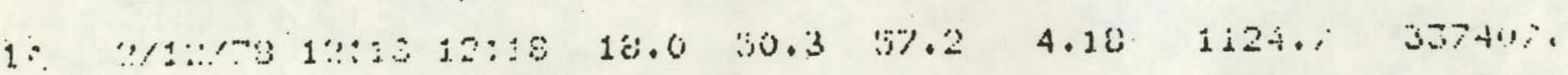

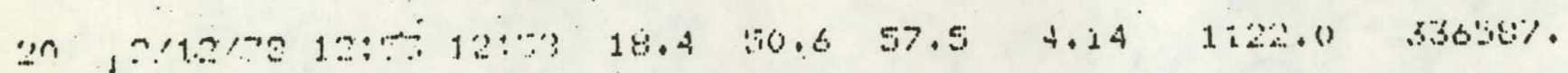

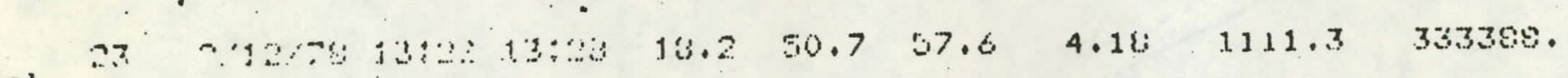

aे.

2

$\therefore$

$$
\because
$$

$$
25
$$

$$
?
$$

$$
39
$$

$$
4
$$




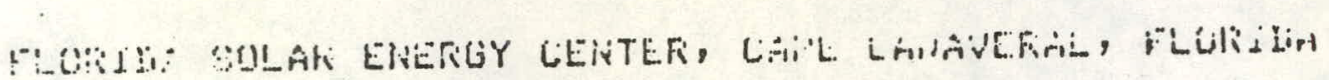

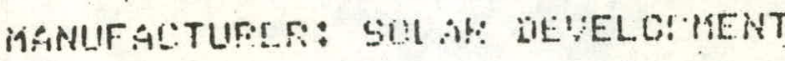

MULLL: SO5 "Standard"

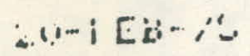

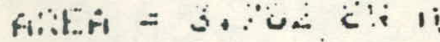

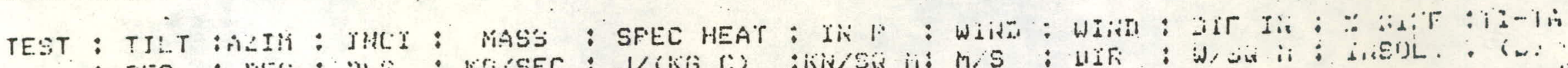

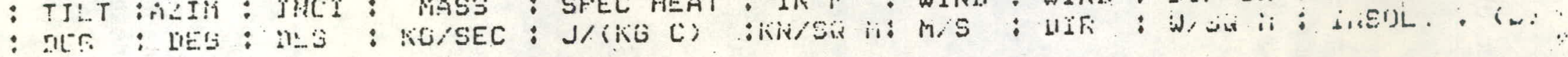

\begin{tabular}{|c|c|c|c|c|c|c|c|c|c|c|c|}
\hline 3 & x:4k & folkikx & 0. & 0.0635 & 4140.1 & 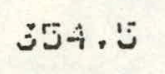 & 2.2 & $3 \div 0$ & 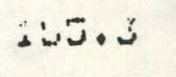 & $1+i \cdot 3$ & $5 i .4$ \\
\hline 5 & 米来 & K* & $\because$ & 9.0588 & 4190.2 & $35 \div 1$ & $\dot{B} \cdot 5$ & Su & 34.0 & 17.1 & $\sigma i \cdot \therefore$ \\
\hline 6 & $r 6+k$ & kWKkKa & $\theta$ & 0.0680 & $41 Y 0.1$ & 304.2 & $1 .+1$ & $3:$ & ن. & 14.6 & : \\
\hline $1:$ & $w: r \cdot k$ & 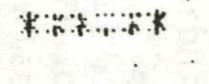 & 0. & o. 0STS & $41 \% 0.2$ & $37+\ldots$ & $1 .-1$ & IE. & Z & $i+i+3$ & 50.3 \\
\hline 14 & PXt & f*ta* & $\therefore$ & a. نsor & 4101.0 & 330.0 & I. 3 & 103. & تُ. & $i \cdot 1 . i$ & $\therefore 3$ \\
\hline$\because ?$ & $\$ \cdots+$ & $* k+k *$ & . & $0.06 \% 4$ & $4 i S 1 . \dddot{7}$ & $32 i \cdot 1$ & 1.3 & 2.0. & $i \leq L, 3$ & i. & $3 \ldots$ \\
\hline$\because 2$ & $7 \% 14$ & 11804 & $\therefore$ & $0.0<07$ & 4131.7 & $\therefore 31.4$ & $+\cdots$ & $\because y$ & $+\therefore \dot{\Delta}$ & $+9 ;$ & $\therefore \therefore$ \\
\hline$\cdots$ & +128 & $11+x+4$ & $\therefore$ & + & 4131.7 & $5=6 \cdot 4$ & $1 .:$ & i. 1 . & ILis & 15.1 & $\therefore \Delta$ \\
\hline$\because$ & $1: 18$ & $\because t+k+1$ & 0. & $(0.0385$ & $420 \%$ & $-\dot{\Delta} .+0$ & $1 . i$ & $\therefore$ & $b i \cdot \cdot i$ & Li... & $\because \ldots .>$ \\
\hline$\because 3$ & $1 \therefore 11$ & ratiox & $\because$. & $0.040 \%$ & $4.67 \cdot 0$ & $\therefore \Delta$ & $i \cdots$ & $\therefore \therefore$ & $i \omega . j$ & $i c . j$ & $\because 0$ \\
\hline 29 & 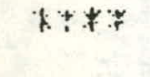 & $\neq F 1 \times 2 *$ & 0. & 0.0069 & $4: 63.2$ & ن. ن' & 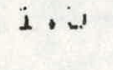 & o. & $i \Delta \alpha, \dot{C}$ & $2 \dot{4}$ & \\
\hline$\because$ & $1: 14$ & Axrotit & 6 & $0.05 \%$ & $4206 \cdot c$ & $36-4$ & $i .0$ & w. & $+\cdots+\infty$ & $i \ddot{u}$ & $: 7.2$ \\
\hline $3 c$ & artit & Fk:F:KX & $\therefore$ & 0.0056 & 4170.0 & 30. & $\therefore .6$ & 207 . & $\therefore$ Awi & $j \therefore i$ & $x^{-1}+7$ \\
\hline 40 & 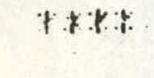 & $* * * * * * *$ & $0:$ & $0.0<86$ & 4178.1 & $351 \cdot \dot{v}$ & 3.5 & 274. & 15i i & $i-i, 4$ & ני \\
\hline 45 & TrkF & MFro* & 0. & 0.0643 & 4170.4 & 390.2 & $4 \cdot-4$ & $\because 72$. & $10 \pi .6$ & Iப. & $\therefore$ \\
\hline $4 i$ & $1.4 \%$ & Arkzo* & 0. & 0.0693 & $41 / 3.4$ & $30 \% \cdot y$ & 3,2 & $21 \%$ & 155.0 & i.ن. & 4.2 \\
\hline
\end{tabular}



HIND
Wind speed (meters/second or miles/hour)
WIND DIR
Wind direction (degrees east from north)
DIF IN
Diffuse instantaneous insolation (watts/square meter or BTU/hour-square foot)
\% DIFF
INSOL
Percent of the inconing radiation that was diffuse
TI-TA
Temperature difference between the inlet fluid tempera- ture and ambient air ( ${ }^{\circ} \mathrm{C}$ or $\left.O F\right)$

Notes:

1. The test number is simply a number assigned for use by FSEC

2. Stars indicate that no data was taken on the indicated paraneter during that test.

3. The data: presented in the test report best represent the performance of the collector during testing. The actual data points were chosen to be at the temperatures recomended by ASHRAE. 


\subsection{Results of Static Tests.}

\subsubsection{Pressure Test}

Date of Test: 10 December 1977

Static Test Pressure:. 1103 kilopascals (160 psig)

Duration of Test: 15 minutes

\subsubsection{Pressure Drop Test}

Datc of Test: 23 April 1978

Air Temperature: $\quad 25.6^{\circ} \mathrm{C}\left(78.1^{\circ} \mathrm{F}\right)$

Inlet Temperature: $\quad 27.1^{\circ} \mathrm{C}\left(80.7^{\circ} \mathrm{F}\right)$

Flow Rate: $\quad 4.24 \mathrm{~L} / \mathrm{min}(1.12 \mathrm{GPM})$

Inlet Pressure: $\quad 142.6 \mathrm{kPa}$ (20.7 psig)

Pressure Drop: $8.00 \mathrm{kPa}$ (1.16 psi)

\subsubsection{Exposure Test}

Start Date: 25 February 1978

Completion Date: 6 April 1978

110. of Days of Exposure: 40

No. of Days of Exposure when insolation exceeded 4730 watts $/ \mathrm{m}^{2}\left(1500 \mathrm{BTU} / \mathrm{ft}^{2}\right)$ : $\quad 30$

Pressure Relief Setting: $414 \mathrm{kPa}$ (60 psig)

Spray Tests:

$\begin{array}{llll}\text { Dates: } & 30 \text { March } & 02 \mathrm{April} & 03 \mathrm{April} 1978 \\ \text { Insolation: } & 946 \text { Watts } / \mathrm{m}^{2} & 1060 \mathrm{Watts} / \mathrm{m}^{2} & 996 \mathrm{Watts} / \mathrm{m}^{2} \\ & \left(300 \mathrm{Btu} / \mathrm{hr}-\mathrm{ft}^{2}\right) & \left(336 \mathrm{Btu} / \mathrm{hr}-\mathrm{ft}^{2}\right) & \left(316 \mathrm{Btu} / \mathrm{hr}-\mathrm{ft}^{2}\right)\end{array}$

\subsubsection{Inspection Results:}

Cover Plate: a minor amount of outgassing deposit was detected around the perimeter of the inside surface of the cover plate. Absorber Plate: No evidence of deterioration Absorptive Coating: No evidence of deterioration Collector Enclosure: No evidence of deterioration Insulation: No evidence of deterioration Gaskets, Caulking \& Sealants: No evidence of deterioration 


\subsection{Computer Printout Key}

TEST

DATE

SOLAR TIME

TA

TI

TE

FLOW

AVE IN

TOTAL IN

DEL T

EFFIC

$(T I-T A) / I$

TILT

AZIM

INCI

MASS

SPEC HEAT

IN $\mathrm{P}$
Number assigned to the data for a particular test

Date on which the test was performed

Solar time at the start and finish of the test

Ambient air temperature $\left({ }^{\circ} \mathrm{C}\right.$ or $\left.{ }^{\circ} \mathrm{F}\right)$

Temperature of the transfer fluid at the collector inlet $\left({ }^{\circ} \mathrm{C}\right.$ or $\left.{ }^{\circ} \mathrm{F}\right)$

Temperature of the transfer fluid at the collector exit $\left({ }^{\circ} \mathrm{C}\right.$ or of $)$

Volumetric flow rate of the transfer fluid (liters/minute or gallons/minute)

Average instantaneous insolation (watts/square meter or BTU/hour-square foot)

Total (integrated) insolation in the plane of the collector during the test period (joules/square meter or BTU/square foot)

Total (integrated) temperature rise across the collector during the test period (degree centrigrade minutes or degree fahrenheit minutes)

Calculated collector efficiency for the test period (percent)

Value calculated for the abcissa of the efficiency graph $I$ = average instantineous insolation. $\quad\left({ }^{\circ} \mathrm{C}\right.$ - square meter $/$ watt or ${ }^{\circ} F$ - hour - square foot/BTU)

Angle which the collector was tilted from the horizontal (degrees)

Collector azimuth angle (degrees from due south; east positive)

Angle between the incoming radiation and a normal to the collector surface (degrces)

Mass flow rate of the transfer fluid (kilograms/second or pounds mass/minute)

Specific heat of the transfer fluid (joules/kilogram $-{ }^{\circ} \mathrm{C}$ or BT.U/pound mass - ${ }^{\circ} \mathrm{F}$ )

Gage pressure at the collector inlet (kiloliewtons/square meter or pounds/square inch) 


\subsection{Explanation of Efficiency Curve}

The test data is presented in tabular form and as an efficiency curve. The efficiency curve is based on the following equation:

$$
n=F_{R}(\tau \alpha)_{e}-F_{R} U_{L} \frac{\left(T_{i}-T_{a}\right)}{I}
$$

where:

$$
\begin{aligned}
n & =\text { collector efficiency } \\
F_{R} & =\text { heat removal factor } \\
(\tau a)_{e} & =\text { effective transmissivity-absorptivity product } \\
U_{L} & =\text { over-all heat loss coefficient } \\
T_{i} & =\text { transfer fluid temperature at the collector inlet } \\
T_{\mathbf{a}} & =\text { ambient air temperature } \\
I & =\text { instantaneous level of solar radiation }
\end{aligned}
$$

The standard form of the equation of a straight line is:

$$
Y=b+m x
$$

where:

$$
\begin{aligned}
& b=Y \text { axis intercept } \\
& m=\text { slope }
\end{aligned}
$$

From these two equations it can be seen that a straight line should result if a plot nf efficiency versus the quantity $\frac{T_{i}-T_{a}}{l}$ is made and if the slope and intercept functions can be assumed constant. It then becomes apparent that the slope of the line is a function of the over-all heat loss coefficient and the $Y$ axis intercept is a function of the transmissivity of the cover plate(s) and the absorptivity of the absorber plate(s). In reality, however, $U_{L}$ is not constant under the test conditions since it varies with. the temperature of the collector and ambient weather conditions. Therefore a second order curve is used to describe the themal performance of the collector. That is:

$$
y=c+b x+a x^{2}
$$

The intercept is still related to $(\tau \dot{\alpha})_{e}$ and the slope at any point on the curve is proportional to the heat luss rate for that value of $\frac{T_{i}-T_{a}}{I}$. 


\subsection{Performance Test Results, English Units}

Following is a repetition of the thermal performance curve. Although identical to the previous graph (see Sec. 2.1) in content, this graph and computer printout is presented in English units. 
The efficiency curve does not give absolute values for the overall heat loss coefficient and $(\tau a)_{e}$ since both are multiplied by the factor $F_{R}$. However, the plot does indicate relative values for these two quantities that can be used for comparing collectors. Determination of the absolute values of $(\tau \alpha)_{e}$ and $U_{L}$ would require additional measurements beyond the tests performed.

The $x$ quantity, $\frac{\dot{T}_{i}-\dot{T}_{a}}{I}$, can be determined from measurements made during testing. The collector efficiency can be calculated from the following equation:

$$
n=\frac{\dot{m} C_{P} \int \Delta T d t}{A \int I d t}
$$

where:

$\dot{m}=$ mass flow rate of the transfer fluid

$C_{p}=$ specific heat of the transfer fluid

$s \Delta T d t=$ integrated (total) temperature rise across the collector

$A=$ gross frontal area

= integrated (total) solar radiation received by the collector sidt during the test.

The data is collected during a series of test runs. Each data point, represented as a plus sign on the efficiency plat, is the result of a test run, the exact length of the run being determined by the collector time constant. The line drawn on the plot is a second order least squares curve fit of the data points. 


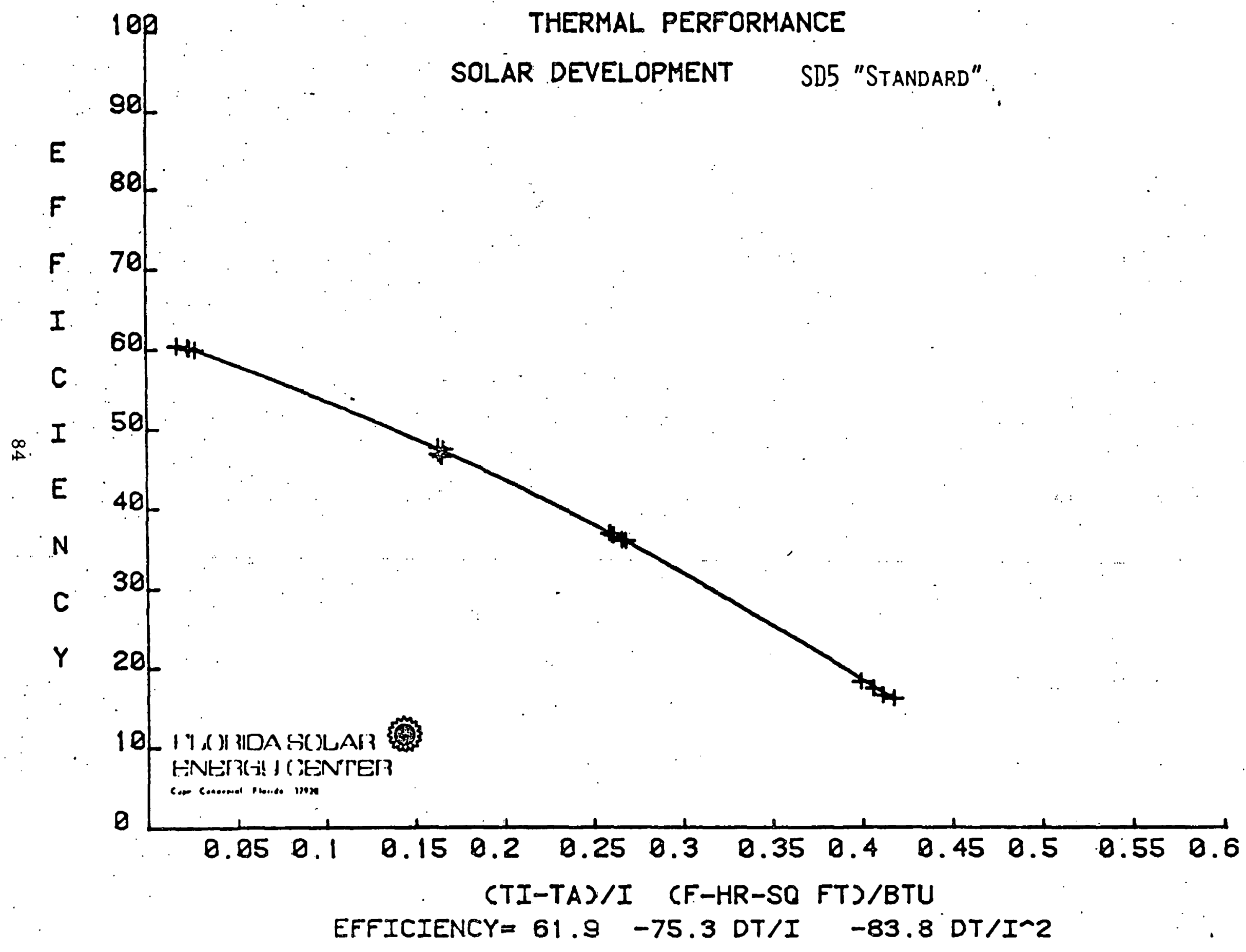




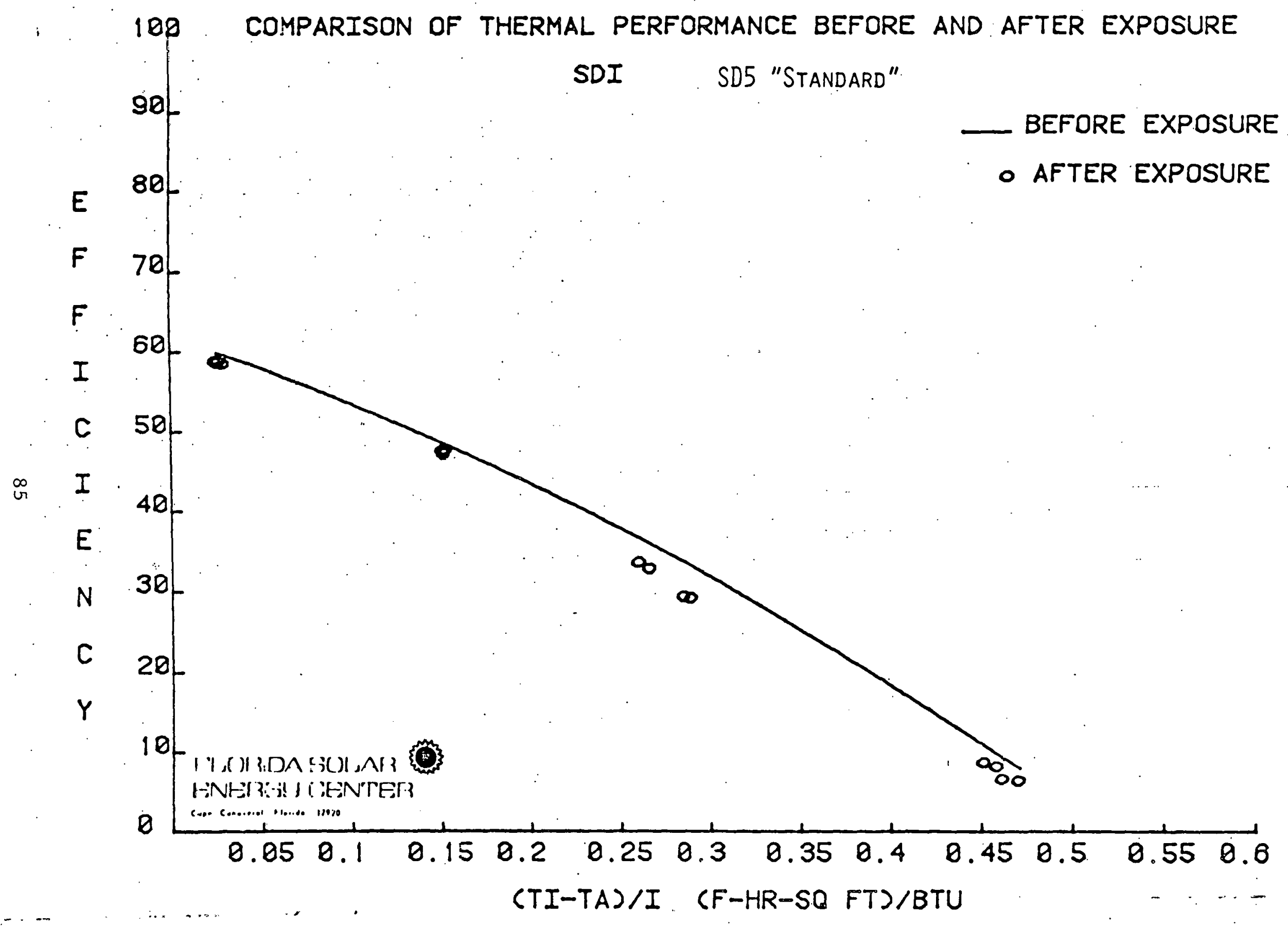




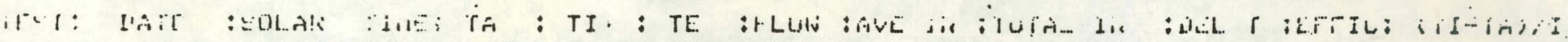

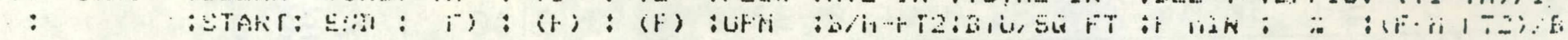

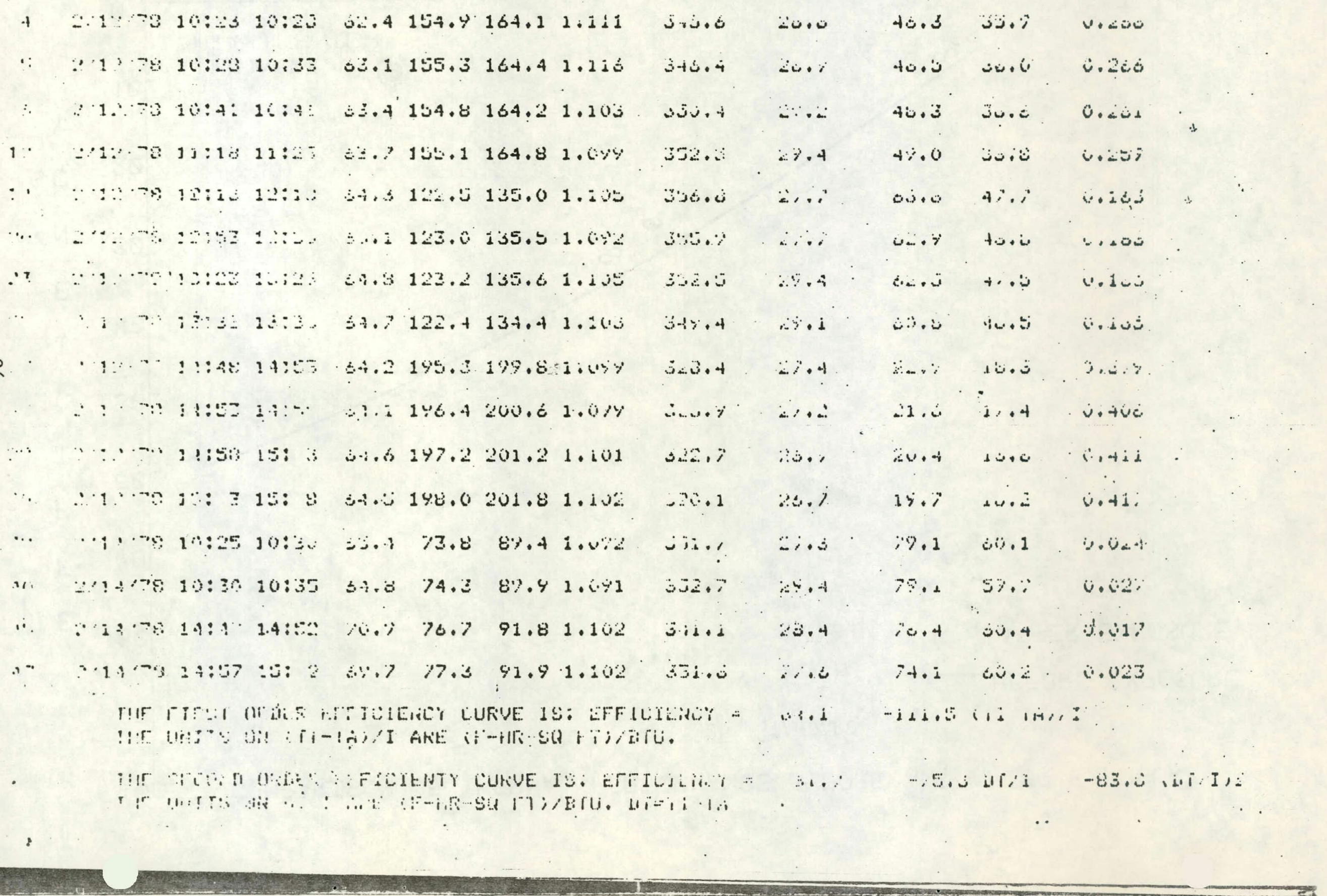




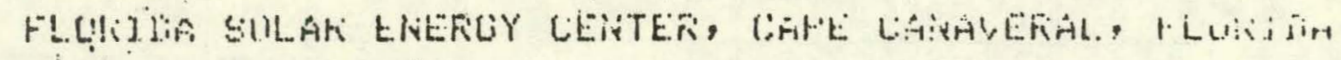
$\therefore$ 1 2 i. $7: 3$ MANUFGCTUFEF: SOLAK LEVE: CFHETT

\section{MOTELL: SDS "Standard"}

\begin{tabular}{|c|c|c|c|c|c|c|c|c|c|c|c|}
\hline TEST: & $\begin{array}{l}\text { TIL:T: } \\
\text { IIt:G: }\end{array}$ & $\begin{array}{l}: A \because 111: \\
: \text { LEG : }\end{array}$ & $\begin{array}{l}\text { Liid: } \\
\text { Li: : }\end{array}$ & : RASS: & 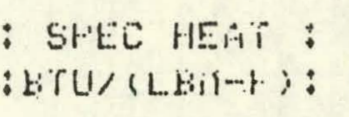 & $\begin{array}{l}\operatorname{lii} r^{\circ}: \\
r i \mathrm{i}:\end{array}$ & $\begin{array}{l}\text { Wilidi: } \\
11: 4:\end{array}$ & $\begin{array}{l}\text { wirit : } \\
\text { wdli : }\end{array}$ & 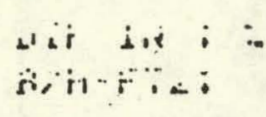 & $\begin{array}{l}=\text { irr } \\
\text { il.uili }\end{array}$ & $\begin{array}{l}1+\cdots \\
. \quad \cdots\end{array}$ \\
\hline 4 & $* * k * *$ & $*: * * * \pi$ & $\therefore 0$ & 9.06 & 1.061 & $=1.4$ & $\because 7$ & 326 & $8 ; 0$ & 24.3 & $\therefore \therefore$ \\
\hline s. & 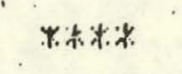 & $x: 4 * x$ & $\because, 6$ & 4.10 & 1.001 & 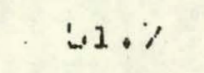 & $\therefore \dot{ }$ & $\therefore$ 哽。 & 4s. & $i \cdot i \cdot i$ & $\therefore i$ \\
\hline 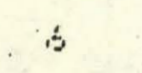 & 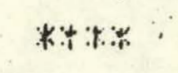 & ***: & $\therefore, 6$ & 8.49 & $1 \cdot \cos 1$ & $3 \therefore+y$ & $\therefore$ & $\therefore \Delta$. & $4 \cdot .1$ & $1+.6$ & $\because \mathrm{i} \cdot-\mathrm{i}$ \\
\hline 12 & स\%* & xk+* & 0.0 & 8.97 & 1.0101 & 54.3 & $\exists \cdot 1$ & 1usi. & $5 i \div, i$ & 12.3 & $\because \ldots+$ \\
\hline 14 & r.k:k & raxk & 6,9 & 9.04 & 0.499 & $-4 v \cdot v$ & $\therefore \ldots$ & 103. & 50.3 & $i-1, i$ & $\therefore \therefore$ \\
\hline$\therefore 0$ & $x: 1 \%$ & 楼本 & 0.0 & 8.97 & $0.4 \%$ & $-1 \therefore 0$ & $\therefore \because$ & iict. & 01.3 & 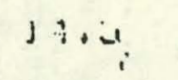 & $\therefore \ldots$ \\
\hline 23 & $x+1+x$ & $1 x+1$ & 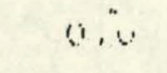 & $5.0 \%$ & $0.99 \%$ & $4 i+1$ & $\therefore+\infty$ & $\therefore$ & $\therefore \ldots$ & $\because i$ & i. . . \\
\hline ن!: & 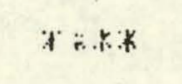 & 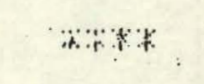 & ij. i & $y .0 \%$ & 0.949 & $4 \therefore$ & 3.6 & $\therefore$ & $\therefore ;$ & $1 \approx \ldots$ & $-\quad \cdots$ \\
\hline 27 & i. AK & HA & $\therefore, \cdots$ & 8.84 & $1: 005$ & $\therefore \ldots+5$ & $3 \ldots$ & $\because \therefore$ & $4 \therefore$ & 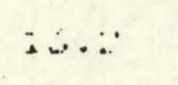 & $1 \ldots$ \\
\hline 26 & 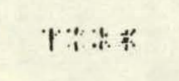 & Ant & $a, \cdots$ & 8.84 & 1. & 3.20 & $\therefore$ & $\therefore 2$. & $\therefore \ldots .+4$ & I... I & i $\therefore . .1$ \\
\hline$\because 4$ & $F x+\%$ & $x+x+7$ & $(\because)$ & 8.85 & - 1 . 1001 & 3.3 .0 & 3.4 & \% & $\therefore 1.0$ & $1 \ldots$. & $\ldots \ldots$ \\
\hline 30 & 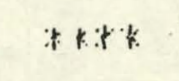 & $\therefore$ *k* & $\because 0$ & 8.86 & i. isis & 23.1 & $\therefore 7$ & 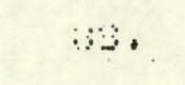 & $\therefore \ldots$ & $\therefore \therefore$ & 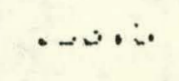 \\
\hline 3 & $y+k$ & rata & $\therefore, 6$ & 3.08 & 0.958 & $30, y$ & $\because, \infty$ & $2 \omega i$ & 50.7 & $1+00$ & $\therefore+$ \\
\hline 40 & Axt.t. & 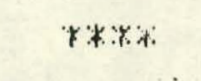 & $\therefore, c$ & 9.08 & 0.598 & $50+\%$ & $\therefore 8$ & $\therefore \rightarrow$ & inei & $1+\ldots .1$ & $\because .3$ \\
\hline 4 & 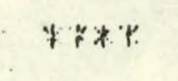 & 米米来 & 0.0 & $9 \cdot 16$ & 0.5180 & $\therefore 6+0$ & 9.8 & 27. & 63.2 & w: & $\therefore z$ \\
\hline $4 \%$ & $7 \%$ & K*kx & 0.0 & 9.16 & 0.940 & 500 & $\because .2$ & $2 \%$ & $=2.3$ & is.s & $\therefore=$ \\
\hline
\end{tabular}


CARTRIDGE TYPE IN-LINE PUMPS ․․

EFFECTIVE: APRIL 1, 1974 NOTE: TACO Submittal Data cheet SUPERSEDES: NEW
SD $300 \cdot 1 \cdot 5$ SD $300 \cdot-8$

SD 300-1.9 SD 300 .

are OBSOLETE and are NO LONGER VALID.

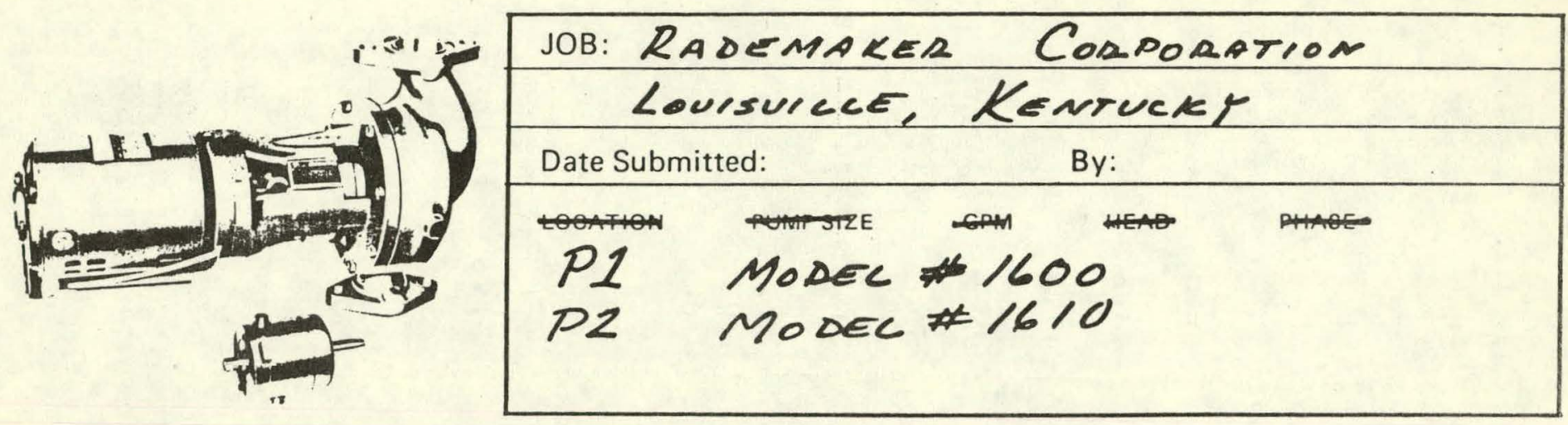

\section{SPECIFICATIONS:}

\section{MOTORS}

1750 RPM, Three Phase 200V or 230/460V 60C Sleeve Bearing Motors. Also available in Single Phase with overload protection except $3 \mathrm{HP}$. BODY

Cast Iron with flanged in-line connections.

Companion flanges are included

IMPELLER

Cast Bronze, Closed, Dynamically Balanced.

DRIVE COUPLING

Non-Metallic / Vibration Dampening

SHAFT

Stainless Steel with Cupro-Nickel Sleeve.

FRAME

Sleeve Bearing,Disc Type, Oil lubricated. REMOVABLE BEARING CARTRIDGE FITS ALL MODELS. Dip Stick to measure oil level. MECHANICAL SEAL

Standard $-250^{\circ} \mathrm{F}$ Operating Temp.

WORKING PRESSURE

$175 \mathrm{PSI} . .$. in accordance with ASA B16.1

NOTE: Flanges are tapped for gauges

\section{SIZES \& DIMENSIONS:}

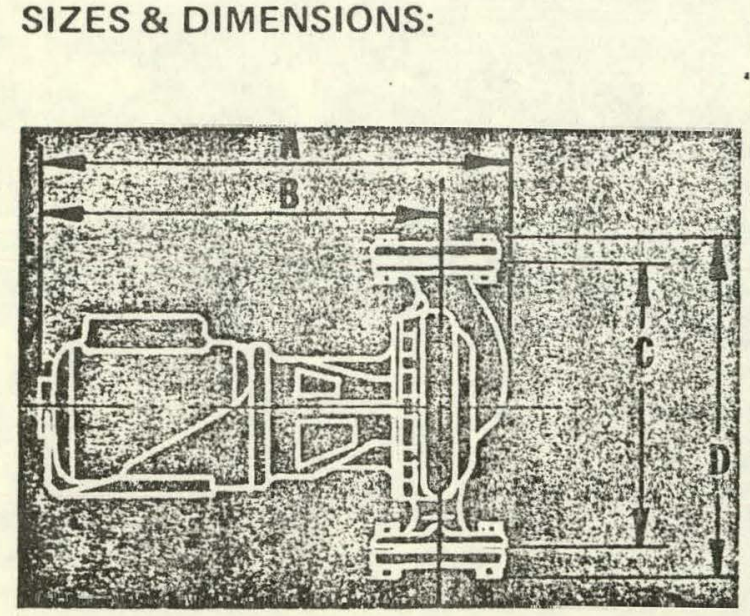

\begin{tabular}{|c|c|c|c|c|c|c|c|c|}
\hline \multirow{2}{*}{$\begin{array}{l}\text { MODEL } \\
\text { NO. }\end{array}$} & \multirow{2}{*}{$\begin{array}{l}\text { Flg. } \\
\text { Size }\end{array}$} & \multicolumn{3}{|c|}{ MOTOR DATA } & \multicolumn{4}{|c|}{ DIMENSIONS } \\
\hline & & HP & $60 \mathrm{~Hz} 1 \mathrm{Ph}$. & $60 \mathrm{~Hz} 3 \mathrm{Ph}$. & A & B & c & D \\
\hline 1600 & \multirow{4}{*}{$1 \frac{1}{2}$} & $1 / 4$ & $115 \mathrm{~V}$ & \multirow{2}{*}{ NOT AVAILABLE } & 19 & $16 \%$ & $10 \%$ & $127 / 8$ \\
\hline 1610 & & $1 / 3$ & $115 \mathrm{~V}$ & & 19 & $16 \%$ & $10 \%$ & $127 / 8$ \\
\hline 1612 & & $1 / 2$ & \multirow{8}{*}{$115 / 230$} & \multirow{8}{*}{200 or $230 / 460$} & 21 & $18 \frac{1}{2}$ & $13 \frac{1}{2}$ & $161 / 8$ \\
\hline 1614 & & $3 / 4$ & & & $21 \frac{1}{2}$ & 19 & $13 \frac{1}{2}$ & $16 \frac{18}{8}$ \\
\hline 1616 & \multirow{6}{*}{12} & 1 & & & 22 & 19 & $14 \frac{1}{2}$ & $173 / 8$ \\
\hline 1630 & & $1 / 2$ & & & $21 \frac{1}{2}$ & 18 & $13 \frac{1}{2}$ & $161 / 8$ \\
\hline 1632 & & $3 / 4$ & & & 22 & $181 / 2$ & $13 \frac{1}{2}$ & $161 / 8$ \\
\hline 1634 & & 1 & & & $22 \frac{1}{2}$ & 19 & $13 \frac{1}{2}$ & $16^{\mathrm{lh}}$ \\
\hline 1636 & & $1 \frac{1}{2}$ & & & $24 \frac{1}{2}$ & 21 & $16^{1} / 2$ & $19 \%$ \\
\hline 1638 & & 2 & & & $26 \% / 2$ & 23 & $16 \frac{1 / 2}{2}$ & $19 \frac{1}{2}$ \\
\hline
\end{tabular}

Taco Heaters of Canada, Ltd. 3090 Lenworth Drive Mississauga, Ontario

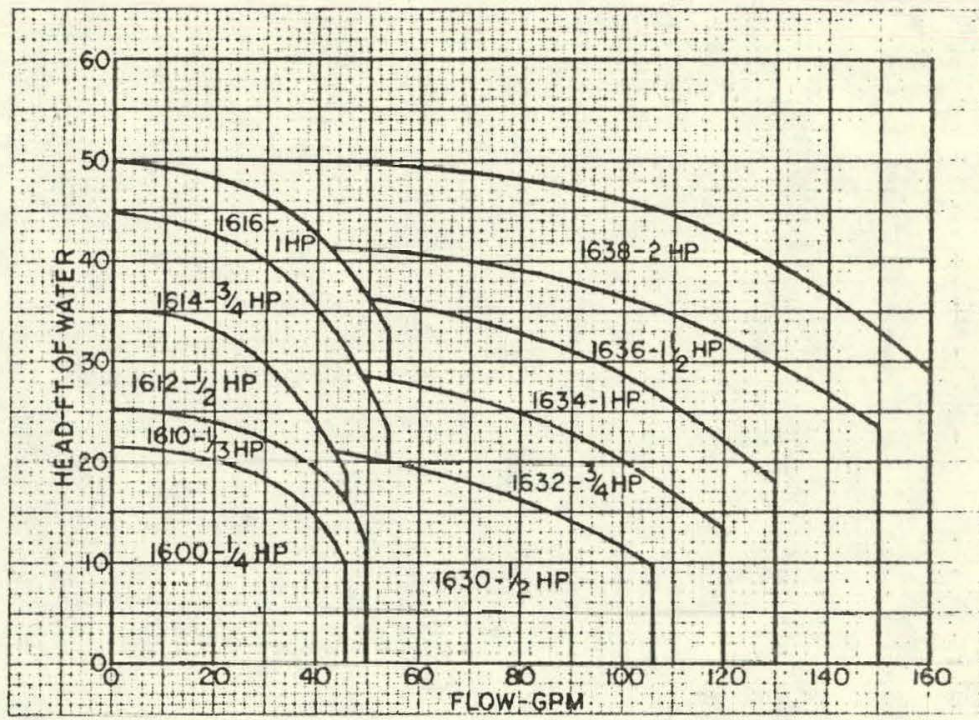

Taco, Inc. 1160 Cranston Street, Cranston, Rhode Island 02920 U.S.A. printed in U.S.A. 


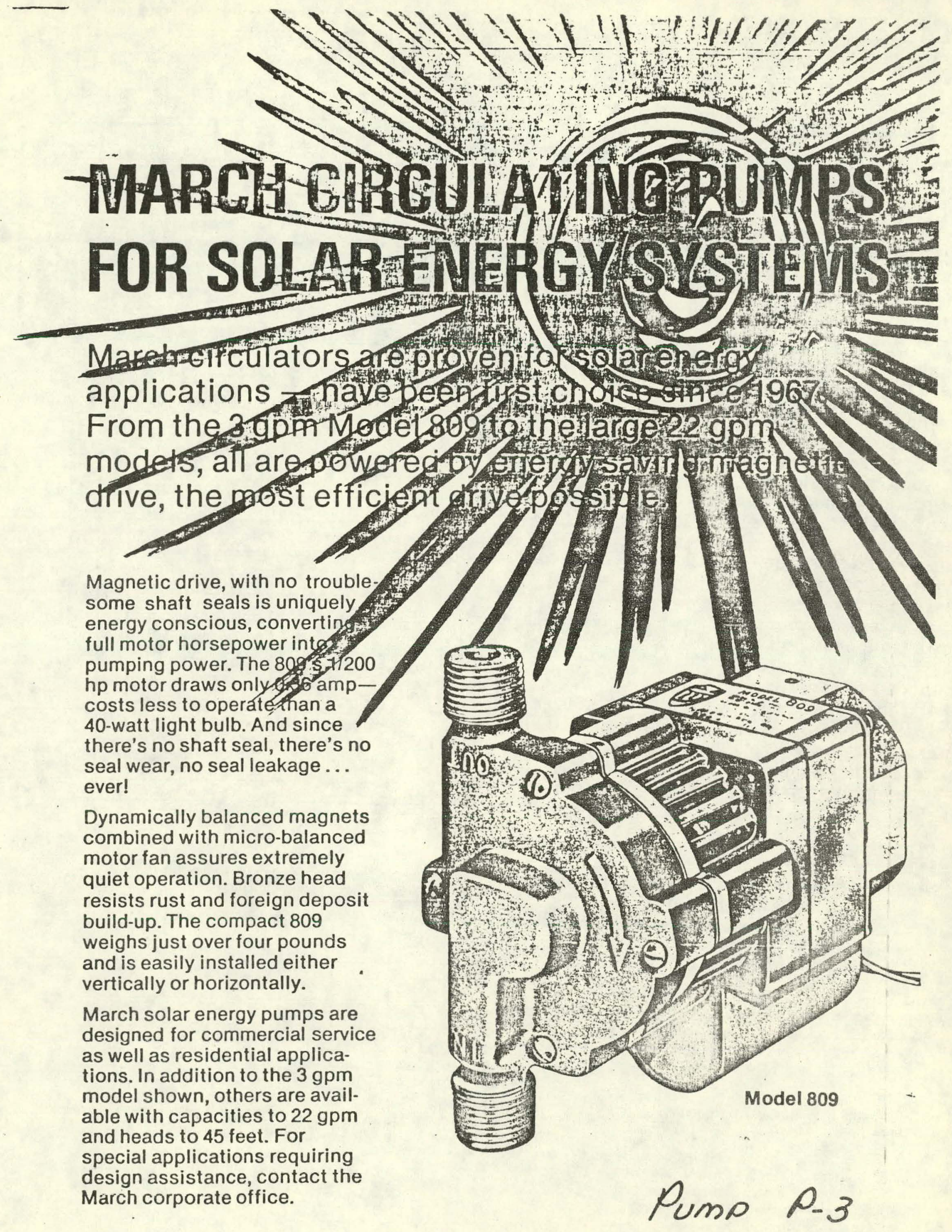




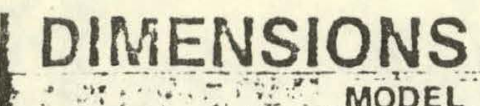

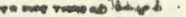
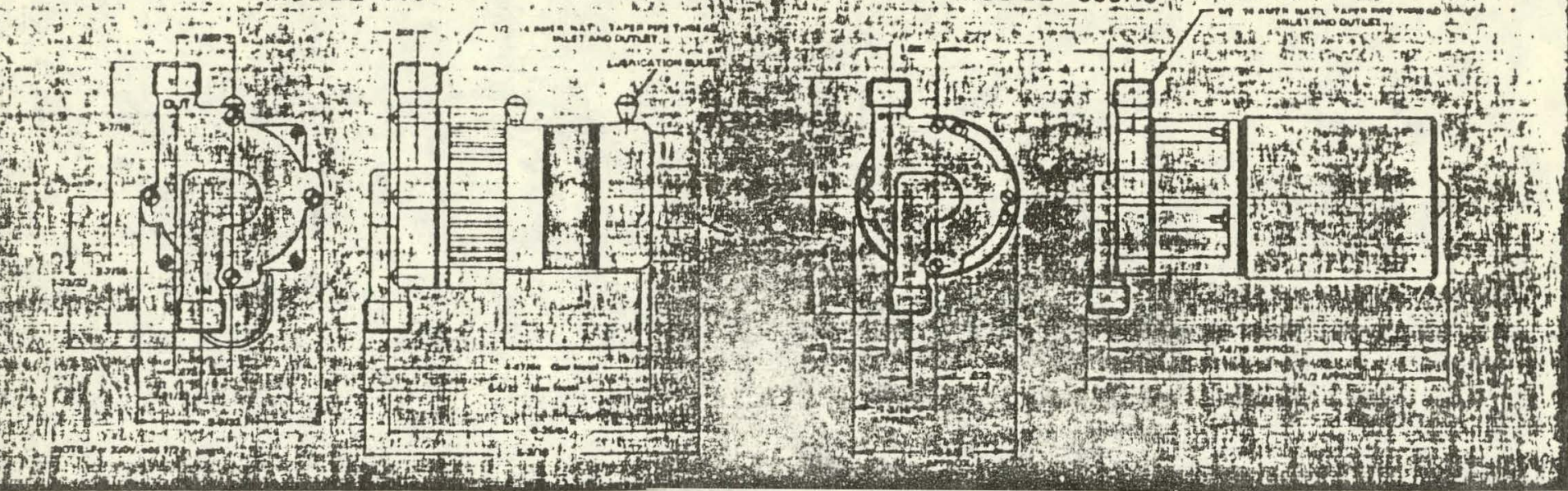

\section{MAGNETIC DRIVE}

March's proven magnetic drive eliminates the troublesome, old-fashioned shaft seal. There can be no seal wear, power-robbing friction or leakage thru the seal. Impeller and drive magnets are permanent ceramic type. They prevent slippage and insure that full motor horsepower is converted into pumping power. Energy requirements are lowered as

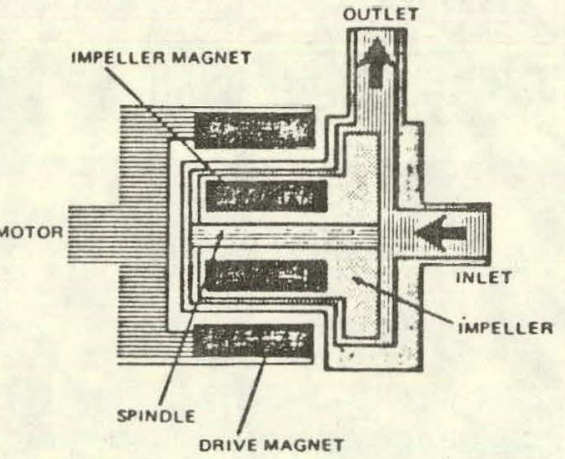
all the energy produced by the motor is utilized, especially important in solar systems. March seal-less drive also provides for faster, easier motor service, as the motor can be removed without draining, refilling and reheating the system.

\section{PERFORMANCE}

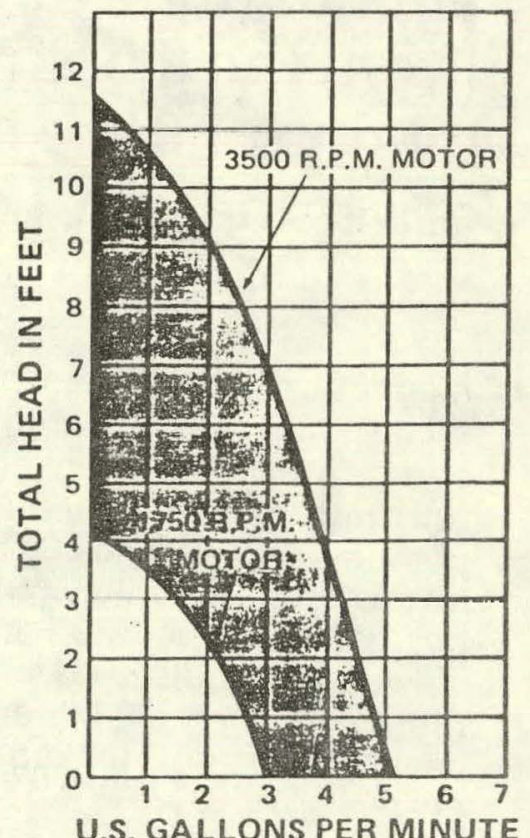

\section{SPECIFICATIONS}

\begin{tabular}{|c|c|c|c|c|c|c|c|c|c|c|c|c|}
\hline \multirow{2}{*}{ 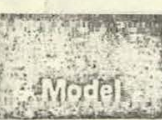 } & \multirow{2}{*}{$\begin{array}{l}\max \\
\text { flom }\end{array}$} & \multirow{2}{*}{$\begin{array}{l}\text { Maxi } \\
\text { Head }\end{array}$} & \multirow{2}{*}{$\frac{\max }{451}$} & \multirow{2}{*}{ Dinet \& Outlet } & \multicolumn{7}{|c|}{ Motor } & \multirow{2}{*}{$\begin{array}{l}\text { Pack } \\
\text { twh }\end{array}$} \\
\hline & & & & & $4 \mathrm{HP}$ & RPM & Volits & Cycles & Phase & Watts & Amps. & \\
\hline $\begin{array}{l}809 \\
809 \mathrm{DF} \\
809 \mathrm{DF}-24\end{array}$ & $3 \mathrm{gpm}$ & 4.1 & 1.8 & $1 / 2 "$ MPT & $1 / 200$ & 1750 & $\begin{array}{c}115 \text { or } \\
230 \\
24\end{array}$ & 60 & Single & 24 & $\begin{array}{l}.36 \text { or } \\
.26 \\
.\end{array}$ & $4.5 \mathrm{lbs}$. \\
\hline $809 \mathrm{HS}$ & $5.3 \mathrm{gpm}$ & 11.6 & 5.0 & $1 / 2 " M P T$ & $1 / 25$ & 3500 & $\begin{array}{c}115 \\
\text { or } \\
230\end{array}$ & 60 & Single & 80 & $\begin{array}{l}1.2 \\
\text { or } \\
.6\end{array}$ & $8.0 \mathrm{lbs}$. \\
\hline
\end{tabular}

\section{Model 809}

The original solar energy circulating pump.

Model 809 HS

3500 RPM model for almost twice the capacity and nearly three times the head.
Model 809 DF

Dual fans for quiet, cool operation in closed-in or hot environments.

Model 809 DF-24

As above except 24 volt version.

Higher capacity models are also available. Contact March or nearest March distributor for details. 

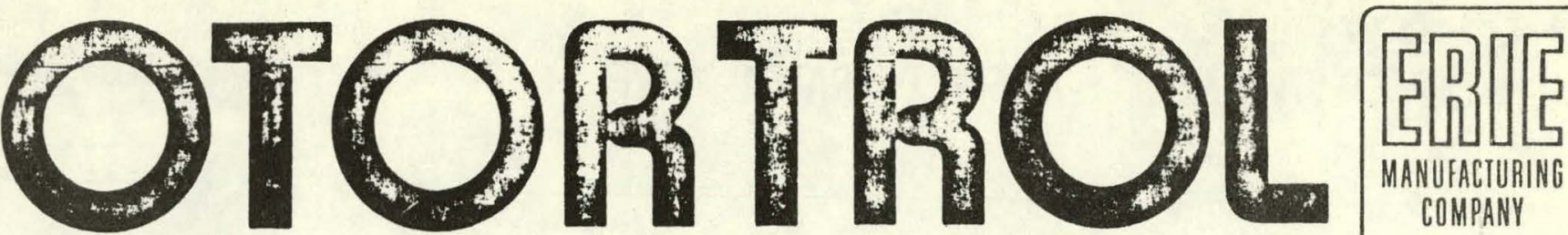

MANUFACTURING COMPANY

HI FLOW

HI PERFORMANCE

MOTOR OPERATED

VALVES

FOR SUPER

CHILLED MATER.

HOT WATER

AND STEAM

APPLICATIONS

- large fan colls

- gas absopption chiller systems

- convection systems

- valence systems

- RADIANT SYSTEMS

- INDUCTION SYSTEMS

\section{CHECK THESE}

IMPORTANT FEATURES:

- forged baAss bodr

- INCREAsed capacity

- High differential capacity

- $100 \%$ SHUTOFF

- no solenaids

- motor DaIVEN to the open and closed position

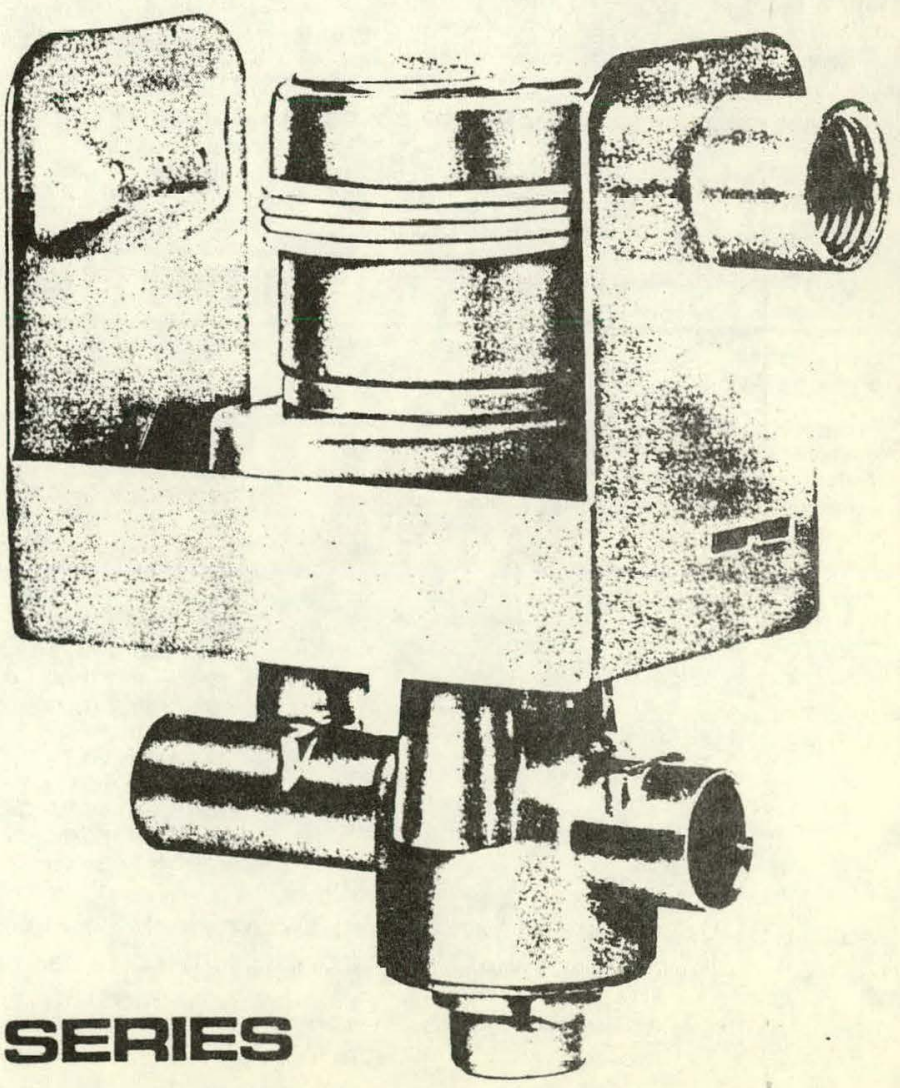




\section{HIGH CAPACITY REVERSIBLE MOTOR OPERATED VALVES}

\begin{tabular}{|c|c|c|c|c|c|c|}
\hline \multirow{2}{*}{$\begin{array}{l}\text { Valve } \\
\text { Series }\end{array}$} & \multirow{2}{*}{$\begin{array}{l}\text { Pipe Connections and Diameters } \\
\text { (Threaded Valve Connections are NPT } \\
\text { Conduit Conneclor is } 1 / 2 \text { " STD) }\end{array}$} & \multirow[b]{2}{*}{ Model } & \multicolumn{2}{|c|}{ Valve Ports - Size } & \multirow{2}{*}{$\begin{array}{l}\text { Service } \\
\text { Port Cv } \\
\text { Factor } \\
\text { (Based on } \\
\text { U.S. gal.) }\end{array}$} & \multirow{2}{*}{$\begin{array}{l}\text { Optional } \\
\text { Equipme } \\
\text { (See } \\
\text { Below) }\end{array}$} \\
\hline & & & End $B$ & End A & & \\
\hline \multicolumn{7}{|c|}{ Fan coll valves for chilled water and not water app'ications } \\
\hline $\begin{array}{l}552 \mathrm{BR} 3302 \\
552 \mathrm{BR} 3303\end{array}$ & $\begin{array}{l}\text { 1" Pipe Thread Female } \\
\text { 1" Pipe Thread Female }\end{array}$ & $\begin{array}{l}\text { 2-way } \\
\text { 3-way }\end{array}$ & $\begin{array}{l}.6 " \\
.65^{\prime \prime}\end{array}$ & $.5^{\prime \prime}$ & $\begin{array}{l}9.2 \\
9 .\end{array}$ & $\begin{array}{l}2,3,6,8 \\
2,3,6,8\end{array}$ \\
\hline \multicolumn{7}{|c|}{ Steam and hot water valves } \\
\hline $\begin{array}{l}552 \mathrm{BR} 3402 \\
552 \mathrm{BR} 3403\end{array}$ & $\begin{array}{l}\text { 1" Pipe Thread Female } \\
\text { 1" Pipe Thread Female }\end{array}$ & $\begin{array}{l}\text { 2-way } \\
\text { 3-way }\end{array}$ & $\begin{array}{l}.6^{\prime \prime} \\
.65^{\prime \prime}\end{array}$ & $.5^{\prime \prime}$ & $\begin{array}{l}9.2 \\
9 .\end{array}$ & $\begin{array}{l}2,3,6,8 \\
2,3,6,8\end{array}$ \\
\hline
\end{tabular}

CYCLE TIME

Full open to full close:

2 way -18 seconds

3 way -24 seconds

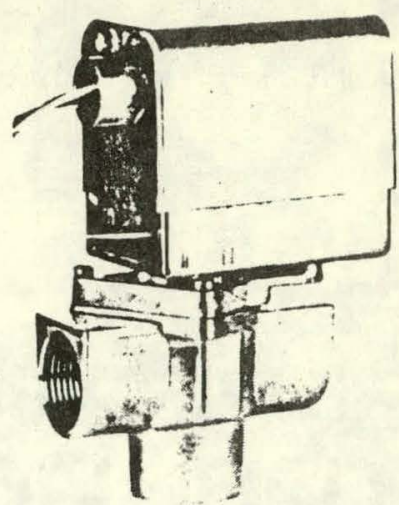

The new 552 Series, 1", high capacity valve is motor driven to both the open and the closed position. It is designed for both chilled water and hot water on larger fan coil applications.

The manual lever is self-unlocking upon energization of the opening coil.

\section{"BR" SERIES REVERSIBLE MOTOR OPERATED VALVES FOR HEATING AND COOLING FAN COIL APPLICATION}

DESIGNED TO OPERATE ON HIGH DIFFERENTIAL APPLICATIONS

\begin{tabular}{|c|c|c|c|c|c|c|}
\hline $\begin{array}{l}\text { Valve } \\
\text { Series }\end{array}$ & $\begin{array}{l}\text { Pipe Connections and Diameters } \\
\text { (Threaded Valve Connections are NPT } \\
\text { Conduit Connector is } 1 / 2 \text { " STD) }\end{array}$ & Model & $\begin{array}{l}\text { Valve Po } \\
\text { Service } \\
\text { End B }\end{array}$ & $\begin{array}{l}\text { By-Pass } \\
\text { End A }\end{array}$ & $\begin{array}{l}\text { Service } \\
\text { Port Cv } \\
\text { Factor } \\
\text { (Based on } \\
\text { U.S. gal.) }\end{array}$ & $\begin{array}{l}\text { Optional } \\
\text { Equipment } \\
\text { (See } \\
\text { Below) }\end{array}$ \\
\hline $681-B R-307$ & 1/2" Pipe Thread Female & 2-way & $5 / 16^{\prime \prime}$ & & 2.4 & $2,3,4,6,8,9$ \\
\hline 681-BR-309 & 1/2" Pipe Thread Female & 3-way & $7 / 16^{\prime \prime}$ & $5 / 16^{\prime \prime}$ & 5.5 & $2,3,4,6,8,9$ \\
\hline 687-BR 307 & $\begin{array}{l}45^{\circ} \text { (SAE) Inverted Flare } \\
1 / 2^{\prime \prime} \text { Copper (5/8" O.D.) } \\
45^{\circ} \text { (SAE) Inverted Flare }\end{array}$ & 2-way & $5 / 16^{\prime \prime}$ & & 2.4 & $2,3,4,6,8,9$ \\
\hline $687 \cdot B R-309$ & $\begin{array}{l}45^{\circ} \text { (SAE) Inverted Flare } \\
1 / 2^{\prime \prime} \text { Copper (5/8" O.D.) }\end{array}$ & 3-way & $7 / 16^{\prime \prime}$ & $5 / 16^{\prime \prime}$ & 4.4 & $2,3,4,6,8,9$ \\
\hline 672-BR-307 & 3/4" Pipe Thread Female & 2-way & $5 / 16^{\prime \prime}$ & & 2.4 & $2,3,4,6,8,9$ \\
\hline 672-BR-309 & 3/4" Pipe Thread Female & 3-way & $7 / 16^{\prime \prime}$ & $5 / 16^{\prime \prime}$ & 5.5 & $2,3,4,6,8,9$ \\
\hline 654-BR-307 & 5/8" O.D. Sweat & 2-way & $5 / 16^{\prime \prime}$ & & 2.4 & $2,3,4,6,8,9$ \\
\hline 654-BR-309 & 5/8" O.D. Swveat & 3 way & $7 / 16^{\prime \prime}$ & $5 / 16^{\prime \prime}$ & 1.8 & $, 2,3,4,6,8,9$ \\
\hline 6.35-RR-307 & 7/8" O.D. Sweat & 2-way & $5 / 16^{\prime \prime}$ & & 2.4 & $2,3,6,8$ \\
\hline 635-BR-309 & 7/8" O.D. Sweat & 3-way & $7 / 16^{\prime \prime}$ & b/16". & b.4 & $2,3,6,8$ \\
\hline
\end{tabular}

\section{STEAM AND HIGH TEMPERATURE WATER VALVES}

Same as above except first number after "BR" changes to " 4 " EXAMPLE: $681 B R 407$

See page four for 400 type specifications.

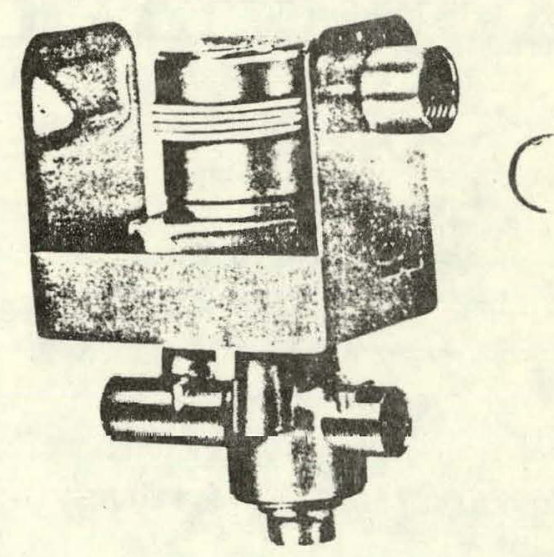

The "BR" Series valve is motor driven to the open and the closed position. Its high differential capabilities make it a real "trou ble job" problem sulver,

\section{ORDERING EXAMPLE}

\section{Valve Series} 654-BR-309

Obtain Valve Sarias No from above table of

standard

Valve Models.
18

A standard 18" lead is supplied wlth all valves. Lead Leinthis other than 18" can be supplied. Valves ordered with auxiliary sealed switches only available with 18 "leads.

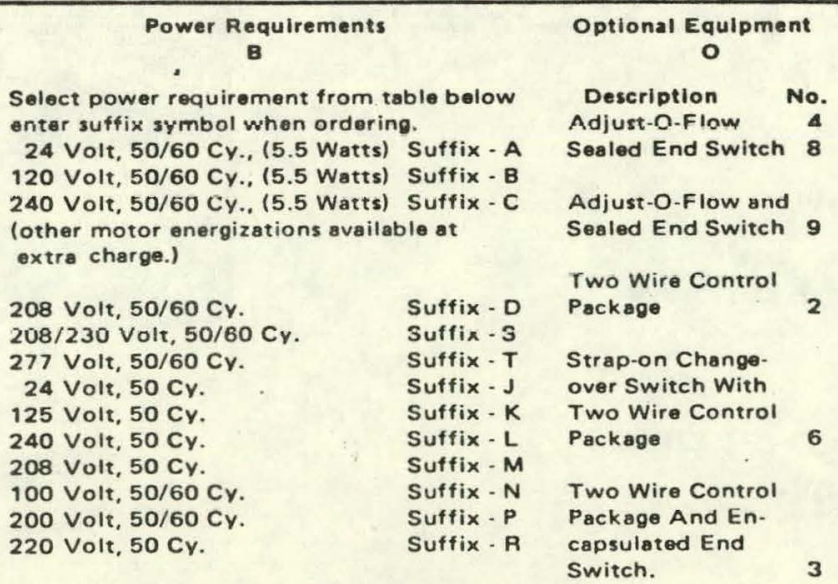

654-BR-309-18BO- DESCRIPTION: 5/8" O.D. SWEAT VALVE, THREE-WAY, 120 VOLT, 18" LEADS Begin with complete Valve Series Number. Add letters and numbers denoting Lead Length.

\section{AUXILIARY SWITCH}

For control panel monitoring or operating auxiliary equip. ment on standsrd modeis. It is octuated on the valve opening cycle and is reset as value closes. For pilot duty only.

\section{STRAP.ON}

SUMMER/WINTER CHANGE OVER SWITCH

Encapsulated switch complete Iy sealed against moisture and factory wired to operate valve motor only. It will operate on thermostat heating contacts with water temperatures of $88^{\circ} \mathrm{F}$. or higher. With water tempera tures of $60^{\circ} \mathrm{F}$ or lower the valve will operate or thermostat cooling contacts. 


\section{PREFIXES FOR CONDUIT TYPES}

The prefixes "61", "62", "63", "64", and "65" before the valve part number designates the following:

\begin{tabular}{|l|l|l|l|}
\hline Preflx & Countries & Condult & \multicolumn{1}{|c|}{ Type of Valve Connection } \\
\hline "61" & Finland only & $13 / 16-18$ & BSP.PL or $16 M M(1 / 2 "$ Nom.) Water Tube Sweat \\
"62" & Spain only & $3 / 4-18$ & BSP-TR or $16 M M(1 / 2 "$ Nom.) Water Tube Sweat \\
"63" & E.E.C. & $3 / 4-18$ & BSP.PL or 16MM $(1 / 2 "$ Nom.) Water Tube Sweat \\
"64" & U.S.A. (Str. Pipe) & $1 / 2-14$ & NPT or 5/8" O.D. (1/2" Copper) Water Tube Sweat \\
"65" & United Kingdom & $3 / 4-16$ & BSP - PL or .596" O.D. (1/2" Nom.) Water Tube Sweat \\
\hline
\end{tabular}

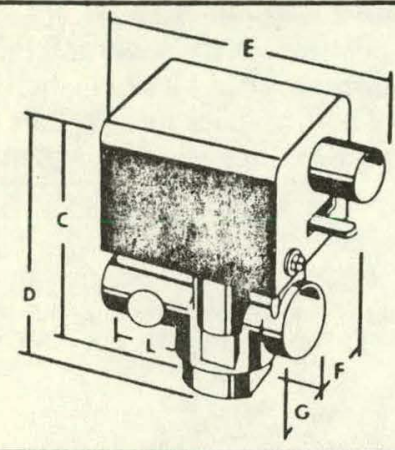

\begin{tabular}{|l|l|r|r|r|r|r|r|}
\hline \multicolumn{1}{|c|}{ ERIE } & MEASUREMENT & C & D & E & F & G & L \\
MOTORTROLS & & & & & & & \\
\hline "BR" SERIES & CENTIMETERS & 12.7 & 14.5 & 11.2 & 3.6 & 2.6 & 9.0 \\
& INCHES & 5.0 & 5.7 & 4.4 & 1.4 & 1.0 & 3.5 \\
\hline \multirow{2}{*}{552 SERIES } & CENTIMETERS & 14.5 & 16.5 & 11.2 & 3.6 & 3.1 & 12.0 \\
& INCHES & 5.7 & 6.6 & 4.4 & 1.4 & 1.2 & 4.6 \\
\hline
\end{tabular}

\section{WIRING DIAGRAMS}

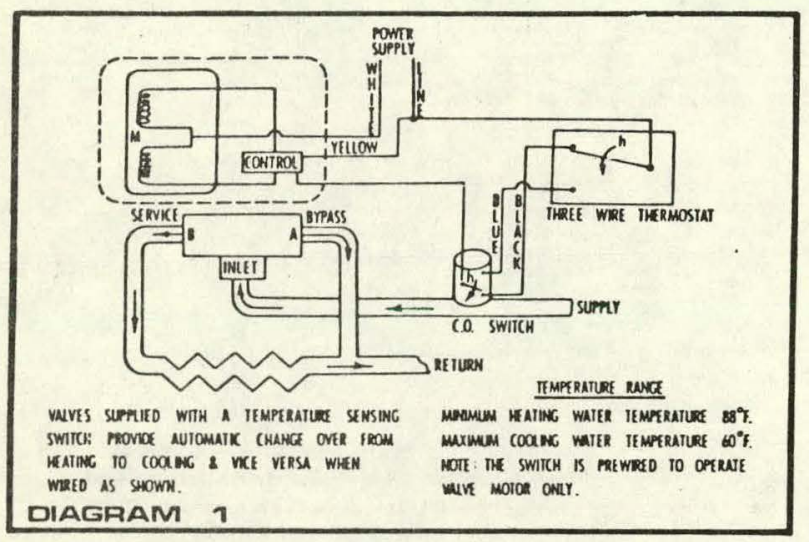

Diagram No. 1: Reversible motor valves, 552 and "BR" Series with temperature sensing switch. Requires constant power supply.
Diagram No. 2 :

Reversible motor valves, 552 and "BR" Series with 3-wire thermostat.
INVERTCD FLARE TYPE CONNECTIONS

FOR USE WITH 687 "BR" SERIES VALVES

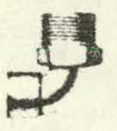

A

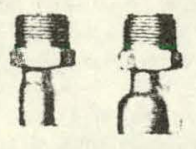

C

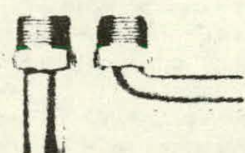

E
VALVE BODY MACHINED TO RECEIVE ANY UP THESE FITTINGS:

A. Inverted flare nut and elbow assembly, female. for $5 / 8^{\prime \prime} \cap \cap$ twhing Part No. 436A214-1. Length of fitting 15/16".

B. Inverted flare nut and coupling assembly, female, for 5/8" O.D. tubing Part No. 436A220. Length of fitting $1-11 / 16^{\prime \prime}$.

C. Inverted flare nut assembly, female, for 5/8" to $7 / 8$ " O.D. tubing Part No. 436A252. Length of fitting 1 - 27/32".

Inverted flare nut and nipple assembly, male, for 5/8" O.D. tubing Part No. 436A229-3. Length of fitting 3".

E. Inverted flare nut and elbow assembly, male, for 5/8" O.D. tubing Part No. 436A214-4. Length of fitting 1 - 15/16".

Fits directly to shut-off valve.
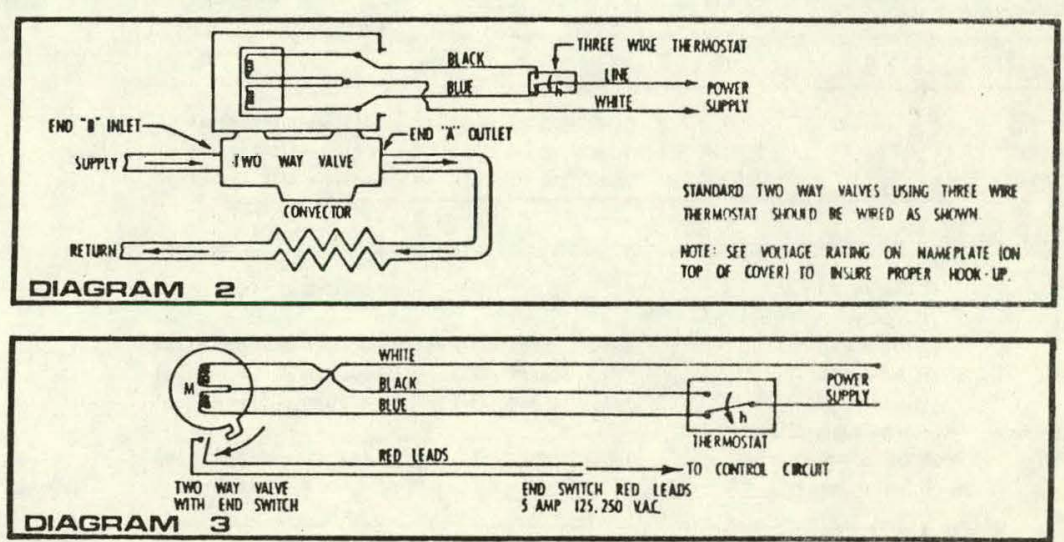

Diagram No. 3: Reversible motor valves, 552 and "BR" Series with 3-wire thermostat and end switch.
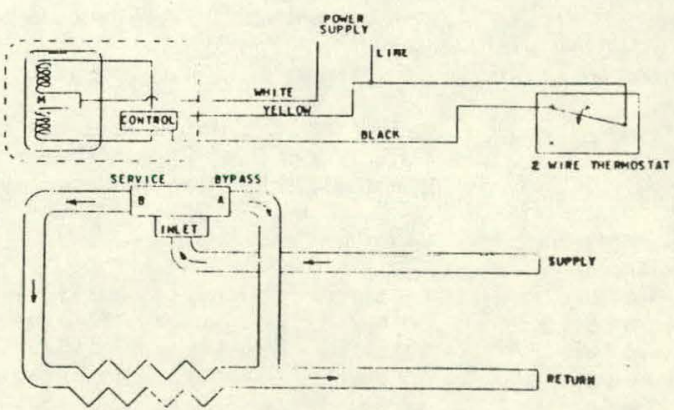

Diagram No. 4: Reversible motor valves, 552 and "BR" Series, having two-wire control option. Requires constant power supply. 
SPECIFICATIONS:

\begin{tabular}{|c|c|}
\hline \multirow{3}{*}{$\begin{array}{l}\text { Electrical } \\
\text { Rating: }\end{array}$} & U.S. STANDARD \\
\hline & $\begin{array}{l}24 \text { Volt, } 50 / 60 \mathrm{cy} . \text {, (5.5 watts) } \\
120 \text { Volt, } 50 / 60 \mathrm{cy} . \text { ( (5.5 watts) } \\
240 \text { Volt, } 50 / 60 \mathrm{cy} \text {, (5.5 watts) }\end{array}$ \\
\hline & (Other motor energizations available) \\
\hline $\begin{array}{l}\text { Electrical } \\
\text { Wiring: }\end{array}$ & $\begin{array}{l}\text { Wire leads } 18^{\prime \prime} \text { long through a conduit fitting } \\
\text { (No. } 18 \text { AWG } 105^{\circ} \mathrm{C} \text { Appliance Wire) }\end{array}$ \\
\hline
\end{tabular}

Rubber Goods:

300 Iype: Cunpuunded for hot water and chilled water 400 Type: $\quad$ Compounded for hot water and steam service

Temperature Limits:

300 Type:

400 Type:

Water $-200^{\circ} \mathrm{F}$, ambient temperature $-110^{\circ} \mathrm{F}$ Water $-260^{\circ} \mathrm{F}$, ambient temperature $-180^{\circ} \mathrm{F}$ Steam - 15 PSI maximum system pressure

System Pressure: $\quad 200$ P.S.I. Maximum

\section{"BR" SERIES}

$7 / 16$ " Port

5/16" Port

3/16" Port

50 P.S.I opening or closing pressure differential 100 P.S.I. opening or closing pressure differential 200 P.S.I. opening or closing pressure differential

\section{SERIES}

$\begin{array}{lll}\text { 2-way } & \text { B } \rightarrow \text { A Flow } \\ \text { 3-way } & \text { (Common Inlet) } \\ \text { Inlet } \rightarrow \text { B } & .6^{\prime \prime} & \text { port }-25 \text { psi pressure differential } \\ \text { Inlet } \rightarrow \text { A } & .650^{\prime \prime} \text { port }-25 \text { psi pressure differential } \\ \text { Inlet } \rightarrow \text { A } & .650^{\prime \prime} \text { port }-20 \text { psi pressure differential } \\ \text { (Common Outlet) } & .5^{\prime \prime} \text { port }-35 \text { psi pressure differential } \\ \text { 3-way } & \text { or B } \rightarrow \text { outlet } \\ \text { A } \rightarrow \text { outlet } & .650^{\prime \prime} \text { port }-15 \text { psi pressure differential } \\ & .5^{\prime \prime} \text { port }-25 \text { psi pressure differential }\end{array}$

\section{METRIC}

Electrical Rating: Same as U.S. Standards

Electrical

Wiring:

Wire leads $0.45 \mathrm{~m}$ long through a conduit fitting (1.5 sq. mm $105^{\circ} \mathrm{C}$ Appliance Wire)

Temperature Limits:

300 Type:

400 Type:

Water $-94^{\circ} \mathrm{C}$, ambient temperature $\cdot 43^{\circ} \mathrm{C}$ Water $-127^{\circ} \mathrm{C}$, ambient temperature $-82^{\circ} \mathrm{C}$ Steam - $1.05 \mathrm{kgf} / \mathrm{cm}^{2}$ maximum system pressure

System Pressura:

$14 \mathrm{~kg} / \mathrm{cm}^{2}$ maximum

$15 ?$ muil Port

$12.7 \mathrm{~mm}$ Port

$11 \mathrm{~mm}$ Port

$8 \mathrm{~mm}$ Port

5 mm Port

$1.8 \mathrm{~kg} / \mathrm{cm}^{2}$ nnaning or closing pressure differential $2.1 \mathrm{~kg} / \mathrm{cm}^{2}$ opening or closing pressure differential $3.5 \mathrm{~kg} / \mathrm{cm}^{2}$ opening or closing pressure differential $7 \mathrm{~kg} / \mathrm{cm}^{2}$ opening or closing pressure differential $14 \mathrm{~kg} / \mathrm{cm}^{2}$ opening or closing pressure differential

1. Suitable for static test up to 300 P.S.I. or $21 \mathrm{~kg} / \mathrm{cm}^{2}$.

2. Valve part numbers on $6878 R$ do not include fittings. Fittings must be ordered separately.

3. In all cases on 2-way valves, flow should be from Port B to Port A

4. Valves with sealed end switches are available with $18^{\prime \prime}$ leads only. RATING: 5 AMP, 250 V.A.C.

\section{ERIE MANUFACTURING COMPANY}

4000 S. 13th St., Milwaukee, Wis. 53221

Tel: (414) 483-7780 Telex: 2-6867

(Canada) Ltd. Box 880, Stouffville, Ont.

Erie-Clack-Europ N. V., Wolfstee B 2410 Herentals, Belgium

\section{IMPORTANT NOTE FOR FAN COIL INSTALLATIONS}

\section{INSTALLATION}

These high performance, high differential capability valves are motor driven both to the open and the closed position. A three-wire, S.P.D.T. thermostat is required, or a two-wire thermostat can be used when options 2, 3 or 6 are added. For optional control packages, 2, 3 or 6, a constant power source is required to the valve. (See wiring diagrams.)

\section{TWO-WAY VALVES}

When installing a two-way valve, the flow direction is from end $B$ to end $A$. Port markings $A$ and $B$ are located on the bottom of the valve body.

\section{MOUNTING}

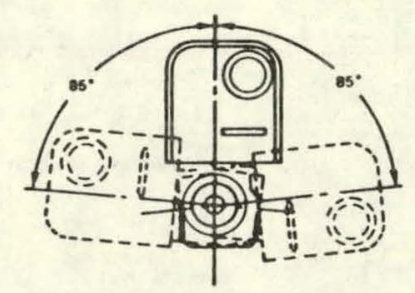

Valve motor and gear train will not function properly when wet. Motor housing must be protected from drippage. Motor housing need not be protected from condensation on its attached valvo body when instolled in hotizontal niping If valve is positioned within $85^{\circ}$ of upright position. (See sketch.) Electric valves, like all other mechanic.. equipment are subject to failure and should be installed with $\mathrm{a}$ degree of accessibility to enable quick and economical servicing or repiacement.

\section{THREE-WAY VALVES}

When installing three-way diverting valves, end $B$ is the service end and end $A$ is the bypass end. The inlet port is unmarked. Port markings $A$ and $B$ are located on the bottom of the valve body.

Threo-way valves supplied with option 6 (two-wire control package and strap-on change-over switch provide autornatic change-over from heating to cooling and vice-versa when wired as shown in diagram No. 1.)

With woter temperature of $88^{\circ} \mathrm{F}$ or higher, the valve will operate on the thermostat heating contacts. With water temperature of $60^{\circ} \mathrm{F}$ or lower, the value will uperate on the thermostat cooling contarts

Three-way valves, piped with a common outlet, are de-rated as shown in the specifications.

\section{VALVES WITH SWEAT CONNECTIONS}

The two asbestos protection shields must be used between the valve liousing and the valve body to protect the mechanism and externat wires from flame and excessive heat. The asbestos shields are factory assembled and may be removed after leak testing. On valves with manual operator place lever in manually open position before soldering.

\section{INSTRUCTIONS FOR SWEATING}

Use only lead or tin base solder with melting point below $600^{\circ} \mathrm{F}$. Do not overheat valve body.

Ends of water supply tubing must be thoroughly clean for a minimum distance of 1 ' from end. 


\section{TA-1501}

\section{ELECTRIC CONTROLLER ROOM THERMOSTATS TWO-POSITION, HEATING}

For on-off control with heat anticipation of low current devices such as actuators, relays and motor pull-up coils.

Bimctal opcrated snap action SPST switch. Color coded 6" leads. .2 to 1 amps adjustable heat anticipation. Differential $2^{\circ} \mathrm{F}$. Mounts on flush or surface switch box, or directly on wall (24 volt only). Dimensions: $4-3 / 8^{\prime \prime}$ high $\times 2-7 / 8^{\prime \prime}$ wide $\times 1-5 / 8$ " deep.

\section{ACCESSORIES:}

AT-101 Lock cover kit

AT-104 Dial stop pins

AT-136 Title plates (day, night, heat, cool)

AT-504 Plaster hole cover kit (small)

AT-505 Surface mounting base

AT-546 Auxiliary mounting plate

AT-602 Selector switch sub-base DP4T

AT-603 Selector switch sub-base one DP4T, one DPDT

AT-1103 Wire guard

AT-1104 Case aluminum guard

AT-1105 Plastic guard

AT-1155 Plastic guard

AT-1165 Plastic guard

Tool \#11 Calibration wrench
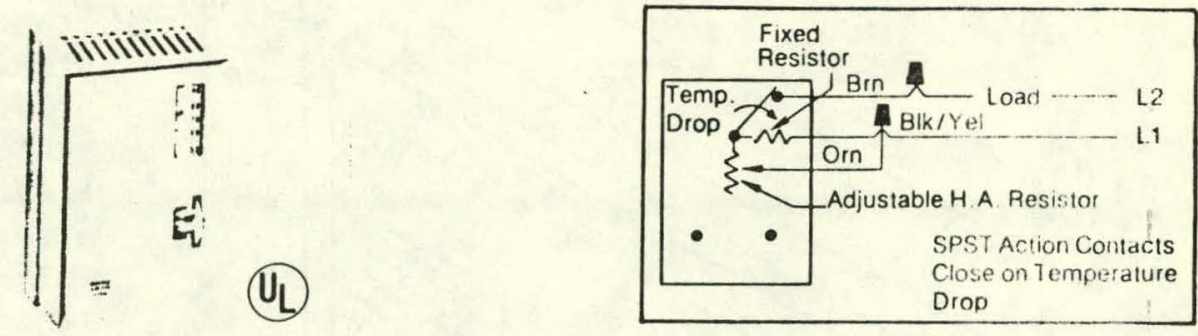

\begin{tabular}{|c|c|c|c|c|c|c|}
\hline \multirow{2}{*}{$\begin{array}{c}\text { Part } \\
\text { Number }\end{array}$} & $\begin{array}{c}\text { Control } \\
\text { Dial } \\
\text { Range }\end{array}$ & \multicolumn{2}{|c|}{ Full Load Amps } & \multicolumn{2}{c|}{ Locked Rotor Amps } & Pilot Duty VA \\
\cline { 2 - 7 } & $24 / 120$ Vac & 240 Vac & $24 / 120$ Vac & 240 Vac & $24 / 120 / 240$ Vac \\
\hline TA-1501 & $\begin{array}{c}55-85^{\circ} \mathrm{F} \\
\left(13-29^{\circ} \mathrm{C}\right)\end{array}$ & 1 & 1 & 6 & 6 & - \\
\hline
\end{tabular}

OPTIONS: Add "dash-number" (-XXX) suffix to base part number for desired option.

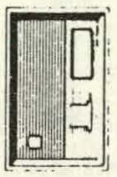

Standard (OF) $-116\left({ }^{\circ} \mathrm{C}\right)$

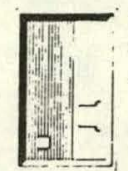

-400 (아)

$-410\left({ }^{\circ} \mathrm{C}\right)$

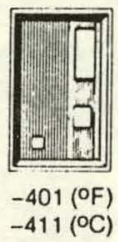

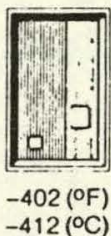

$-412\left({ }^{\circ} \mathrm{C}\right)$

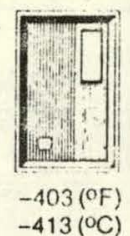

$-413\left({ }^{\circ} \mathrm{C}\right)$

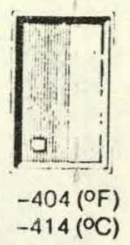

$-60110^{\circ} \mathrm{F}$ night depression 120V Fahrenheit dial \& thermometert $-60210^{\circ} \mathrm{F}$ night depression 24V Fahrenheit dial \& thermometer $-60310^{\circ} \mathrm{F}$ night depression 240V Fahrenheit dial \& thermometer $\dagger$

†Normally, night depression is controlled by a centrally located time clock such as AE-174 or AE-178, or by selector switch sub-bases (AT-602 or AT-603).

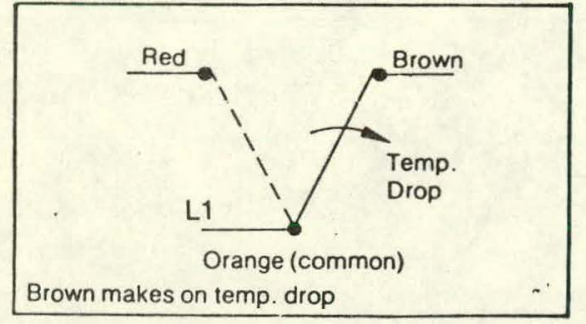

Bimetal operated snap action SPDT switch. Color coded $6^{\prime \prime}$ leads. Differential $2^{\circ} \mathrm{F}$. Mounts on flush or surface switch box or directly to wall (24 volt only). Dimensions: $4-3 / 8^{\prime \prime}$ high $\times 2-7 / 8^{\prime \prime}$ wide $\times 1-5 / 8$ " deep.
TC. $1101 / 1102 / 1103$

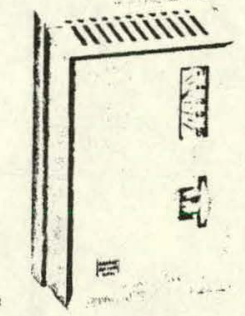

\section{ELECTRIC CONTROLLER ROOM THERMOSTATS TWO-POSITION, HEATING ANDIOR COOLING}

For low or line voltage on-off conirol of fan coils, fans, motor starters and contactors.

\begin{tabular}{|c|c|c|c|c|c|c|}
\hline \multirow{2}{*}{$\begin{array}{l}\text { Part } \\
\text { No. }\end{array}$} & \multirow{2}{*}{$\begin{array}{c}\text { Control } \\
\text { Dial } \\
\text { Range }\end{array}$} & \multicolumn{2}{|c|}{ Full Load Amps } & \multicolumn{2}{|c|}{ Locked Rotor Amps } & \multirow{2}{*}{$\begin{array}{l}\text { Pilot } \\
\text { Duty } \\
\text { (VA) }\end{array}$} \\
\hline & & $24 / 120 \mathrm{Vac}$ & $240 \mathrm{Vac}$ & $24 / 120 \mathrm{Vac}$ & $240 \mathrm{Vac}$ & \\
\hline & $\begin{array}{c}55-85^{\circ} \mathrm{F} \\
\left(13-29^{\circ} \mathrm{C}\right)\end{array}$ & \multirow{3}{*}{4.4} & \multirow{3}{*}{2.2} & \multirow{3}{*}{26.4} & \multirow{3}{*}{13.2} & \multirow{3}{*}{$\begin{array}{c}40 @ \\
24 \mathrm{Vac} \\
210 @ \\
120 / 240 \\
\text { Vac }\end{array}$} \\
\hline TC-1102 & $\begin{array}{c}45-75^{\circ} \mathrm{F} \\
\left(7-23^{\circ} \mathrm{C}\right)\end{array}$ & & & & & \\
\hline TC-1103 & $\begin{array}{l}70-100^{\circ} \mathrm{F} \\
\left(21-37^{\circ} \mathrm{C}\right)\end{array}$ & & & & & \\
\hline
\end{tabular}




\section{Tight Seal Damper-Insulated Blades Opposed Blade Operation \\ SPECIFICATIONS}

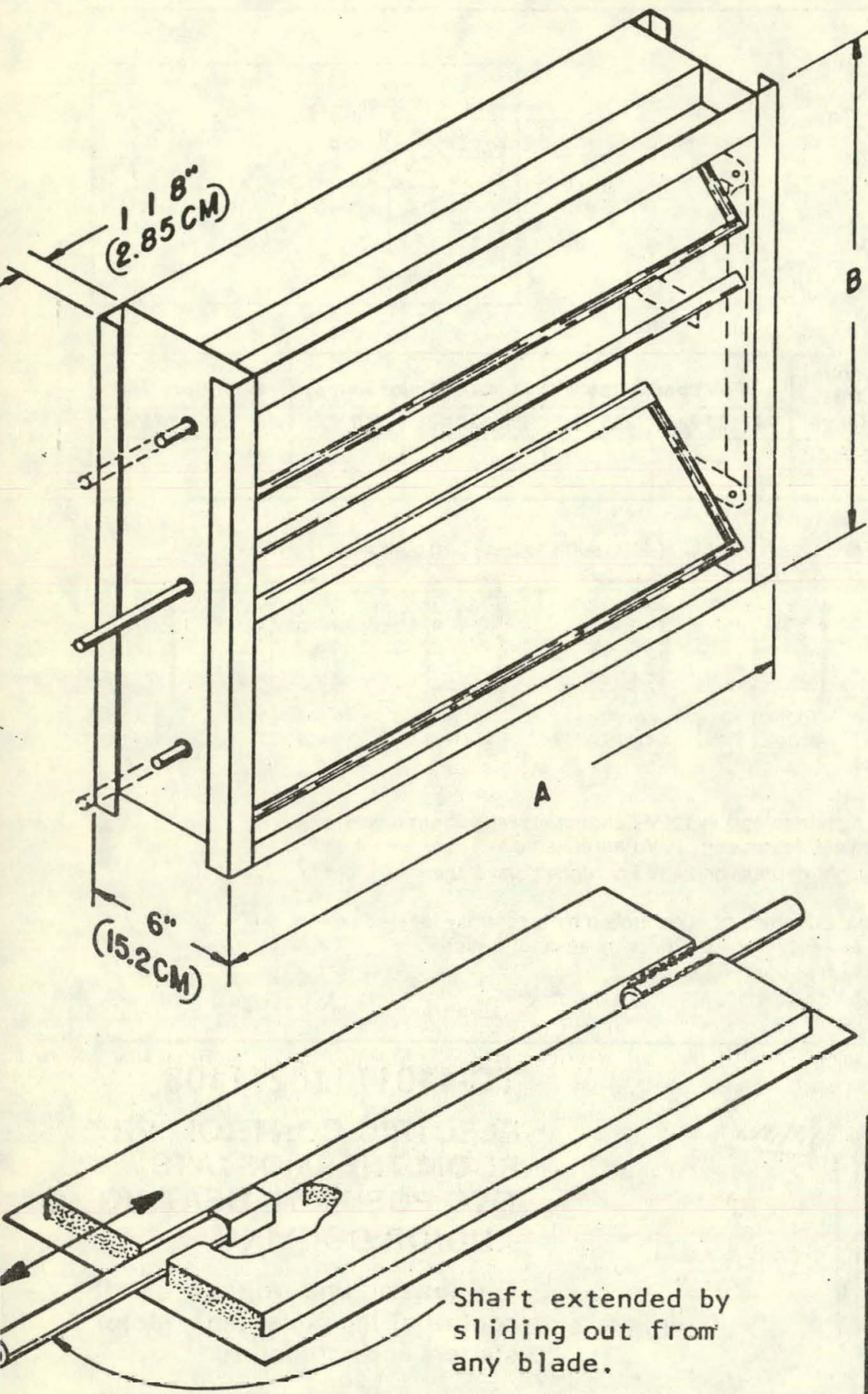

1. All welded construction.

2. Frame constructed of 14 ga. galvanized steel. Open beam type construction provides integral top $\&$ bottom blade stops.

3. Blades feature double skin construction with $14 \mathrm{ga}$. channel reinforcement

8 welded between the skins, forming a structural closed beam; with full length thermal insulation.

4. Blades pivot on $1 / 2^{\prime \prime}(1.27 \mathrm{~cm})$ dia. CRS stub shafts in sintered bronze selflubricating bearings.

5. Shaft extension feature is standard on any blade shaft.

6. Blade linkage is completely enclosed in the side frame.

7. Maximum blade span is $72^{\prime \prime}(183 \mathrm{~cm})$. Units with longer spans are made in multiple sections and require jack shafts.

8. Maximum blade deflection is $1 / 8^{\prime \prime}(.32 \mathrm{~cm})$ at center, for a $72^{\prime \prime}(183 \mathrm{~cm})$ long blade at 4 "' W.G.

9. Extruded neoprene \& polyurethane is inserted in all blade edges and ends affording extremely efficient tight shut-off.

10. Maximum duct velocity is $3000 \mathrm{ft} . / \mathrm{min}$. 11. Maximum static pressure is 6' W.G. for a $72^{\prime \prime}(183 \mathrm{~cm})$ blade length.

12. Maximum height, for a single section, is $84^{\prime \prime}(213 \mathrm{~cm})$.

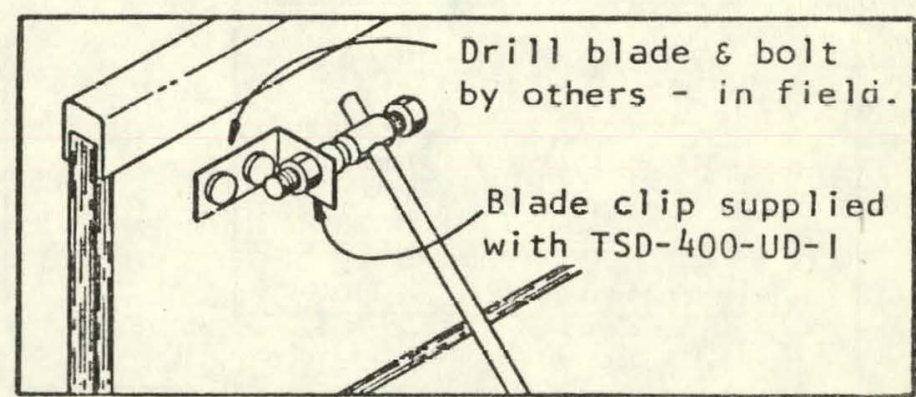

MODEL NO.

DESCRIPTION

$\square$ TSD-400-UD-1

Blade clip is shipped loose with thru bolts to permit positioning on any

TSD-400-UD-0 blade when actuator is mounted inside the duct.

Any shaft on the opposite side of the damper from the linkage may be extended as much as 6 inches from the blade to drive the damper when actuator is mounted outside the duct

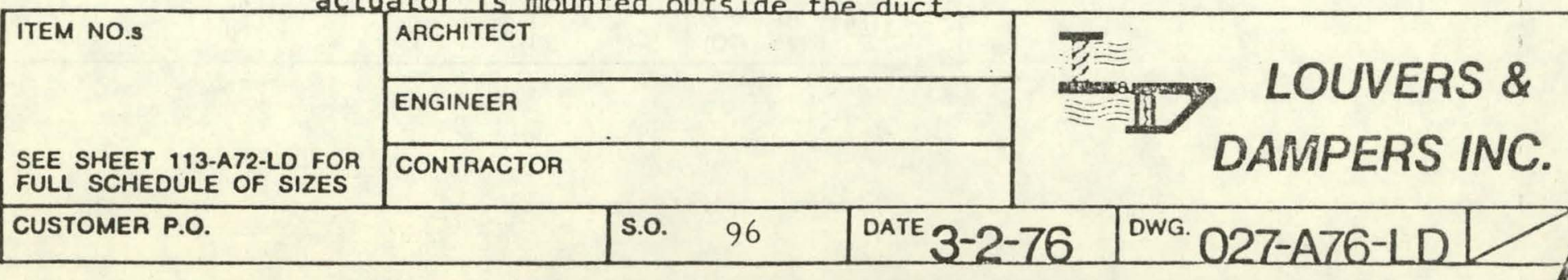




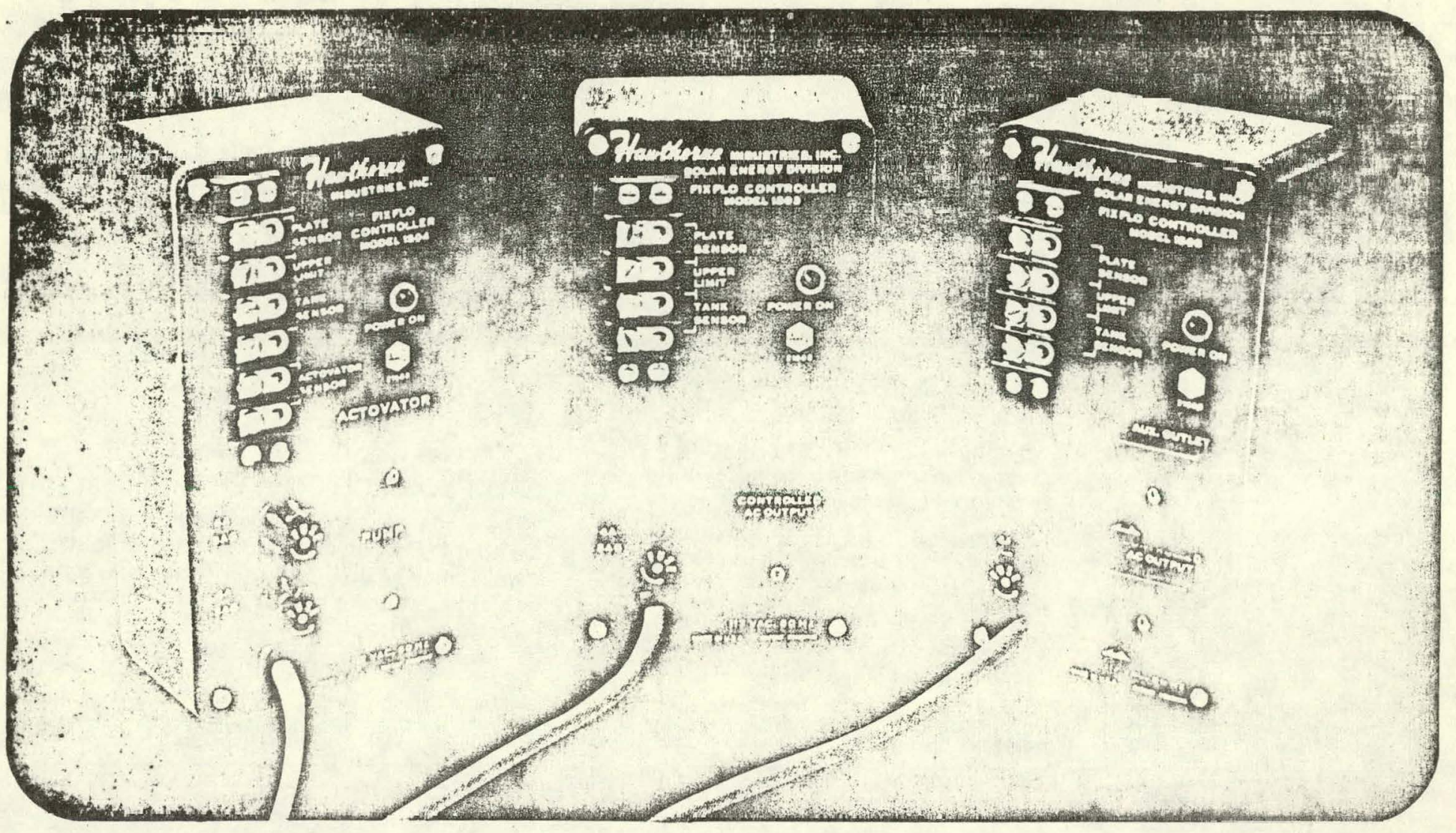

\section{$100 \%$ SOLID STATE}

\section{DIFFERENTIAL TEMPERATURE CONTROLS FOR YOUR SOLAR SYSTEMS}

\section{A COMPLETE FAMILY OF VERSATILE, HIGH QUALITY CONTROLLERS WHICH PROVIDE A COST-EFFECTIVE SYSTEM COMPONENT FOR VIRTUALLY EVERY APPLICATION.}

- Applied Research Laboratories safety tested and approved.

- Designed for simple installation with a minimum of labor.

- No professional trades required for installation.

- One year replacement warranty.

$100 \%$ true solid state epoxy encapsulated circuitry.

- Maximum quality control-each unit is individually tested.

- Durable and attractive black phenolic case with black anodized aluminum face plate.

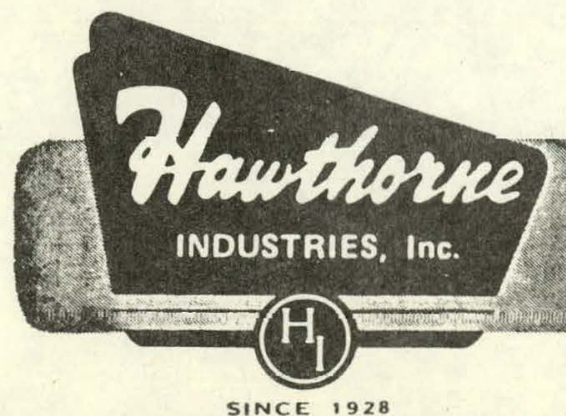

- Fused to protect circuitry from output overload.

- Power line surge and lightning protected.

- High reliability, low voltage sensors.

- 4 ampere (480 watt) controlled A.C. output.

- Stable operation on line voltage from 105-130 VAC.

- Transformer line isolation rated at 1600 VAC.

- No minimum or maximum wire length to sensor.

- Two standard sensors supplied with each differential control.

- Instant mounting with pressure sensitive backing material. 

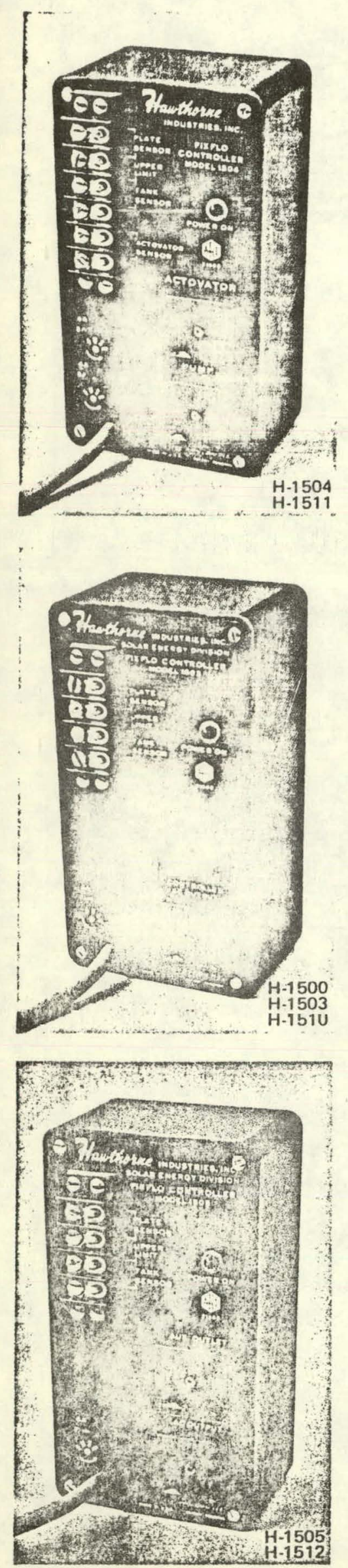

MODEL \# H-1500

\section{THE ACTOVATOR}

The $\mathrm{H}-1500$ Actovator control is a low voltage controlled solid state switch to power auxiliary equipment in a solar system.

Typical Applications:

- Auto drain control for thermo-siphon solar systems as freeze protection (solenoid valves)

- To power a small heating element in a solar collector as frost protection.

- Switching unit to shift the output of a solar system from one storage tank to another at a predetermined temperature.

- Switching unit to turn on an auxiliary heating element to maintain a minimum temperature in a solar storage tank.

- To switch a solar home heating system from solar to conventional auxiliary heating at a predetermined temperature.

- Let your ingenuity be your guide.

Features:

- Low voltage control 5.1 VAC maximum short circuit current 4 ma.

- Output may be selected for 120 VAC power normally on or off.

- Controller power requirement 4 watts, 117 VAC, $60 \mathrm{HZ}$.

- Light emitting diode power on indicator.

- 4 amp. (480 watt) controlled output.

- Sensor activates or deactivates circuit by shorting.

\section{MODEL \# H-1503} an $160^{\circ}$ Disis: FIXFLO CONTROLLER CX:I $=3^{\circ}$ ij,FI.

The Model \#H-1503 Fixflo controller is a versatile solid state differential temperature control with the following features:

- 4 amp. (480 watt) controlled A.C. output.

- Positive on/off action for pump, relay or solenoid control (no chatter) no oscillation.

- $+5^{\circ} \mathrm{F}$ turn on differential.

- Linear control from $30^{\circ}-220^{\circ} \mathrm{F}$.

- Sensor voltage 8.3 VDC maximum short circuit current $4.15 \mathrm{ma}$.

- Low power requirement 4 watts, 120 VAC.

- Upper temperature limit control-stops pump circulation with a storage tank temperature of $165^{\circ} \mathrm{F}$ optional with added sensor.

- Frost cycle-starts pump circulation with a collector plate temperature of $35^{\circ} \mathrm{F}$ and will continue to circulate water from the storage tank until the plate temperature reaches $45^{\circ} \mathrm{F}$, then stops and repeats this cycle as often as required to hold the collector above freezing. (Note: not recommended in areas where very frequent freezing conditions occur). Optional with special sensor.
MODEL \# H-1504

\section{FIXFLO CONTROLLER WITH ACTOVATUH}

The Model \#H-1504 is identical to the \#H-1503 Fixflo controller, with the addition of the features of the Model \#H-1500 (the Actovator). In this unit, the normally on or normally off A.C. power is controlled by a normally open or normally closed sensor.

\section{MODEL \#H-1505}

FIXFLO CONTROLLER WITH DUAL OUTLET The Model \#H-1505 is identical to the \#1503 with the addition of an auxiliary (dual) outlet which may be used to power two pumps, one on either side of a heat exchanger, or operate a relay or solenoid valve.

MODEL \# H-1510

\section{VARIFLO CONTROLLER}

The Model $\# \mathrm{H}-1510$ is a versatile solid state differential temperature controller with a variable flow rate feature.

This controller must be used with a pump that is speed controllable. The following pumps hav been tested and found to perform well with the Model \#H-1510 control.
March Model $821 \mathrm{BR}$ and 809
Teel Model 1P761" and 1P760
Sundstrand Model LA4302*
Grundfos Model UPS20-42F" and UP25-42S
Note: ${ }^{*}$ Cast iron pump housing. Do not use for direct circulation of domestic water.

The March Model 809 and Teel Model 1P760 pumps are not recommended for use with the Model \#H-1510 control, even with a single panel installation, as their flow rates are already too low; thus, there is no advantage to speed control of these pumps. However, they din speed control, and may fit a special requirement.

The Model \#H-1510 is a true differential temperature controller. The flow rate (speed) of the pump is controlled by the amount of differential. A very slow flow rate is started with a $3-4^{\mathrm{O}} \mathrm{F}$ differential and is increased to full pump flow when a $23-24^{\circ} \mathrm{F}$ differential is reached. 


\section{URE CONTROLS FOR YOUR SOLAR SYSTEMS}

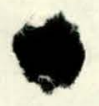

\section{THE ADVANTAGES OF AUTOMATIC FLOW RATE CONTROL ARE MANY}

1. The proper flow rate through the solar collector is automatically adjusted based on the amount of energy to be gained, holding plate temperatures down and increasing overall system performance.

2. Eliminates frequent pump cycling, thus extending pump life.

3. All recommended pump motors operate at lower temperatures throughout their speed control range, extending expected pump life.

4. Only the energy required for efficient system operation is used resulting in a power savings.

5. System installation cost is lowered by eliminating the plumbing bypass around the pump commonly used to adjust for a desired flow rate.

6. The proper flow rate is automatically established, eliminating time-consuming bypass adjustments.

The \#H-1510 Variflo control also offers upper temperature limit and frost cycle features as explained in the last 2 items of the $\# \mathrm{H}-1503$ with the optional sensors.

\section{MODEL \# H-1511}

\section{VARIFLO CONTROLLER WITH ACTOVATOR}

The \# $\mathrm{H}-1511$ Variflo control is identical to the \#H-1510 with the addition of the features of the Actuator Model \#H-1500. In this unit, the normally on or normally off A.C. power is controlled by normally open or normally closed sensors.

\section{MODEL \# H-1512}

\section{VARIFLO CONTROLLER WITH DUAL OUTLET}

The Model \#H-1512 Variflo controller is identical to the Model $\# \mathrm{H}-1510$ with the addition of an auxiliary A.C. outlet (dual outlet), which may be used to power two pumps, one on either side of a heat exchanger. (Note: This auxiliary outlet is also speed controlled and is not suitable for relay or solenoid valve control).

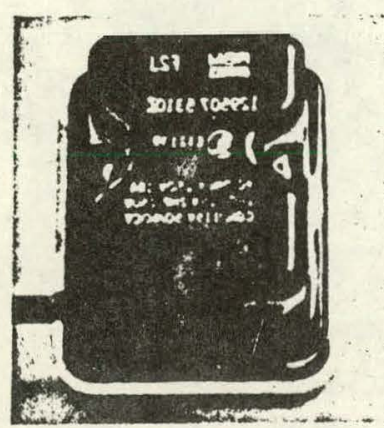

MUUEL \# H-1530

\section{RELAY PACKAGE}

The \#H-1530 is an accessory for Models $\# \mathrm{H}-1503$ and $\# \mathrm{H}-1500$ controllers, extending output load capabilities to 1 h.p.

A must if pump motor has high starting current or running current above 4 amps.

The relay package comes complete with conduit mounting and A.C. line cord for connection to the controller.

\section{SENSORS}

$\# \mathrm{H}-1525$ Standard thermistor sensor $10 \mathrm{~K}$ ohm at $25^{\circ} \mathrm{C}, 1 \%$ curve matched.

\section{OPTIONAL ACCESSORIES}

- \#H-1514 Upper temperature limit $85^{\circ} \mathrm{F}$. Pool \#H-1515 Upper temperature limit $165^{\circ} \mathrm{F}$. Hot water. $\# \mathrm{H}-1520$ Frost cycle sensor with thermistor $35^{\circ} \mathrm{F}$. \#-1535 Mounting Plate \#H-1540 Rain-tite Cover

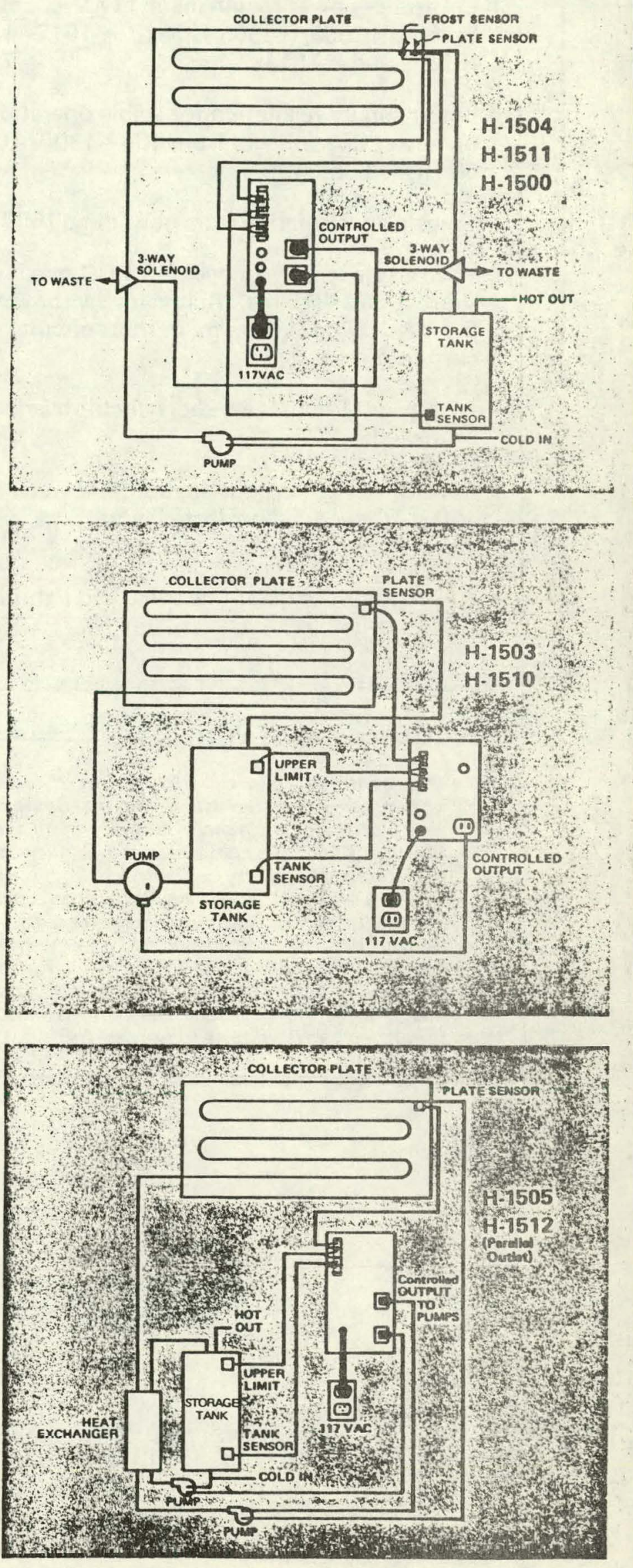




\section{SPECIFICATIONS:}

- Controller power requirement $117 \mathrm{VAC}, 60 \mathrm{HZ}$ $\mathrm{H}-1500, \mathrm{H}-1503, \mathrm{H}-1505, \mathrm{H}-1510, \mathrm{H}-1512-4$ watts $\mathrm{H}-1504$ and $\mathrm{H}-1511$

-7 watts

- Power supply regulation for stable operation on power line voltages from 105-130 VAC, $60 \mathrm{HZ}$ (all units).

- Transformer isolation from power line 1600VAC. and

- Thermistor sensor voltages 8.3 VDC maximum short circuit $4.15 \mathrm{ma}$. Actovator sensor voltages $5.1 \mathrm{VAC}, 60 \mathrm{HZ}$. Maximum short circuit current 4 ma.

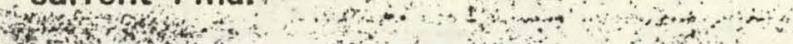

All sensor terminals are short circuit overload protected.

howhon

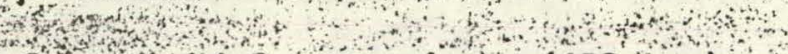

- Controlled A.C. output $4 \mathrm{amp}$. (480 watt) at 120 VAC overload protected with 4 amp. 3 AG fuse.

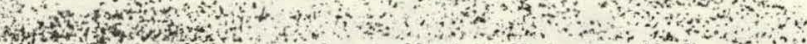
All units have varistor line spike and lightning protection.
- Fixflo controllers $5^{\circ} \mathrm{F}$ differential to turn on.

- Variflo controllers $3-4^{\circ} \mathrm{F}$ start with $20^{\circ} \mathrm{F}$ span to full on.

- Indicator lamp solid state light emitting diode.

- Controller case durable phonolic thermo plastic with black anodized aluminum face plate and white epoxy silk-screen lettering. Case dimensions $6^{\prime \prime} \times 3^{1 / 4}{ }^{\prime \prime} \times 2 \frac{1}{4}$ ".

- Sensor case black anodized aluminum or nickel plated copper.

- All circuitry self-extinguishing epoxy encapsulated.

Shipping weight $-2 \mathrm{lbs}$.

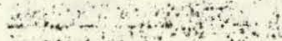

- All units Applied Research Laboratories approved. Test \#21588.

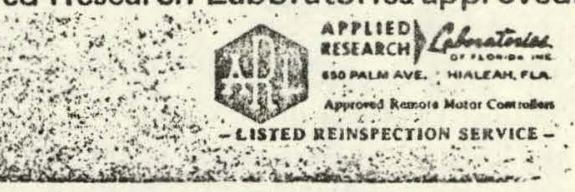

\begin{tabular}{l}
\hline Whis controller is warranted against defects in \\
workmanship or materials under normal use for one \\
year from date of purchase. Liability in all events \\
is limited to purchase price paid and liability under \\
the aforesaid warranty is limited to replacing or \\
repairing any part or parts which are defective in \\
material or workmanship and are returned to our \\
factory, shipping cost prepaid. No other warranty, \\
expressed or implied, nor representation of mer- \\
chantability or of fitness for a particular purpose, \\
except as set forth in this warranty, is made or \\
authorized by Hawthorne Industries, Inc.
\end{tabular}

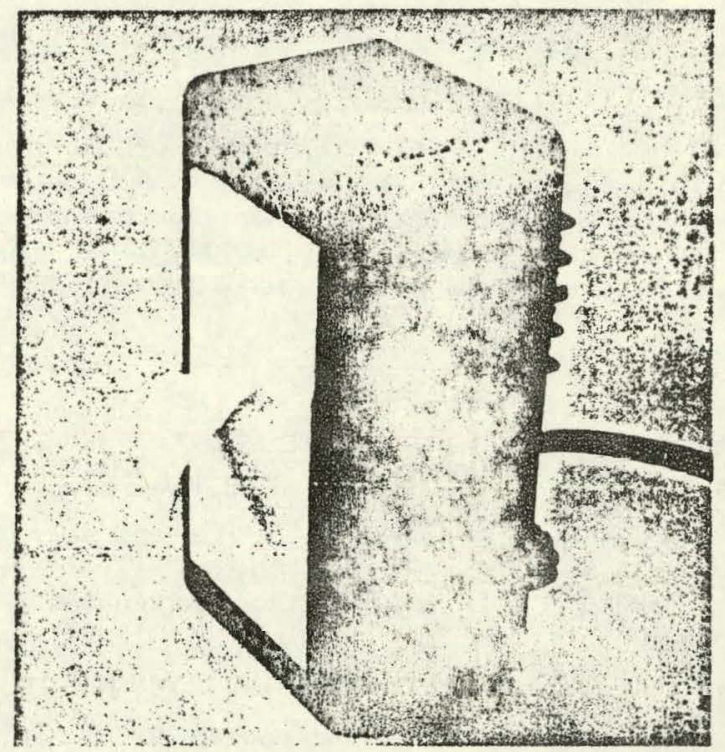

Extremely strong, pressure-sensitive foam tape on the back of the controller case provides for instant mounting of the unit. 

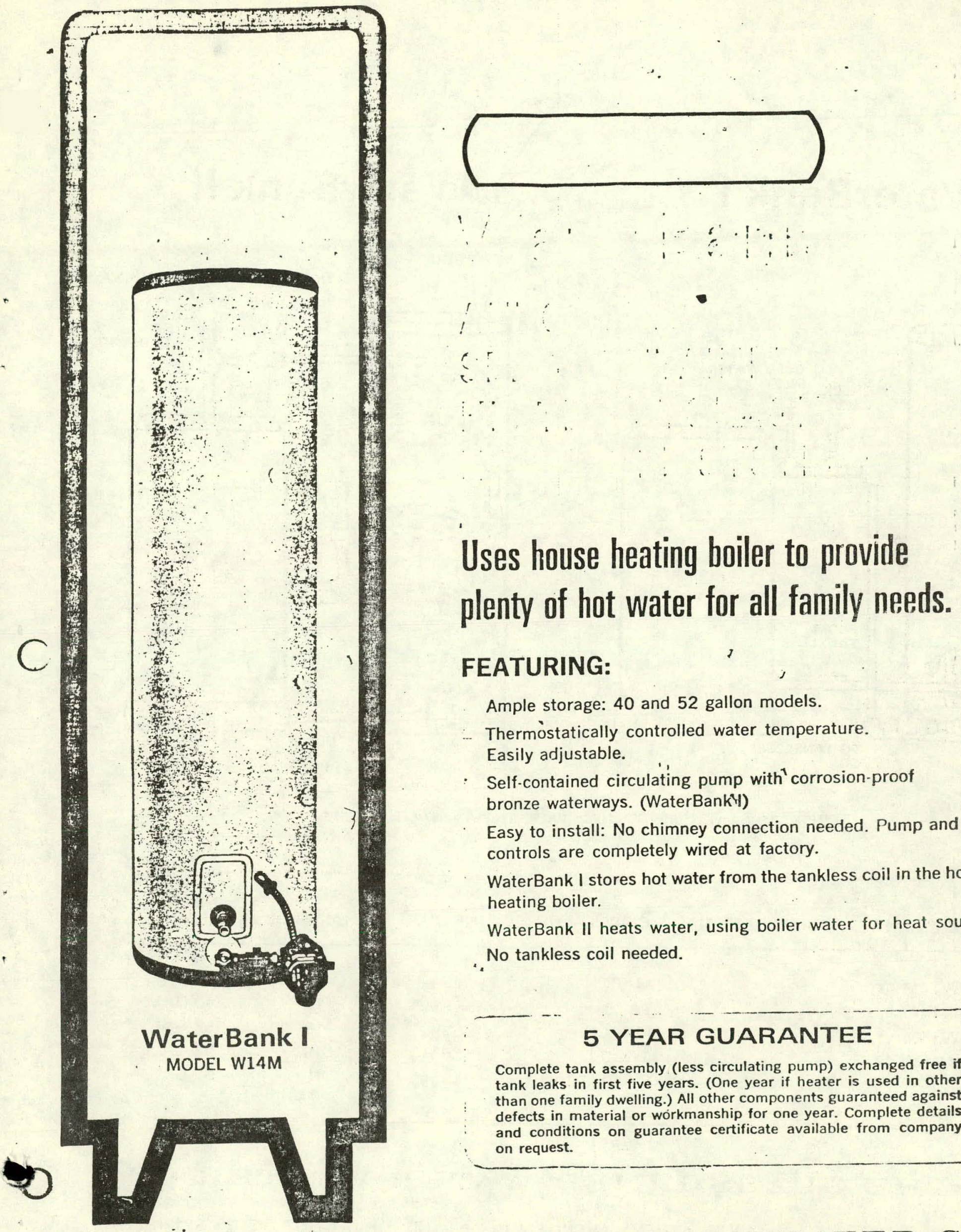

\section{FEATURING:}

Ample storage: 40 and 52 gallon models.

Thermostatically controlled water temperature.

Easily adjustable.

- Self-contained circulating pump with' corrosion-proof bronze waterways. (WaterBank'y)

Easy to install: No chimney connection needed. Pump and controls are completely wired at factory.

WaterBank I stores hot water from the tankless coil in the house heating boiler.

WaterBank II heats water, using boiler water for heat source.

No tankless coil needed. 


\section{WaterBank I}

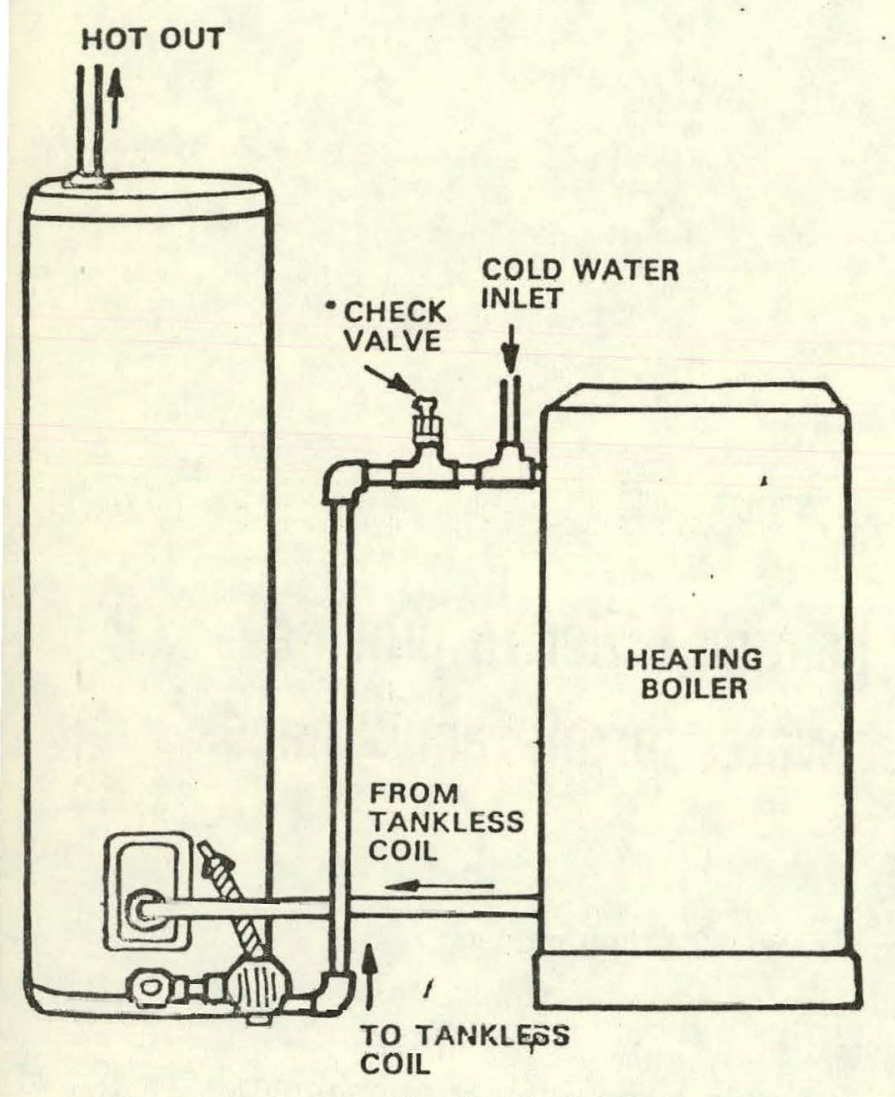

WaterBank II .

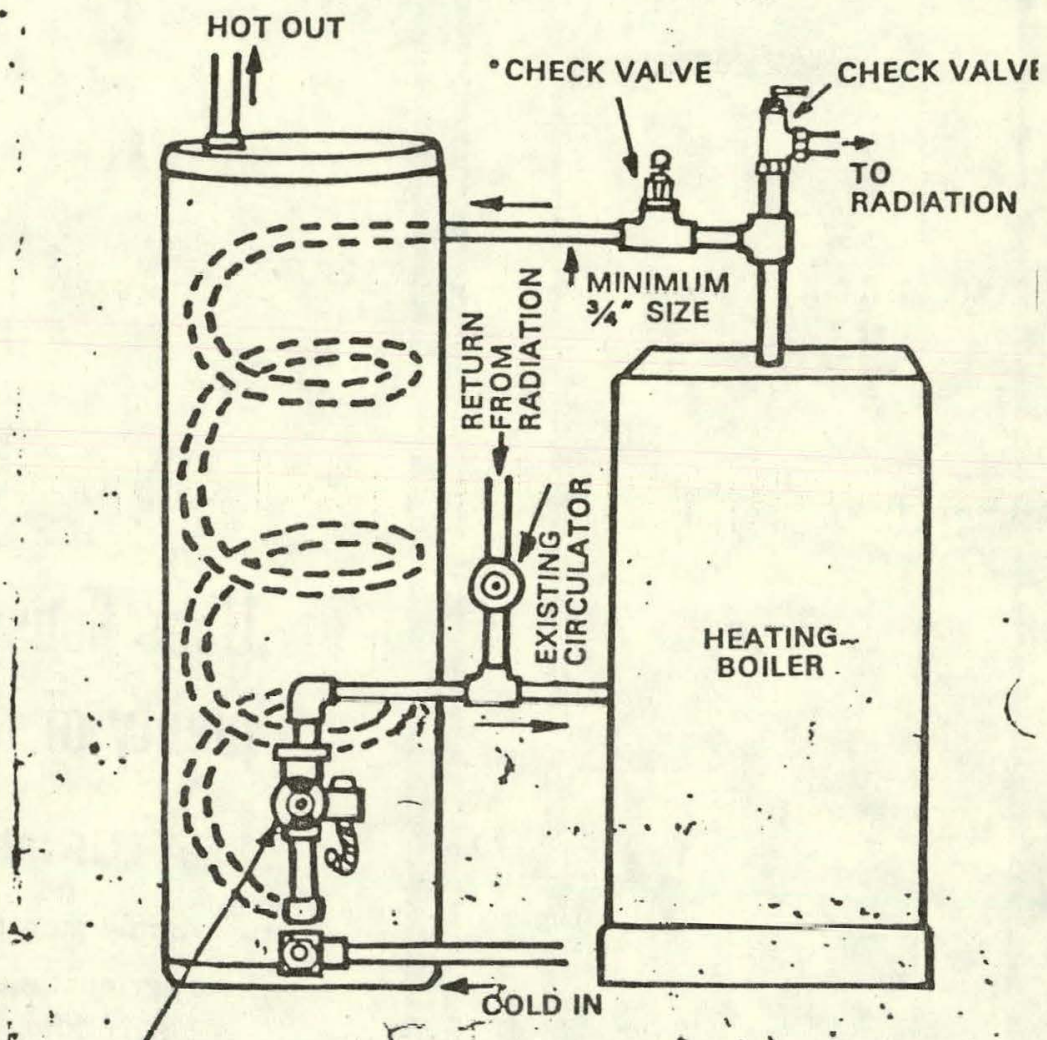

- USE SPECIAL WATERBANK CHECK VALVE TO PREVENT CHATTERING.

WATERBANK HIGH HEAD *

I. $\quad \because \quad$ C.IRCULATOR

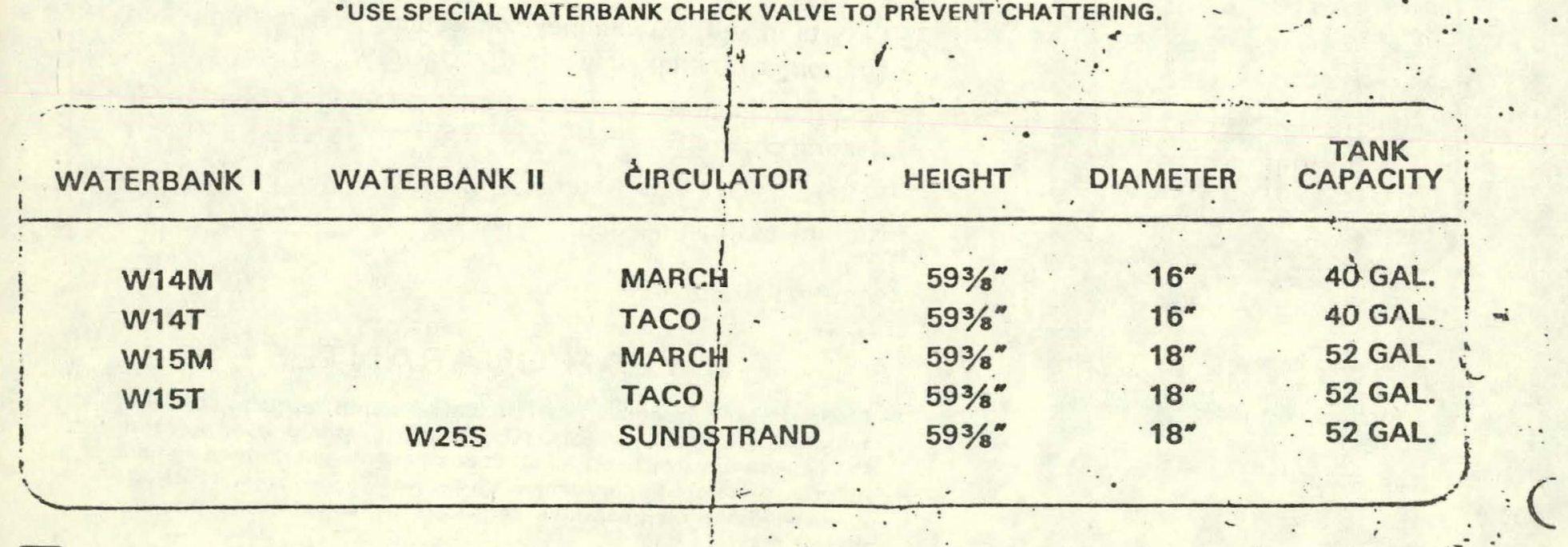

